\title{
USDA
}

United States

Department of

Agriculture

Protecting

Agricultural

Marketing

Service

Transportation and

Perishable Foods

During Transport by Truck

Marketing Programs

Handbook

Number 669

September 1995

Reprinted J uly 2008

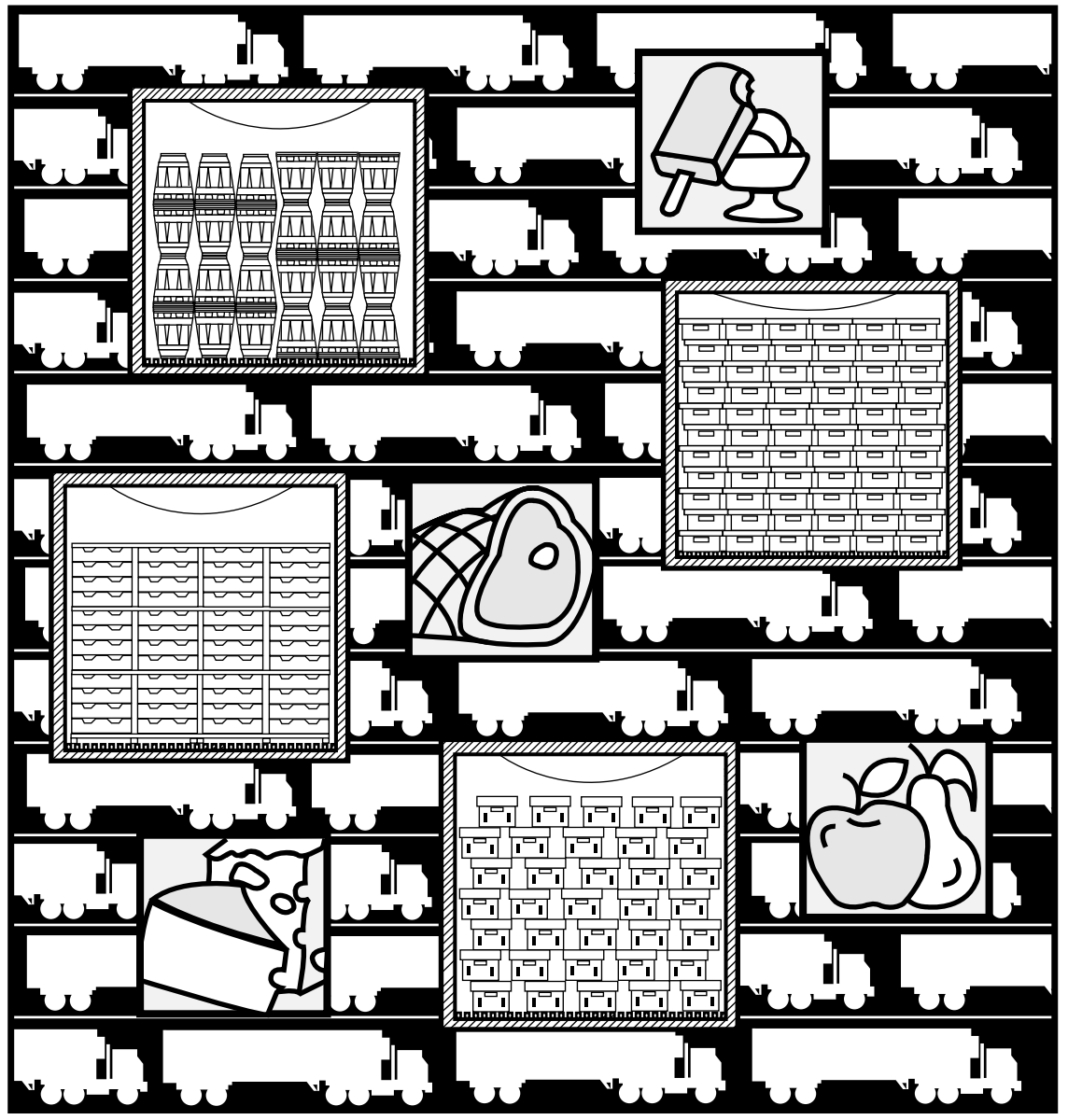




\section{Protecting Perishable Foods During Transport by Truck}

by B. Hunt Ashby

Agricultural Marketing Service

Transportation and Marketing Programs

September 1995

Reprinted July 2008

The U.S. Department of Agriculture (USDA) prohibits discrimination in all its programs and activities on the basis of race, color, national origin, age, disability, and where applicable, sex, marital status, familial status, parental status, religion, sexual orientation, genetic information, political beliefs, reprisal, or because all or part of an individual's income is derived from any public assistance program. (Not all prohibited bases apply to all programs.) Persons with disabilities who require alternative means for communication of program information (Braille, large print, audiotape, etc.) should contact USDA's TARGET Center at (202) 720-2600 (voice and TDD).

To file a complaint of discrimination, write to USDA, Director, Office of Civil Rights, 1400 Independence Avenue, S.W., Washington, D.C. 20250-9410, or call (800) 795-3272 (voice) or (202) 720-6382 (TDD). USDA is an equal opportunity provider and employer. 



\section{Contents}

\section{Introduction}

\section{Important Factors in Protection of Perishable Foods}

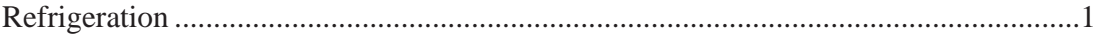

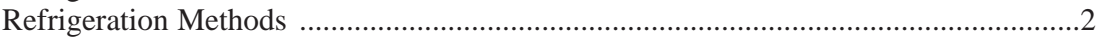

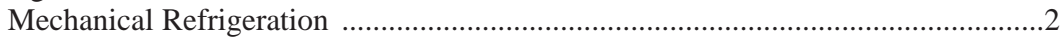

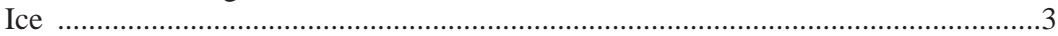

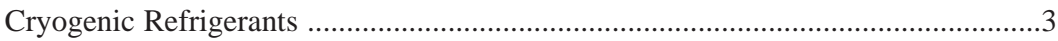

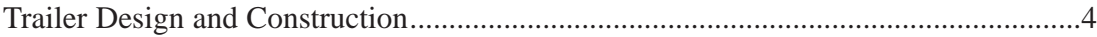

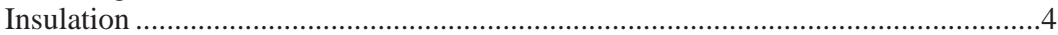

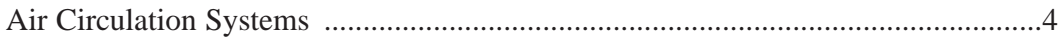

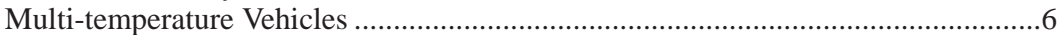

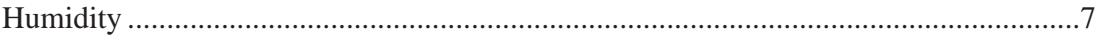

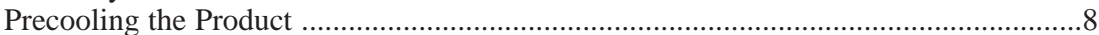

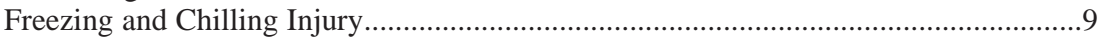

Controlled and Modified Atmospheres............................................................................

\section{Preparation for Loading}

Adequacy of Equipment

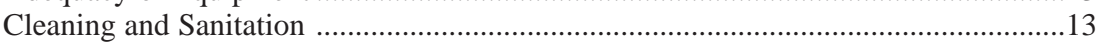

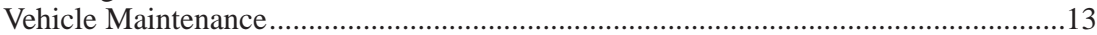

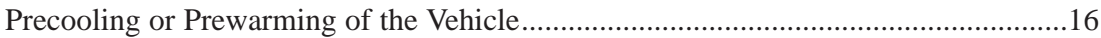

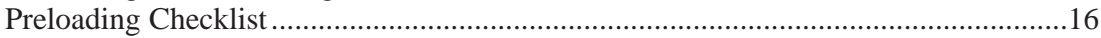

\section{Loading Considerations}

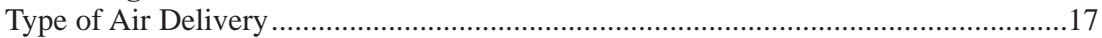

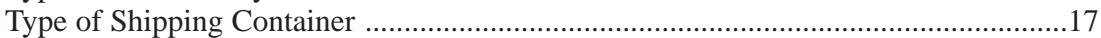

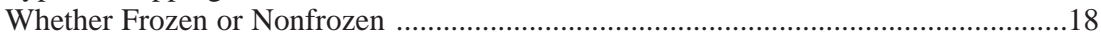

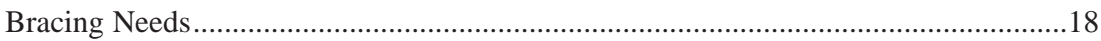

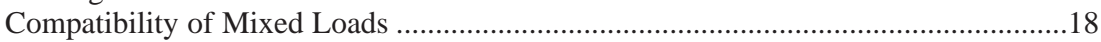

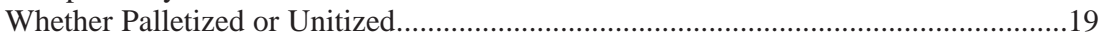

Length of Transit Period .......................................................................................... 19

\section{Loading and Load Patterns}

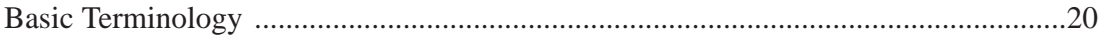

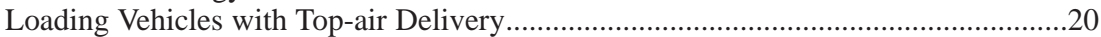

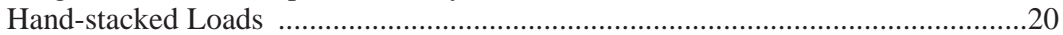

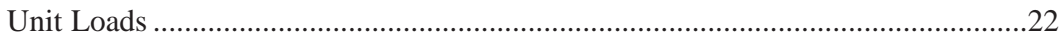

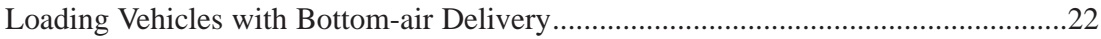

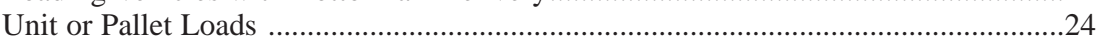

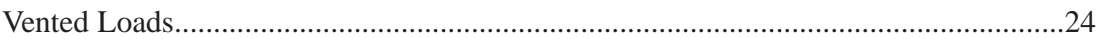

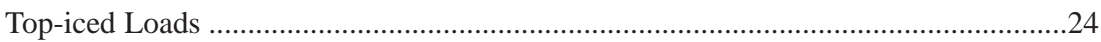

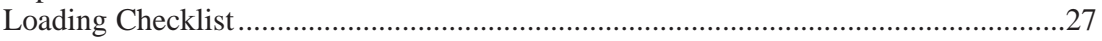

\section{Individual Commodity Requirements}

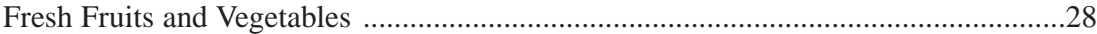

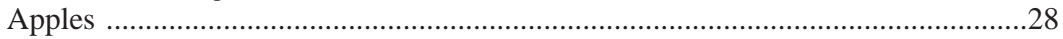

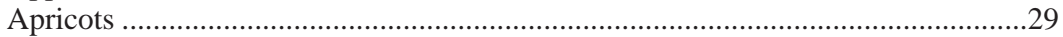




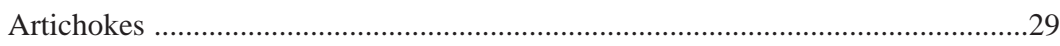

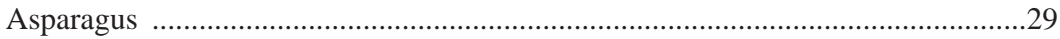

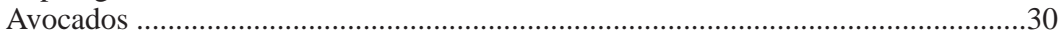

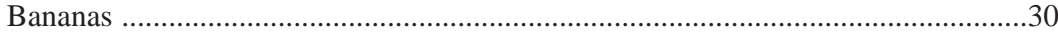

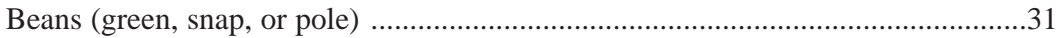

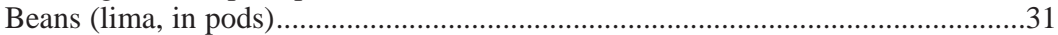

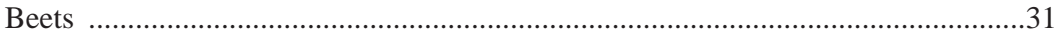

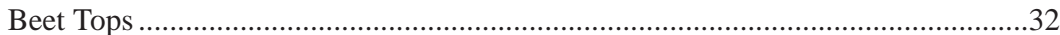

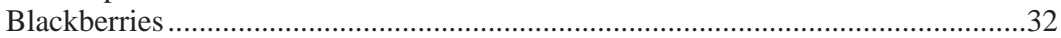

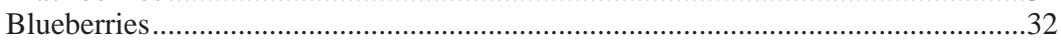

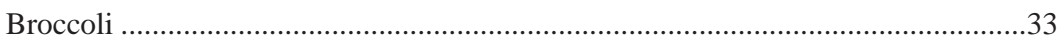

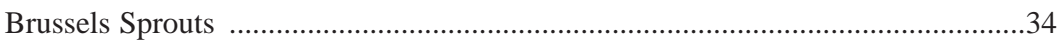

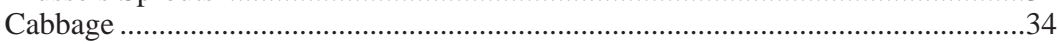

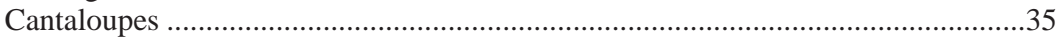

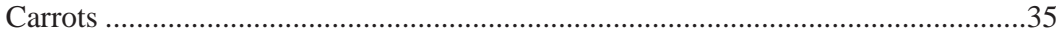

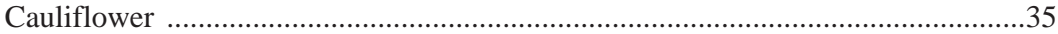

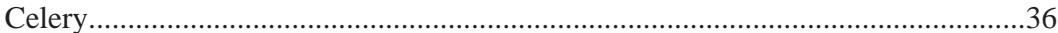

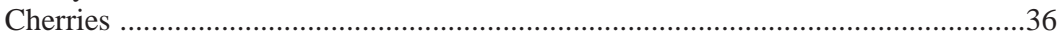

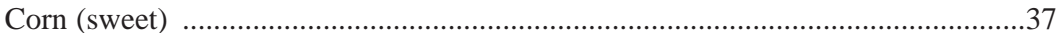

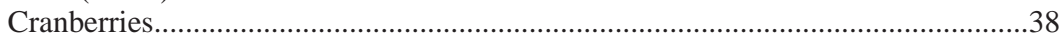

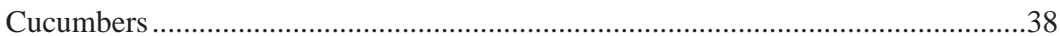

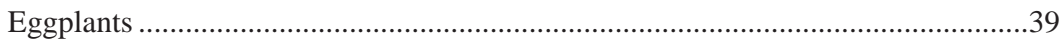

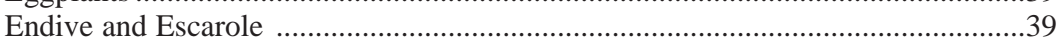

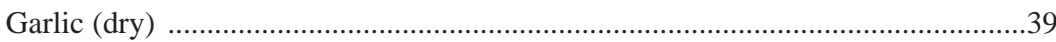

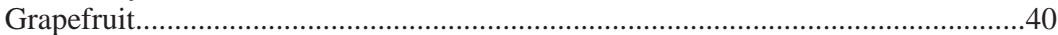

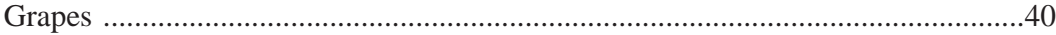

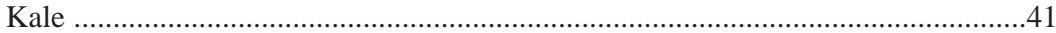

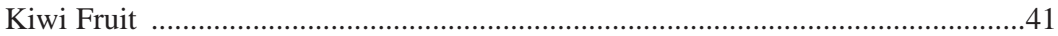

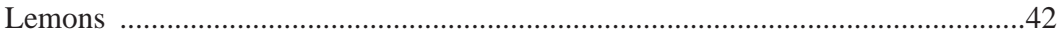

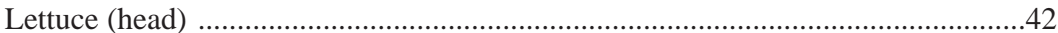

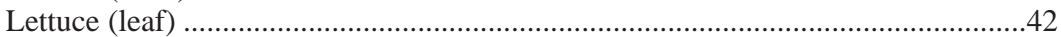

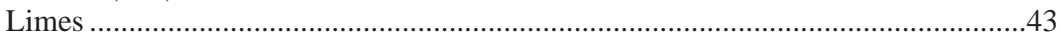

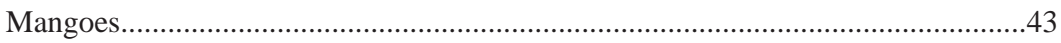

Melons (Honeydew, Casaba, Crenshaw, Persian) ………………………………......4

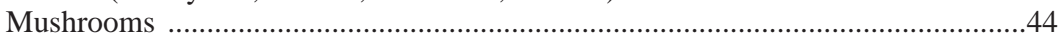

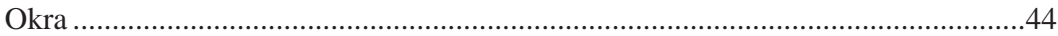

Onions (green), Shallots, and Leeks ....................................................................45

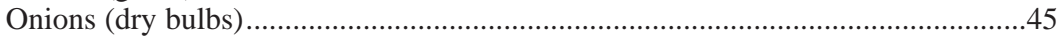

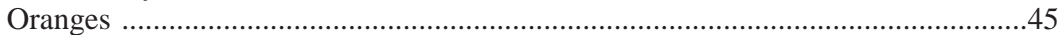

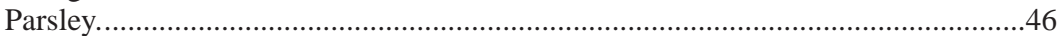

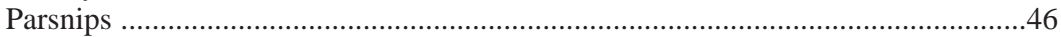

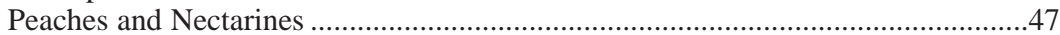

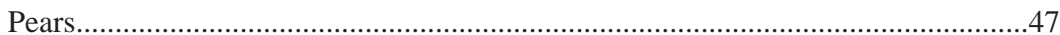

Peas (green and snow peas in pods) ………………………………………......47

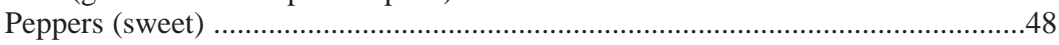

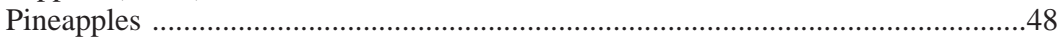

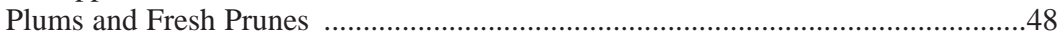

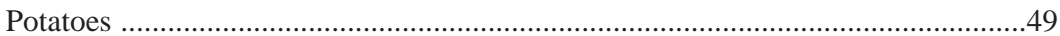

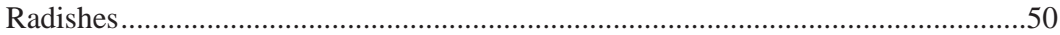

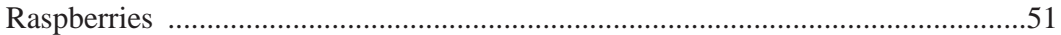

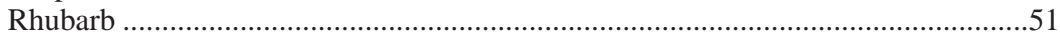

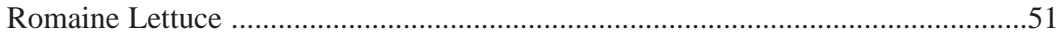

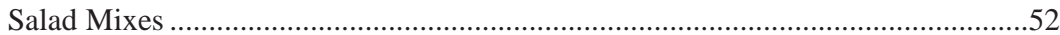


Spinach

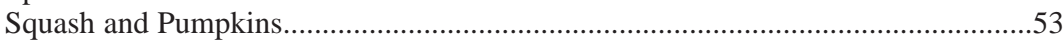

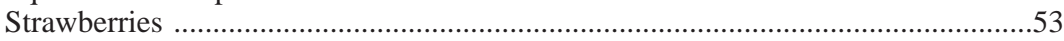

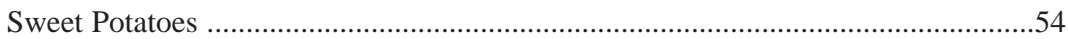

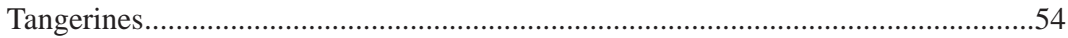

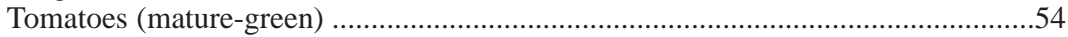

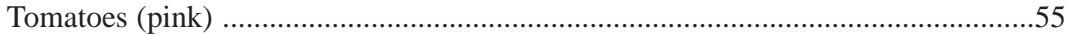

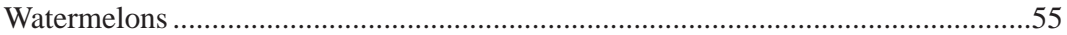

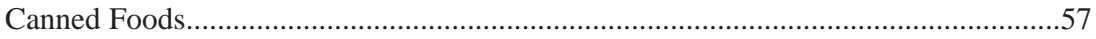

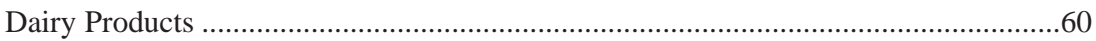

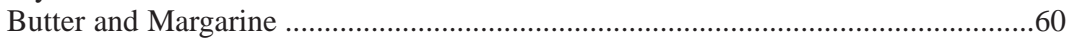

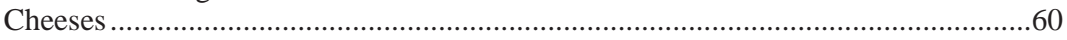

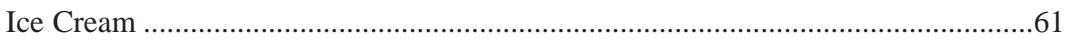

Fresh and Cured Meat and Fresh Seafood........................................................62

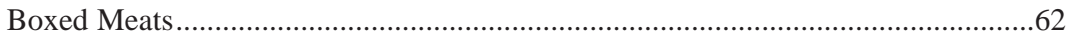

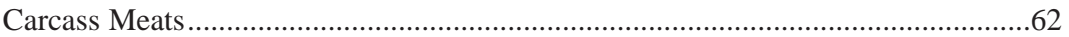

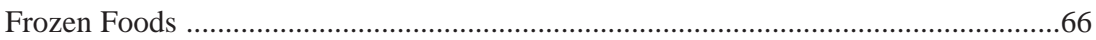

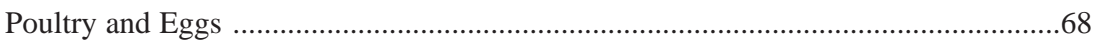

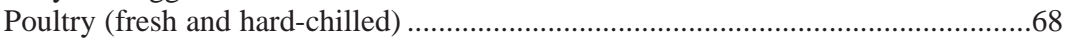

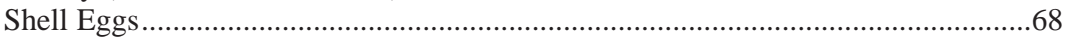

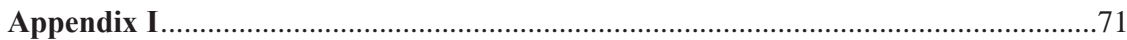

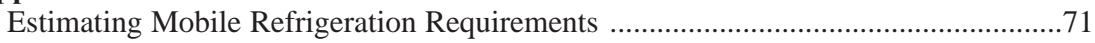

Sample Refrigeration Requirement Calculation .....................................................76

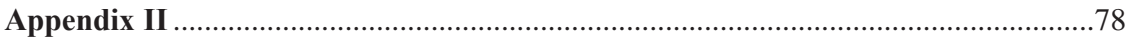

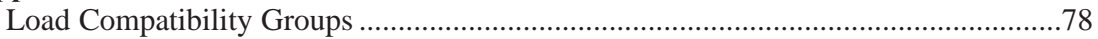

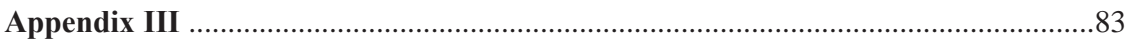

Recommended Protective Services for Perishable Foods During Transit....................83

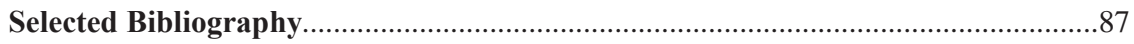

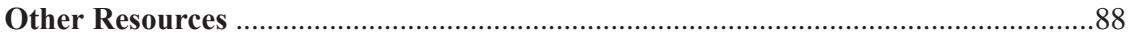




\section{List of Tables}

Table 1. - Heat Absorption Characteristics of Certain Refrigeration Mediums

Table 2. - Sensitivity of Some Fruits and Vegetables to Freezing

Table 3. - Some Fruits and Vegetables Subject to Chilling Injury at Above-freezing Temperatures

Table 4. - Freezing Temperatures of Selected Canned Foods

Table 5. - Ideal Temperature Ranges for Transporting Common Types of Cheeses

Table 6. - Recommended Temperatures and Humidities for Protecting Selected Fresh, Cured, and Processed Meat and Seafood Products During Transit

Table I-1.- Specific Heat Above and Below Freezing for Certain Perishable Products

Table I-2.- Approximate Amount of Respiration Heat Produced by Certain Fruits and Vegetables at the Specific Temperatures 


\section{List of Figures}

1. Depletion of sucrose or sugar in sweet corn with increase in holding temperature.

2. Pathways of air in a trailer with a top-air delivery system.

3. Pathways of air in a trailer with a bottom-air delivery system.

4. Features essential for maintaining the critical airflow chain in trailers with top-air delivery.

5. Effect of different floor configurations on return-air space under the load.

6. A typical multi-temperature mechanically refrigerated trailer.

7. Methods of loading to reduce contact of products with walls and to reduce the chance of freezing or chilling injury in extremely cold weather: (a) crosswise-offset stacking of boxes or crates, (b) pyramid stacking of bagged products, and (c) center-loading of palletized loads.

8. Location of NPLA/RTF certification plates and decals which provide information on refrigeration rating and optional equipment on refrigerated trailers at time of manufacture.

9. Dimensional view of a load in a truck semi-trailer showing arrangements of containers in rows, stacks, and layers.

10. A typical airflow loading pattern for commodities packed in fiberboard boxes: (a) longitudinal view, (b) header stack, and (c) rear view of all other stacks.

11. Rear view of an airflow loading pattern modified for wirebound crates.

12. End and overhead views of basic pallet or unit load patterns in a semi-trailer: (a) airflow, (b) center-loaded, (c) wall-loaded, (d) off-set against walls, and (e) pinwheel. (Note: Pallets used in pinwheel patterns must be 4-way or air flow under the load will be blocked.)

13. Effect of different unit load patterns on the percentage of cartons contacting the floor and walls in a typical load of a perishable product.

14. Example of strapping and corner boards on a unit load. 
15. Example of a method for bracing a load at the rear doors.

16. Rear view of a stacking pattern with horizontal wood stabilizing strips for top-iced loads in wirebound crates (shown) or waxed fiberboard boxes.

17. A palletized load of strawberries, center-loaded. (Note: Each pallet load is enclosed in an airtight plastic bag injected with a modified atmosphere.)

18. A mixed palletized load of celery and green onions loaded in a unit load airflow pattern.

19. Side (a) and end (b) views of a mixed load of hanging forequarters and hindquarters of beef.

20. A palletized load of eggs. Note the stretch film around the pallet loads at the rear door area where road shock is greatest. 


\section{Preface}

This is a revision of handbook No. 669 published in 1987. It superseded Agriculture Handbook No. 105, "Protecting Perishable Foods During Transport by Motortruck," first published in 1956 and revised in 1970. These handbooks have been extremely popular, and tens of thousands of copies have been distributed worldwide.

This updated edition reflects the dynamic changes and innovations in the handling and transportation of perishable foods. Some of these are the rapid change from handstacked loads to unitized loads on pallets and slipsheets, the use of microprocessors for more efficient refrigeration, and the use of satellites to monitor and control the performance of refrigerated vehicles during transit.

Many individuals and organizations provided information or other assistance in revising this handbook. Special recognition goes to W.L. Craig of USDA's Agricultural Marketing Service for preparing the illustrations, and to L.A. Risse of USDA's Agricultural Research Service for reviewing this publication. A great deal of the information on recommended holding requirements for fresh fruits and vegetables is from USDA Handbook No. 66 The Commercial Storage of Fruits, Vegetables, and Florist and Nursery Stocks, cited in the bibliography. 



\section{Important Factors in Protection of Perishable Foods}

\section{Refrigeration}

The object of refrigerating food products is to maintain quality and prolong shelf life by keeping the product temperature at the point where metabolic and microbial deterioration are minimized. Maintaining the desired or ideal holding temperature is a major factor in protecting perishable foods against quality loss during storage and distribution. Quality loss is a function of both time and temperature abuse. Abuse is additive and, even for short periods of time during loading, transit, and unloading, may cause a considerable amount of quality loss by the time the product reaches its destination.

Abuse can result from temperatures that are either too high or too low. For example, high temperatures cause loss of vitamin $\mathrm{C}$ in asparagus, and sugar or sucrose depletion in fresh sweet corn (figure 1). Low temperatures can cause chilling injury to fresh fruits and vegetables. This may not show up until the product is at the retail store or on the consumer's table, where failure to ripen properly, off-flavors, discoloration, pitting, and other signs of poor quality may be evident.

Refrigeration removes excess heat and provides temperature control for food products in transport vehicles. Heat is a positive and measurable form of energy that always radiates or flows toward the cold or refrigeration source.

In the United States, heat is measured in British thermal units (Btu). The Btu is defined as the amount of heat required to raise the

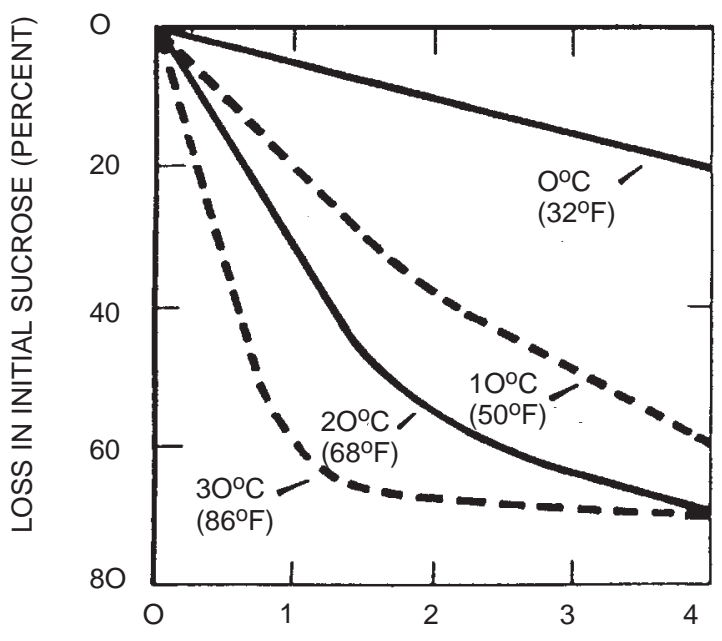

DAYS IN STORAGE

Figure 1. Depletion of 
temperature of $1 \mathrm{lb}(0.45 \mathrm{~kg})$ of water $1^{\circ} \mathrm{F}$ $\left(0.56^{\circ} \mathrm{C}\right)$. A metric equivalent of the Btu is the kilojoule $(\mathrm{kj})$ or $1 \mathrm{Btu}=1.005 \mathrm{kj}$.

A truck refrigeration system must have sufficient capacity to remove heat generated by the sources described below.

Residual heat from the air inside the trailer, and heat in the insulation and inner lining of the trailer.

Exterior heat conducted through the floor, walls, and ceiling. It is dependent on the temperature differential between the inside and outside air, type and thickness of insulation, and the area of the conducting surfaces. Solar radiation will increase the temperature of outside surfaces where the trailer body is exposed to the sun.

Infiltration heat from warm outside air through small holes, cracks, and door seals. It increases refrigeration requirements.

Excess heat in the commodity above the desired transit temperature.

Heat of respiration generated by all fresh fruits and vegetables. Some products, such as asparagus, corn, and strawberries, respire at a higher rate than other products, such as apples, oranges, and potatoes. The rate at which respiration heat is generated also varies with the temperature of the product. It is considerably less at temperatures near freezing than at normal harvest temperatures. Table I-1 in appendix I gives the amount of heat produced by various fruits and vegetables at given temperatures.

\section{Refrigeration Methods}

In the past, several methods of refrigerating trucks have been used. These include ice, ice and salt, dry ice, hold-over plate systems, cryogenic systems, and mechanical refrigeration. Today, however, mechanical refrigeration is the predominant type. Trailers refrigerated with cryogenic refrigerants, usually liquid carbon dioxide $\left(\mathrm{CO}_{2}\right)$ or nitrogen $\left(\mathrm{N}_{2}\right)$, have been used to some extent over the past three decades, but they are not as popular as trailers refrigerated mechanically.

\section{Mechanical Refrigeration}

Mechanical refrigeration operates by absorbing heat at one point and dispensing it at another. This is accomplished by circulating a refrigerant between two points. The refrigerant picks up heat through a coil (evaporator) inside the cargo space and discharges it through another coil (condenser) on the outside. The refrigerant is circulated through the system by a compressor, which is driven by a gasoline, diesel, or electrical motor.

On highway trailers most mechanical refrigeration units are "nosemounted," with the engine, condenser, and other accessories on the outside front of the trailer, and the evaporator coil and air fans directly inside.

Refrigerated containers built for intermodal service have the compressor engine and condenser coil recessed flush with the outside surfaces in the front section of the containers. This allows the containers to be evenly stacked aboard rail cars or containerships.

Mechanical refrigeration units are rated according to their ability to remove or produce heat. The cooling capacity of a unit is expressed in the number of Btu's per hour a unit can remove at $100^{\circ} \mathrm{F}\left(38^{\circ} \mathrm{C}\right)$ outside and at $35^{\circ} \mathrm{F}\left(1.7^{\circ} \mathrm{C}\right), 0^{\circ} \mathrm{F}\left(-18^{\circ} \mathrm{C}\right)$, and $-20^{\circ} \mathrm{F}$ $\left(-29^{\circ} \mathrm{C}\right)$ inside trailer temperature. Heating capacity of the unit is measured in Btu's per hour, while inside trailer temperatures are $65^{\circ} \mathrm{F}\left(18^{\circ} \mathrm{C}\right)$ or $35^{\circ} \mathrm{F}\left(1^{\circ} \mathrm{C}\right)$ under $0^{\circ} \mathrm{F}$ $\left(-18^{\circ} \mathrm{C}\right)$ ambient. (The rating procedure is based on the Air-Conditioning and Refrigeration Institute's (ARI) Standard 1110.) The refrigeration capacity needed for a particular load depends on the desired product temperature, the amount of vehicle insulation, ambient temperatures, product temperature at loading, amount of product respiration heat, and the extra capacity (reserve) desired.

Today's refrigeration units are equipped with microprocessors programmed to control the operation of the unit so that both refrigeration and fuel efficiency are maximized. Air temperatures are monitored at the discharge and return locations, and adjusted to demand for refrigeration at the thermostat set-point. This reduces temperature spread around the thermostat set-point, which reduces dehydration 
and maintains product quality. The microprocessors also can be programmed to provide diagnostic tests and automatically run through a pretripping mode. Some of the microprocessors are radio-equipped and may be contacted via satellite to monitor performance of the refrigeration unit, pinpoint geographic location of the trailer, monitor product temperatures, and perform other functions.

\section{Ice}

Ice is a good absorber of heat (table 1) and also helps to maintain humidity in loads of fresh produce. The main drawbacks for ice are its weight, which cuts down on the payload; the difficulty and expense of replenishing ice enroute; the need for water-resistant packaging when applied as top-ice; and the damage some fresh fruit and vegetables incur when contacted by ice.

Crushed or slush-ice blown over the top of produce loads is used to refrigerate and maintain high levels of humidity for certain products. This is known as "top-icing." Some shippers may apply the crushed ice or slushice to individual pallet loads or in individual boxes of product (package-ice) before loading.

\section{Cryogenic Refrigerants}

Cryogenic (low-temperature) refrigerating systems, which use liquid or solid carbon dioxide $\left(\mathrm{CO}_{2}\right)$ or liquid nitrogen $\left(\mathrm{N}_{2}\right)$, are available for highway trailers. They are used primarily in delivery operations requiring 1-day or less transit time, since supplies of liquid cryogens are not available at truck stops. Advantages of the cryogenic systems are that they have fewer moving parts to maintain and replace, and also allow quick recovery of thermostat set-point temperature after delivery stops.

Liquid cryogenic systems usually operate by having the liquid refrigerant in pressurized tanks. A temperature-sensing element inside the trailer activates a controller which releases the liquid refrigerant through a spray nozzle at the ceiling of the trailer. The liquid $\mathrm{CO}_{2}$ or $\mathrm{N}_{2}$ spray flashes into gas as it hits the warmer air in the trailer, absorbing the heat. When the desired temperature is reached, the sensing element sends a signal to the controller to shut off the flow of refrigerant. In another type system, the liquid $\mathrm{CO}_{2}$ is circulated through a coil or plate heat exchanger and the vaporized gas vented outside. A third type of system stores $\mathrm{CO}_{2}$ snow in a full length ceiling bunker and cools as the snow melts.

WARNING: Allow adequate time for replenishment of oxygen before entering a vehicle refrigerated by $\mathrm{CO}_{2}$ or $\mathrm{N}_{2}$. Workers

Table 1. Heat Absorption Characteristics of Various Refrigeration Mediums

\begin{tabular}{|c|c|c|}
\hline Medium & $\begin{array}{l}\text { Amount of } \\
\text { At or } \\
\text { Above Freezing1 }\end{array}$ & $\begin{array}{l}\text { Absorbed } \\
\text { Below Freezing }\end{array}$ \\
\hline$\ldots \ldots \ldots$ & $\begin{array}{cc} & \text { Btu's/lb } \\
\ldots & 144\end{array}$ & Btu's/lb \\
\hline $\begin{array}{l}\text { Carbon Dioxide }\left(\mathrm{CO}_{2}\right) \\
\quad \text { Liquid } \ldots \ldots \ldots \ldots \ldots \ldots \ldots \ldots \ldots \ldots \ldots \ldots \ldots \ldots \ldots \ldots \ldots \ldots \ldots \ldots \ldots \ldots \ldots\end{array}$ & $\begin{array}{l}130 \\
240\end{array}$ & 120 \\
\hline $\begin{array}{l}\text { Nitrogen }\left(\mathrm{N}_{2}\right) \\
\quad \text { Liquid } \ldots \ldots \ldots \ldots \ldots \ldots \ldots \ldots \ldots \ldots \ldots \ldots \ldots \ldots \ldots \ldots \ldots\end{array}$ & 175 & 165 \\
\hline
\end{tabular}

${ }^{1}$ Freezing $=32^{\circ} \mathrm{F}\left(0^{\circ} \mathrm{C}\right)$ 
entering a vehicle with concentrations of $\mathrm{CO}_{2}$ or $\mathrm{N}_{2}$ gases may be rendered unconscious by the lack of oxygen.

Also, high concentrations of cryogenic refrigerant gases (generally above 20 percent) may have an adverse effect on fresh produce. Most fresh fruits and vegetables will eventually suffocate in a 100-percent $\mathrm{N}_{2}$ atmosphere, although many products will tolerate high levels of $\mathrm{N}_{2}$ for a few days without injury. High percentages of $\mathrm{CO}_{2}$ gas in the atmosphere may cause off-flavors, off-colors, and physiological disorders in fresh produce. On the other hand, moderate concentrations of this gas are successfully used to retard decay and ripening of fruits and vegetables during transit and storage. Generally, $\mathrm{N}_{2}$ atmospheres are not harmful to food products, and $\mathrm{CO}_{2}$ atmospheres help retard microbial growth on fresh meat and meat products (see "Controlled and Modified Atmospheres"). Neither $\mathrm{CO}_{2}$ nor $\mathrm{N}_{2}$ gas will harm frozen foods.

Solid $\mathrm{CO}_{2}$ (dry ice) may be in the form of blocks, snow, or pellets, all of which are used as refrigeration mediums in transport vehicles. The most frequent use of solid $\mathrm{CO}_{2}$ is in frozen food and ice cream delivery trucks. Solid $\mathrm{CO}_{2}$ may be used as an emergency refrigerant in the event of mechanical unit breakdown in vehicles hauling frozen products. Dry ice changes into gas at $-109^{\circ} \mathrm{F}\left(-78.3^{\circ} \mathrm{C}\right)$. Table 1 gives the heat absorption characteristics of these mediums.

\section{Trailer Design and Construction}

\section{Insulation}

Vehicles used to transport perishable food products should be well insulated to retard the flow of heat through their walls. Insulating quality is measurable, and the industry standard is the $\mathrm{U}$ factor (coefficient of heat transfer through a trailer body). The lower the $\mathrm{U}$ factor, the better the insulation.

Plastic foams are the predominant material used in insulating refrigerated vehicles because they offer a low U factor, are lightweight, waterproof, and noncorrosive. Additional insulation advantages are obtained when the plastic is "foamed in place" during manufacture. This procedure fills in cracks and crevices that would otherwise allow air leakage.

Insulation quality is further enhanced by the use of highly polished steel or aluminum exterior skin which reflects heat rays from the sun or road surfaces. There also are reflective paints for refrigerated vehicles. The reflecting effect of any material is diminished, however, if the outside of the vehicle is not kept clean.

High-quality insulation will be of little value if door seals are leaking. Door seals must be properly fitted and in good repair.

\section{Air Circulation Systems}

Air circulation is one of the most important factors in protecting refrigerated loads of perishable foods. Refrigeration capabilities are meaningless if the refrigerated air is not properly circulated to maintain product temperature.

Air circulation carries product heat and the heat which penetrates the walls, floors, and ceiling of the trailer to the refrigeration unit where it can be removed. Heated air may be circulated to keep fresh produce from incurring chilling or freezing injury. Air circulation also is important to ensure uniform temperatures throughout the load.

There are two major methods of circulating air in refrigerated vehicles. Overhead, or top-air, delivery is the conventional method. The second method is bottom-air delivery, which has been employed extensively in seagoing van containers for several decades, but only to a limited extent in highway trailers. Figures 2 and 3 illustrate the pathways of airflow in top- and bottom-air delivery trailers respectively.

\section{Top-air delivery}

In trailers with top-air delivery, air circulation and subsequent control of load temperatures are enhanced by the construction features below.

Ceiling ducts to direct the air from the blower to the rear of the trailer. The Nation- 


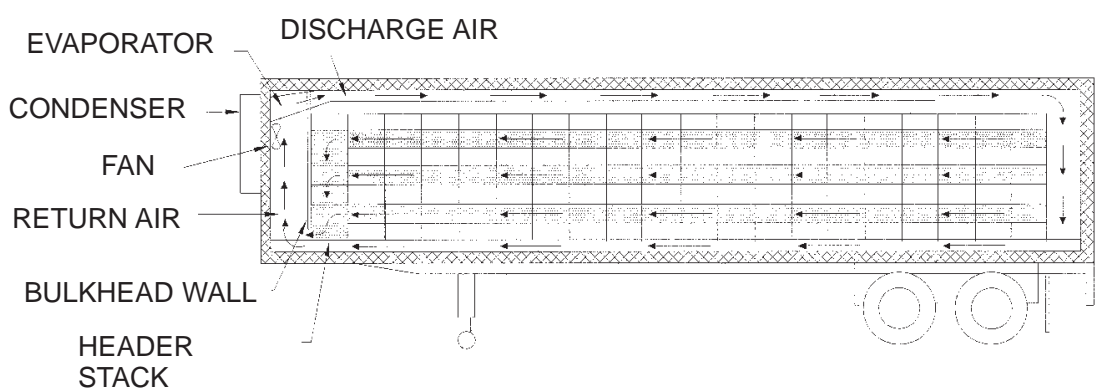

Figure 2.

Pathways of air in a

trailer with a top-air

delivery system.

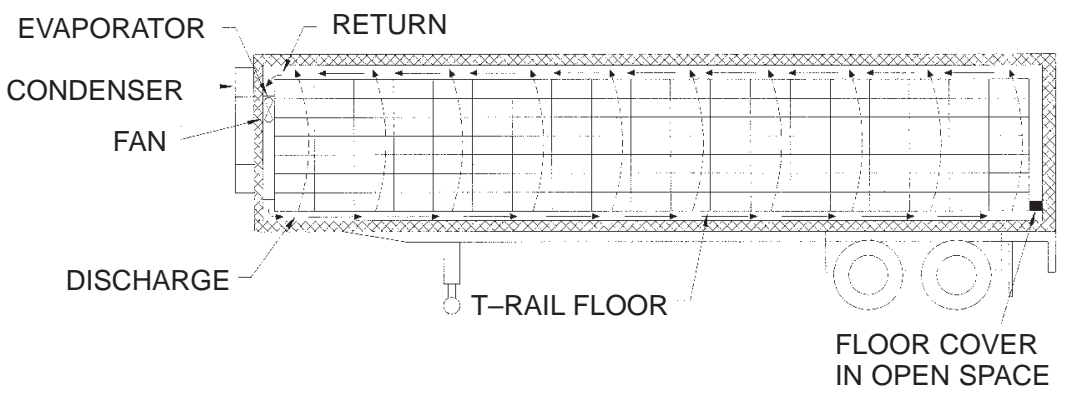

Figure 3.

Pathways of air in a

trailer with a bottom-air

delivery system.

al Perishable Logistics Association/ Refrigerated Transportation Foundation

(NPLA/RTF), a non-profit association of refrigeration equipment manufacturers and users, recommends that the air delivery chute provide a minimum of 240 square inches $\left(1548 \mathrm{~cm}^{2}\right)$ of cross-sectional area from the front of the vehicle to 10 to 15 feet ( 3 to $5 \mathrm{~m}$ ) from the rear. Progressive air spill provisions should be provided (except in the front 10 feet

(3 m) of length. A maximum load height line should be painted on the walls below the level of the bottom of the air delivery chute. Figure 4 illustrates features considered critical for maintaining the airflow pathways in a loaded refrigerated trailer.
Vertical channels or ribs on the inside of the rear doors and provisions for cross bracing at the rear of the load to prevent the blocking of air circulation between the load and the rear doors in the event of load shift.

High airflow floors that allow air to circulate under the load. About 240 square inches $\left(1,548 \mathrm{~cm}^{2}\right)$ of return air passage are needed for the average trailer's refrigeration fan to operate at 100 percent capacity. Figure 5 shows the effect of different floor configurations on return air space. The product should be loaded on pallets or floor racks when space for air circulation under the load is inadequate due to floor design. 
Ribbed sidewalls or spacers at least 1 inch thick $(3 \mathrm{~cm})$ to allow top airflow down the sides of the load. This reduces the amount of heat conducted across the walls to or from the product. Up to 20 percent of the top airflow should bleed off down the sidewalls.

A solid-front bulkhead designed to allow air free return to the refrigeration unit. If the air is blocked, the fan will turn, but not blow air. The NPLA/RTF recommends that the bulkhead be positioned a minimum of 3 inches $(8 \mathrm{~cm})$ from the front wall. A minimum of 6 inches $(15 \mathrm{~cm})$ of open space should be left between the bottom of the floor and the bottom edge of the bulkhead. The top side of the bulkhead should have 30 to 50 square inches (196 to $323 \mathrm{~cm}^{2}$ ) of open area to allow mixing of top and bottom air, and to allow some return air to the thermostat should the airflow be interrupted by improper loading or load shift. Bumpers or vertical strips should be attached to the open area at the bottom of the bulkhead wall to prevent the load from blocking air return to the blower under the bulkhead.

\section{Bottom-air delivery}

A few refrigerated highway trailers and most van containers used in overseas trade are equipped with bottom-air type delivery. In this type system, air is forced under and up through the load at a rate of 3,000 to 5,000 cubic feet per minute ( 85 to 142 cubic meters per second) and a static pressure of 1.5 to 3 inches $(0.37$ to $0.73 \mathrm{kPa})$ water. (The abbreviation $\mathrm{kPa}$ stands for kilopascal, a metric unit used to measure pressure.) The air returns to the refrigeration unit over the top of the load and through the top of the bulkhead (figure 3).

\section{Multi-temperature Vehicles}

Within the last decade there has been a rapid growth in the use of multi-temperature trailers for food delivery operations, especially

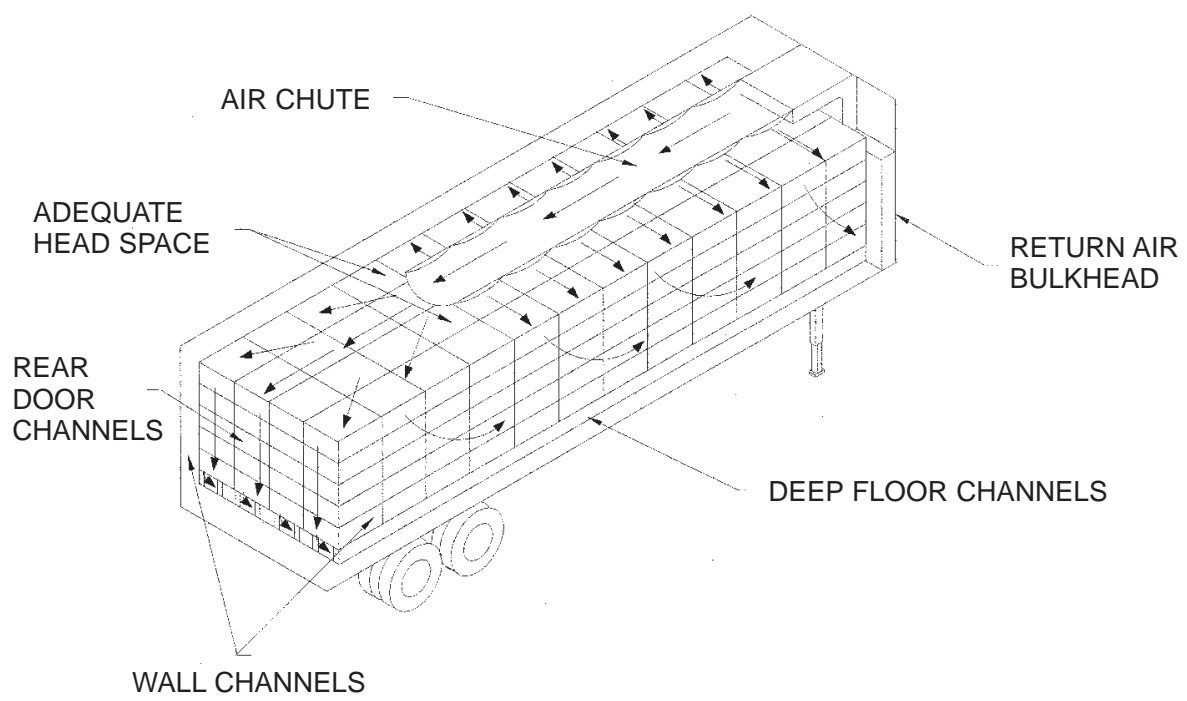

Figure 4.

Features essential for maintaining the critical airflow chain in trailers with top-air delivery. 


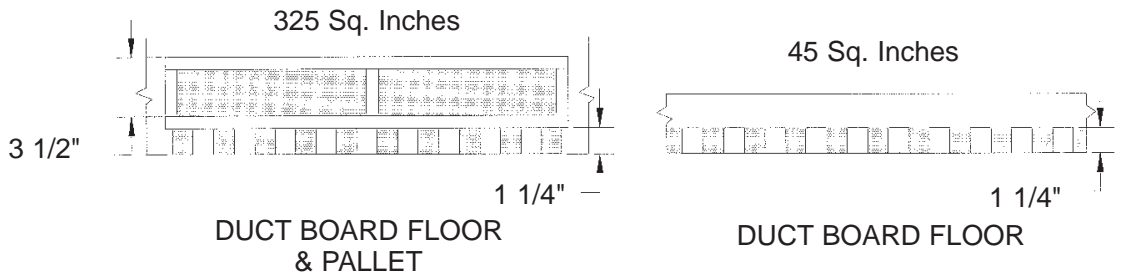

198 SQ. INCHES

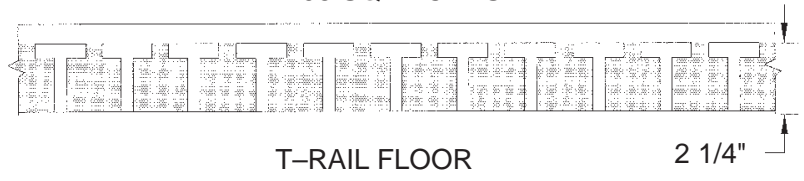

Figure 5.

Effect of different floor configurations on returnair space under the load.

for fast food and independent grocery stores. Multi-temperature vehicles usually have three compartments separately controlled at $0^{\circ} \mathrm{F}\left(-18^{\circ} \mathrm{C}\right)$ or below for frozen foods, around $35^{\circ} \mathrm{F}\left(2^{\circ} \mathrm{C}\right)$ for chilled foods, and around $55^{\circ} \mathrm{F}\left(13^{\circ} \mathrm{C}\right)$ for chill-sensitive products (figure 6).

Liquid $\mathrm{CO}_{2}$ refrigeration systems are used in some delivery operations. A major advantage of these systems is fast temperature recovery after door openings. This is particularly important for protecting the quality of frozen foods in warm weather where cumulative door opening time may be one or more hours. The injection of liquid $\mathrm{CO}_{2}$ into the compartments after a door opening provides almost instantaneous recovery to the thermostat set-point.

Mechanically refrigerated vehicles have a separate coil in each compartment. Each coil operates from a single refrigeration unit at an independent temperature set-point .

\section{Humidity}

The proper humidity or moisture content of the air surrounding fresh fruit and vegetables helps maintain quality during transport. Most perishable horticultural products require high relative humidities of 85 to 95 percent to prevent dehydration and to keep them fresh and crisp.

Relative humidity, as used in this text, is the percentage of water vapor in the air in relation to the saturation point of the air at a given temperature.

In mechanically refrigerated vehicles, moisture is continually evaporated from the product and condensed from the circulating air by the refrigeration coil. Some product moisture loss during transit must be accepted, but it can be minimized by the following practices:

- using top- or package-ice where possible;

- precooling thoroughly to reduce the temperature differential between the product and the surrounding air;

- keeping the refrigeration coil only a few degrees colder than the desired transit temperature; 


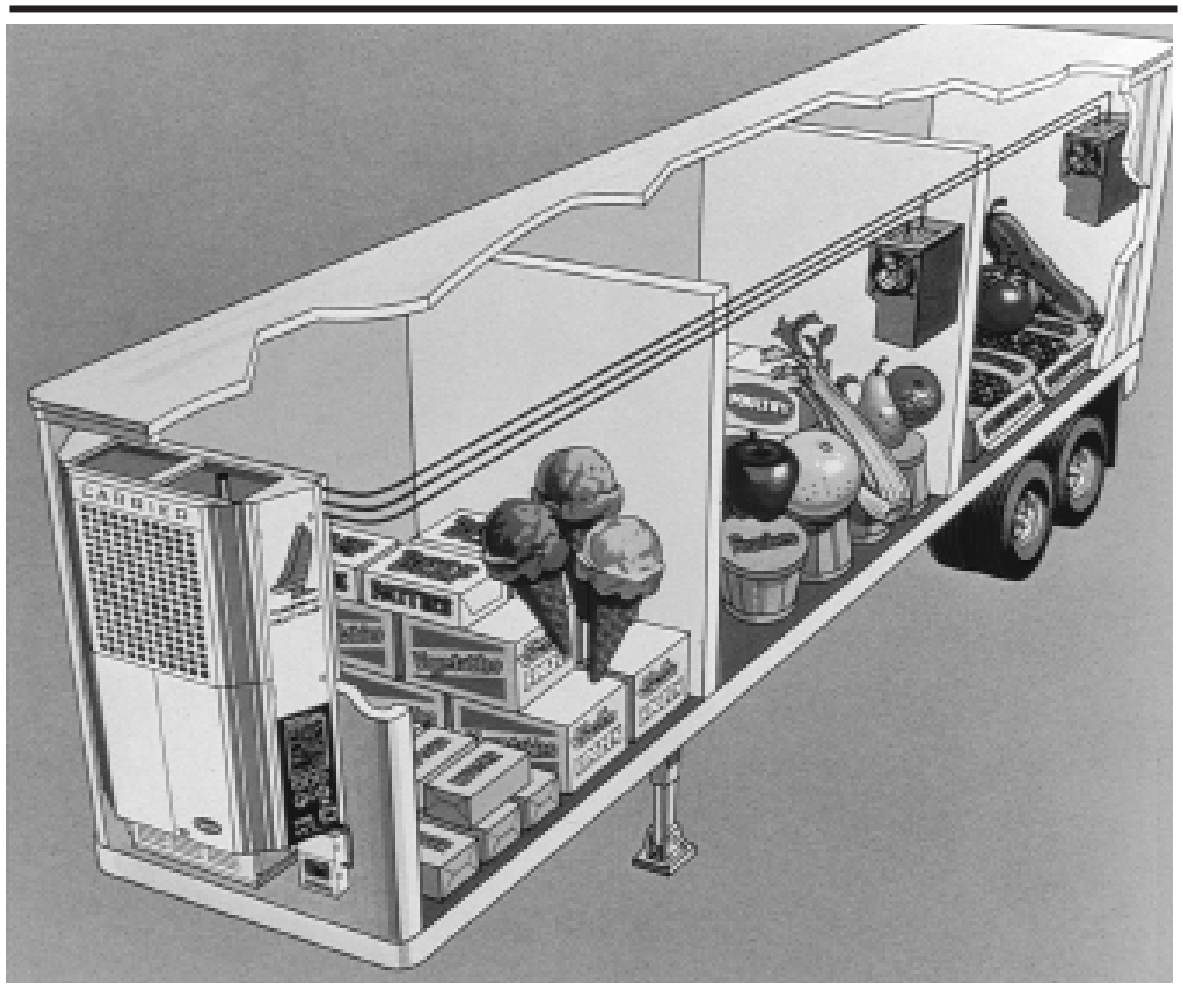

Figure 6.

Photo courtesy of Carrier-Transi-

A typical multi-temperature mechanically refrigerated trailer.

- waxing the product or using semi-permeable wraps to reduce evaporation; and

- installing a humidity control system.

\section{Precooling the Product}

To maintain a fresh appearance, prevent decay, and extend the market life of most fresh fruits and vegetables, it is necessary to start lowering the temperature and removing the field heat from the product as soon after harvest as possible. Any cooling completed before the product is shipped is referred to by the industry as precooling. Precooling may include one or a combination of the following methods:
- refrigerated forced air;

- vacuum cooling;

- hydrocooling; and

- slush- or package-ice.

Some fresh fruits, vegetables, and carcass meats are shipped before they have been precooled to the proper transit temperature. The ideal situation would be for the carrier to accept only properly precooled product. When this is not practical, the trailer's refrigeration system must bear the additional heat load.

Most truck refrigeration units have enough reserve capacity to remove a reasonable amount of heat in addition to respiration heat and heat transferring through the vehicle 
body. However, if the product is much above the desired transit temperature at loading time, the entire heat load should be estimated (see appendix I). If the estimated heat load is more than the refrigeration unit is rated to bear, the trailer should not be used.

\section{Freezing and Chilling Injury}

Trucks transporting perishables through areas with outside temperatures much lower than $32^{\circ} \mathrm{F}\left(0^{\circ} \mathrm{C}\right)$ may need to be warmed rather than refrigerated to prevent freezing or chilling injury. Product freezing also may occur if the thermostat setting is too low, particularly on the top layer where air exits the refrigeration unit discharge chute.

Freezing fresh meat will darken its color and increase thaw drip. Eggs may crack and incur irreversible physical changes by freezing. The texture of some cheeses are changed by freezing.
Freezing losses are most common in fruits and vegetables such as apples, celery, and lettuce which normally move at temperatures near their freezing point. The extent of injury varies with the characteristics of the product and the severity of freezing. Commodities such as beets and cabbage can withstand light freezing and thawing several times without permanent injury. Other products such as potatoes and tomatoes are permanently injured by only one slight freezing. Table 2 groups certain commodities by their sensitivity to freezing injury.

Some fresh fruits and vegetables are subject to low temperature or chilling injury at temperatures above $32^{\circ} \mathrm{F}\left(0^{\circ} \mathrm{C}\right)$. Symptoms may be pitting, discoloration, off-flavors, physiological deterioration, and increased decay. Chilling injury varies with both time and temperature. Some commodities, such as bananas, will be injured by a few hours'

\section{Table 2. Sensitivity of Some Fruits and Vegetables to Freezing}

\begin{tabular}{lll}
\hline Most sensitive $^{\mathbf{1}}$ & Moderately sensitive & Least sensitive $^{\mathbf{2}}$ \\
\hline Apricots & Apples & Beets \\
Asparagus & Broccoli, sprouting & Brussels sprouts \\
Avocados & Cabbage, new & Cabbage, old \\
Bananas & Carrots & Dates \\
Beans, snap & Cauliflower & Kale \\
Berries & Celery & Kohlrabi \\
Cucumbers & Cranberries & Parsnips \\
Eggplants & Grapefruit & Rutabagas \\
Lemons & Grapes & Salsify \\
Lettuce & Onions, dry & Turnips \\
Limes & Oranges & \\
Okra & Parsley & \\
Peaches & Pears & \\
Peppers, sweet & Peas & \\
Plums & Radishes & \\
Potatoes & Spinach & \\
Squash, summer & Squash, winter & \\
Sweet potatoes & & \\
Tomatoes & & \\
\hline
\end{tabular}

\footnotetext{
${ }^{1}$ Commodities likely to suffer injury by one light freezing.

${ }^{2}$ Commodities able to recover from one or two light freezings.

${ }^{3}$ Commodities that can be lightly frozen several times without sustaining serious damage.

${ }^{4}$ Except cranberries.
} 


\section{Table 3. Some Fruits and Vegetables Subject to Chilling Injury at Above- freezing Temperatures}

\section{Commodity}

Approximate lowest safe temperature ${ }^{1}$
Avocados:

Cold-tolerant varieties

${ }^{\mathrm{o}} \mathrm{F}$

${ }^{\circ} \mathrm{C}$

Cold-intolerant varieties

(West Indies)

Bananas

Beans (snap)

Cucumbers

Eggplants

Grapefruit

Lemons

Limes

Mangoes:

Irwin and Zill varieties

Haden and Keitt varieties

Melons:

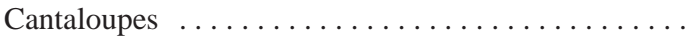

Honeydew, Casaba, Crenshaw,

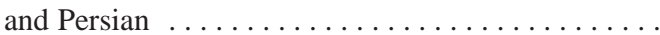

Watermelons

Okra

Oranges (California and Arizona

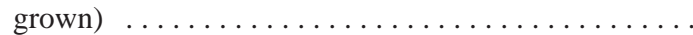

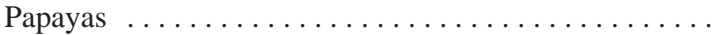

Peppers (sweet)

Pineapples:

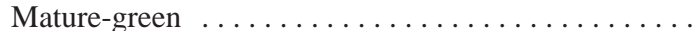

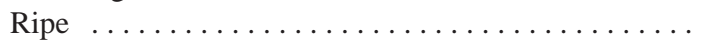

Potatoes:

Table stock .........................

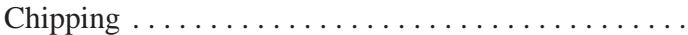

Pumpkins and hardshell squashes $\ldots \ldots \ldots \ldots \ldots \ldots$

Sweet potatoes

Tomatoes:

Mature-green

Pink
40

4.4

55

\footnotetext{
${ }^{1}$ Based on maximum transit time of 5 days; however, chilling injury may vary considerably by cultivar, harvest season, holding time, maturity of commodity, etc.
}

exposure to chilling temperatures. Others can be held below the desired storage temperature for several days before incurring serious injury. Table 3 lists some of the major fresh produce susceptible to chilling injury when held below recommended temperatures during transit or storage. 
Since heat moves toward the cold source, during very cold weather the heat from product loaded against the walls and floor in a truck will move outward. The best methods of preventing this heat loss and subsequent freezing or chilling damage are:

- reducing the amount of surface contact of the product with the floor and walls; and

- circulating warmed interior air around the perimeter of the load.

Various loading methods may be used to reduce product contact with the walls and floor. For example, the offset-by-layers loading pattern reduces box contact with the walls by about 50 percent and also provides ducts for warm air to circulate along the length of the wall (figure 7a). Hand-stacked loads of bagged products can be pyramid stacked (figure $7 \mathrm{~b}$ ). Palletized loads should be centerloaded away from the walls (figure 7c).

Enhance perimeter air circulation by using high airflow or deep T-rail floors (figure 5). If the vehicle is not equipped with deepchanneled floors, use pallets or disposable wooden floor racks to prevent contact of the product and floor and for more space for the warmed air to circulate under the load.

Ribbed or vertically grooved walls will allow increased air circulation down the walls and reduce surface contact with the product.

\section{Controlled and Modified Atmospheres}

The practice of using controlled or modified atmospheres as a supplement to refrigeration is increasing. Such atmospheres are achieved by altering the normal atmosphere in the vehicle with varying concentrations of one or more gases, usually oxygen $\left(\mathrm{O}_{2}\right)$, carbon dioxide $\left(\mathrm{CO}_{2}\right)$, and nitrogen $\left(\mathrm{N}_{2}\right)$.

A controlled atmosphere (CA) is attained when concentrations of gases making up the atmosphere in a vehicle are constantly replenished to maintain predetermined levels. In modified atmospheres (MA), gas concentrations are initially modified to meet specific product criteria, but not consistently replenished in transit to maintain the initial levels.
Nearly every product, and sometimes each variety, has a different combination of gases in which it keeps best during storage. An atmosphere that improves the keeping qualities of one product may have an adverse effect on another. Temperature and humidity modify the effects of controlled atmospheres. For these reasons, consult appendix II of this handbook and information on individual commodities in the USDA Handbook No. 66 (see Selected Bibliography) before applying a modified atmosphere to a product load.

Strawberries are the product most commonly shipped in a modified atmosphere. $\mathrm{CO}_{2}$ gas is a basic component in atmospheres for berry and cherry shipments because it is a mold retardant. $\mathrm{N}_{2}$ gas usually is a basic component for green leafy produce since $\mathrm{CO}_{2}$ gas may cause discoloration of these products. Reducing $\mathrm{O}_{2}$ levels retards ripening and decay that take place in normal air. Extremely high or disproportionate levels of any gas may result in product discoloration and off-flavors.

Sealing the trailer tightly enough to hold the desired concentrations of gases during transit is a major problem in truck shipments. A more common practice is to load the trailer, apply a plastic film curtain sealed around the inside of the rear doorway, evacuate the air through port valves, and then inject the desired atmosphere. In some cases, a large plastic bag enclosing the entire cargo space is inserted in the trailer, the product is loaded inside the bag, the bag is sealed and the desired atmosphere is injected. For transit periods of more than several days, vehicles containing a modified atmosphere should be recharged with gas enroute.

For both truckload and less than truckload lots, individual pallet loads of the product are sealed in plastic bags, the air evacuated, and a modified atmosphere injected. The preparation of vehicles or pallet loads for MA shipments is usually done by companies specializing in this trade. They also market the applicable gases, usually under a registered trademark. In some cases they provide services for monitoring and recharging the atmospheres in transit. 
(A) CROSSWISE - OFFSET STACK

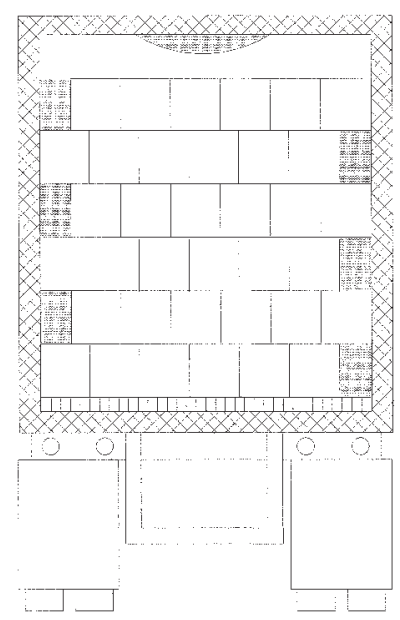

(B) PYRAMID STACK

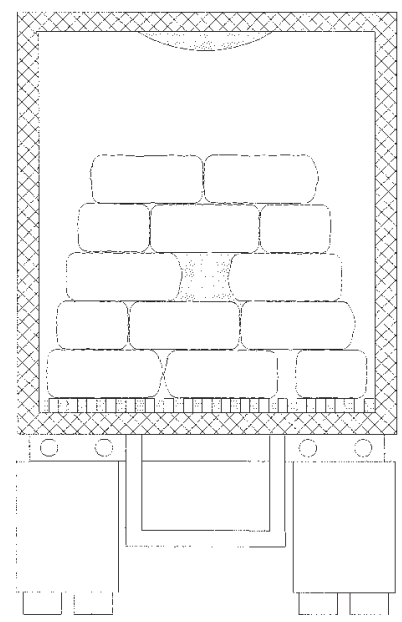

(C) CENTER - LOADED

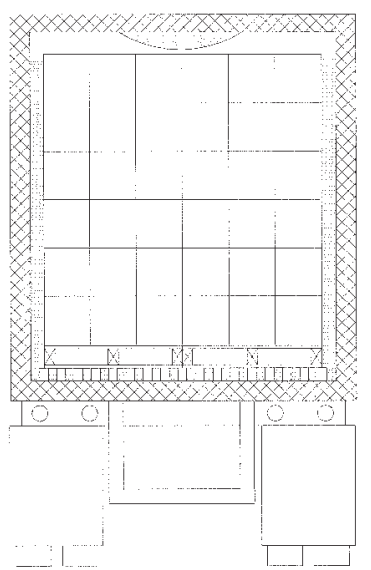

Figure 7.

Methods of loading to reduce contact of products with walls and to reduce the chance of freezing or chilling injury in extremely cold weather: (a) crosswiseoffset stacking of boxes or crates, (b) pyramid stacking of bagged products, and (c) centerloading of palletized loads. 


\section{Preparation for Loading}

Preparation for loading is an important step in putting together a successful shipment. When developing and implementing a good preloading plan, consider the following factors:

\section{Adequacy of Equipment}

The truck's refrigeration system should be operating properly and have the capacity to maintain the proper temperature of the intended product load. If the vehicle is NPLA/RTF certified, the refrigeration unit and insulation rating can be found on performance plates or decals attached at various locations (see figure 8). These decals also provide information on optional equipment on the trailer which affects refrigeration performance, such as bulkheads, air chutes, etc.

\section{Cleaning and Sanitation}

Clean and sanitize the vehicle. Cleanliness prevents bacterial, chemical, and odor contamination of food product loads. Remove all loose debris and wash or sweep the floors clean. The floor drains and grooves should be free of debris so drainage will not be blocked.

Certain cleaning procedures may be required by law in cases where a meat product may become contaminated by direct or indirect contact with the interior surfaces of the vehicle. Also, certain cleaning laws may apply due to previously hauled cargo, such as chemical residues or municipal wastes. (See also section VI, "Regulatory Considerations for Truck Construction Materials, Cleaning Compounds, and Sanitation.")

Fatty or oily food products, such as butter, oleomargarine, and meats, are highly susceptible to contamination by strong odors. Fresh fruit, such as apples and bananas, also easily absorb strong odors. Thorough cleaning and airing of vehicles previously used for hauling fish, cabbage, and other odorous products are necessary. Leaving freshly opened cans of ground coffee for 8 or more hours in a closed vehicle may be helpful in absorbing odors. The grounds may be spread over the floor and then swept clean before loading. Truckers should refrain from transporting products leaving strong residual odors if they plan to haul fresh meats or other odor-absorbing products soon after.

\section{Vehicle Maintenance}

Properly maintain vehicles. A regular maintenance program that keeps a refrigerated truck in good repair improves its ability to maintain desired product temperatures during transit. In the long run, maintenance and repairs are less costly than claims and lost revenue from delivery of products in poor condition.

Rough or splintered sidewalls and protruding nails or screws can tear containers and damage the commodity. Cracked wall liners provide lodging points for dirt and old food particles which encourage microbial and insect infestation. Walls punctured by forklifts or broken at the seams allow moisture to penetrate the insulation and reduce its effectiveness.

Check door seals and floor drain caps regularly and repair or replace as needed. The mashed-end rubber caps on floor drains tend to clog with debris, and wash crews sometimes cut them off. All seals should be maintained. Dirt and air are sucked into open spaces left by worn and missing seals and drain caps. This adds to refrigeration loads and product contamination.

Keep air chutes or ducts in place and free of holes. The ducts are designed to distribute air so that the load is uniformly cooled. Defective or missing ducts will result in air 


\section{REFRIGERATION CAPACITY}

(TEMPERATURE CONTROL UNIT MANUFACTURER'S NAME)

TEMPERATURE CONTROL UNIT PERFORMANCE

Cooling

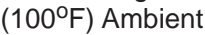

35ㅇ Btu/hr

$0^{\circ} \mathrm{F}-\mathrm{Btu} / \mathrm{hr}$

$-20^{\circ} \mathrm{F}-\mathrm{Btu} / \mathrm{hr}$
Heating

( $0^{\circ} \mathrm{F}$ Ambient)

$65^{\circ} \mathrm{F} \quad \mathrm{Btu} / \mathrm{hr}$

$35^{\circ} \mathrm{F} \_\mathrm{Btu} / \mathrm{hr}$
Air Discharge

No Load

System Load CFM CFM

MODEL

Tested in accordance with the Refrigerated Transportation

Foundation.

Recommended Practice No.

(latest revision)

\section{HEAT TRANSFER CHARACTERISTICS}

(VEHICLE MANUFACTURER'S NAME)

THERMAL PERFORMANCE

This structure is certified in accordance with Truck Trailer Manufactuers Association Recommended Practice No. 38 (latest revision) and Refrigerated Transportation Foundation Method for Classification, Recommended Practice

No. (latest revision)

V.I.N.

Date of Certification

Heat Transmission Rate

Floor Airflow Area

Side Lining Airflow Area $\mathrm{BTU} / \mathrm{hr}-{ }^{\mathrm{O}} \mathrm{F}$ $i^{2}$ $\mathrm{in}^{2} / \mathrm{ft}$ of vehicle length

Rear Door Airflow Area in $^{2}$

Figure 8.

Location of NPLA/RTF certification plates and decals which provide information on refrigeration rating and optional equipment on refrigerated trailers at time of manufacture.

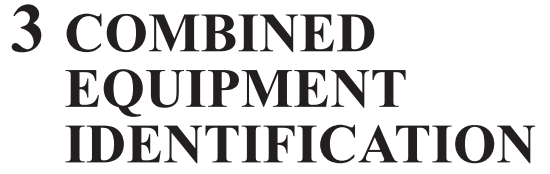




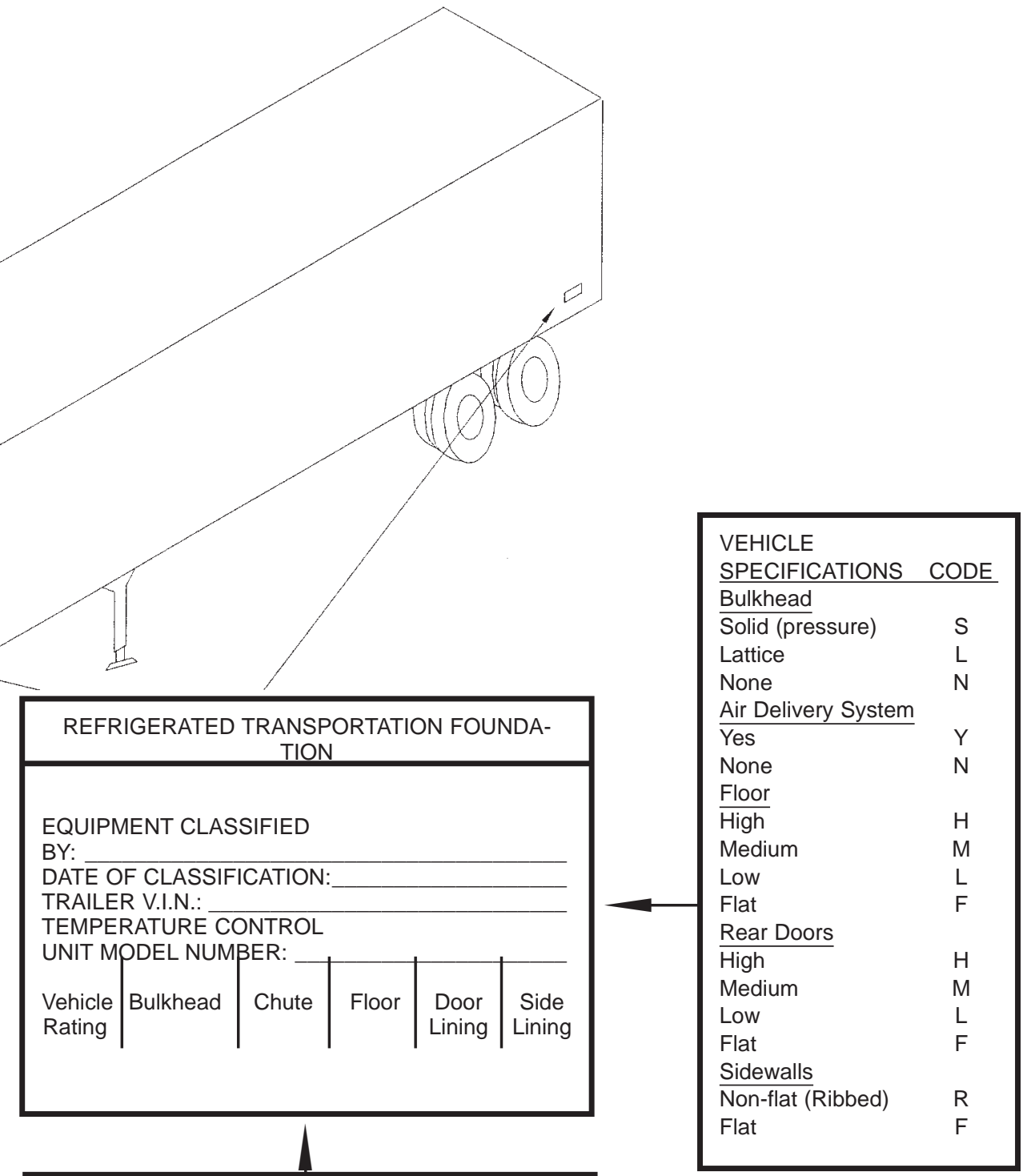

\begin{tabular}{|ll|}
\hline \multicolumn{2}{|c|}{ QUALITY PRODUCT PROTECTION } \\
Vehicle Ratings & $\begin{array}{l}\text { Type of Product Protection } \\
\text { Controlled Temperature }\end{array}$ \\
\hline $\mathrm{C} 65=65 \mathrm{~F}$ & Fresh Fruit and Vegetables \\
\hline $\mathrm{C} 35=35 \mathrm{~F}$ & Frozen Foods \\
\hline $\mathrm{F}=0 \mathrm{~F}$ & Ice Cream \& Frozen Foods \\
\hline $\mathrm{DF}=-20 \mathrm{~F}$ & \\
\hline
\end{tabular}


short-circuiting back to the refrigeration unit over the top of the load. This often causes freezing on the top layer and hot spots in the lower layers.

\section{Precooling or Prewarming of the Vehicle}

Precool or prewarm the vehicle to the desired transit temperature for the intended product load. During hot weather, precooling reduces the chance of overloading the refrigeration system. It also prevents further warming or thawing of the product from heat in the walls and floor. A number of variables, such as ambient temperatures, refrigeration unit capacities, and insulation, make it hard to have a set procedure for precooling. A recommended procedure is to set the thermostat at the desired temperature, close the doors of the vehicle, and run the refrigeration unit until the heat transfer through the vehicle body is stabilized at the thermostat set-point. This may take 2 or more hours in hot summer weather. Some of the newer refrigeration units are equipped with micro-processors with an automatic precooling cycle function. Still, schedule adequate time for precooling.

CAUTION: Shut the refrigeration unit off when loading from an open dock. Leaving the doors open may result in ice forming on the refrigeration coil, blocking refrigerated air circulation during transport.

During extreme subfreezing weather, prewarm the interior of the vehicle before load- ing commodities such as fresh onions or potatoes. Most vehicles are equipped with a heating cycle on the refrigeration unit. Operate the unit on the heat cycle far enough in advance of loading to stabilize the interior air and body temperature of the trailer at the desired transit temperature of the product.

\section{Preloading Checklist}

The following is a suggested preloading checklist:

( ) Refrigeration unit operating properly?

( ) Thermostat calibrated?

( ) Refrigeration air chutes or ducts properly installed and in good repair?

( ) Door seals in good condition?

( ) Doors seal tightly when closed?

( ) Walls free of cracks or holes?

( ) Front bulkhead installed?

( ) Floor drains open?

( ) Inside of the vehicle clean and odor free?

( ) Floor grooves free of debris?

( ) Inside length, height, and width adequate for the load?

( ) Load locks or other devices available to secure load?

( ) Is the trailer or container precooled or prewarmed? 


\section{Loading Considerations}

The packaging, handling, and trailer equipment for perishable foods varies considerably, and this complicates loading decisions for truck drivers. Consider the following factors, along with the kind of equipment available, when planning a load.

\section{Type of Air Delivery}

Currently there two types of air delivery systems available on refrigerated trailers and containers. Each system requires different loading procedures for both hand-stacked and palletized loads to maximize cooling efficiency and maintain temperature control.

Top-air delivery is the conventional system used in refrigerated trailers (see figure 2). With this system, high velocity, but low pressure, air exits the refrigeration unit at the front ceiling, travels over the top of the load, down between the end of the load and rear doors, and under and through the load to return to the refrigeration unit at the front of the vehicle. When loading a top-air vehicle, keep pathways open for airflow back to the refrigeration unit. For respiring produce, air pathways also are needed through the load interior for removal of respiration heat.

Bottom-air delivery systems are used mainly on intermodal van containers for export shipments. In bottom-air systems, refrigerated air is forced down the front bulkhead and under the load through a T-rail floor, and then vertically up through the load (see figure 3). A high static pressure is maintained under the load to assure a low velocity but steady movement of air through small openings in the load. Load a bottom-air vehicle tightly over the floor area, and cover any open space on the floor not covered by the load to maintain the air pressure under the load.

\section{Type of Shipping Container}

Load shipping containers in a manner that takes maximum advantage of their inherent strength. Different containers are stacked and handled in varying ways because of their design, the way they are packed, and the material from which they are made. Most containers are designed to withstand more pressure or weight on one side or area without collapse or damage to the contents. Certain types of "packs" tend to leave a bulge on one or more faces of the container. If at all possible, do not load bulged containers with pressure on the bulging faces. Wooden wirebound crates used for corn are an example of this type pack. Load these containers on their sides to prevent crushing of the contents under the bulge.

Wooden boxes, lugs, and wirebound crates are designed to bear weight on the ends only. The tops, bottoms, and sides usually are made up of thin slats which serve only to keep the product within the container. Stack these containers directly on each other so that the overhead weight is borne by the ends of the crate, or the contents may be severely crushed and bruised.

Corrugated fiberboard boxes are designed to bear vertical overhead weight on their four walls. Load fiberboard boxes upright on their bottoms and stack evenly on top of each other. The four corners are the strongest points. Avoid cross-stacking where excessive pressure put on the boxes at midsection may cause product damage. Boxes may usually be cross-stacked on the top layer.

Wooden baskets and hampers are designed to withstand overhead weight bearing vertically on their tops or bottoms. Fasten the cover lids securely at all fastening points so that the lid bows slightly. The bow distrib- 
utes overhead weight evenly to the sides of the basket rather than letting it bear directly on the produce under the cover.

Bulk and bagged commodities are highly susceptible to bruising from overhead weight, especially when loaded on grooved or rough floors. Commercial cushioning materials, such as paper and plastic foam pads, will provide some protection for these products. Fiberboard slipsheets also may be used for floor cushioning. Any cushioning material should be perforated for air circulation. Do not use materials, such as straw, that will block air circulation under the load.

During cold weather, floor cushioning material also serves as insulation to prevent freezing damage at the point it is most likely to occur. However, the most effective method of preventing freezing of the product at floor level is to circulate warmed air under the load. In vehicles not equipped with high airflow floors, raise the load on pallets or floor racks to get adequate air circulation under the load.

\section{Whether Frozen or Nonfrozen}

Load frozen foods that have been cooled to the desired $0^{\circ} \mathrm{F}\left(-18^{\circ} \mathrm{C}\right)$ or below transit temperature in a different manner from fresh respiring produce. Load boxes of frozen food tightly together with as little contact with the vehicle floor and walls as possible. The goal is to have cold air circulating around the load perimeter to intercept heat radiating through the body of the trailer before it reaches the frozen cargo. (See also the section "Frozen Foods.")

\section{Bracing Needs}

Bracing prevents the load from shifting and blocking air circulation channels and/or causing physical damage to the product. It is especially important to secure containers in the top layers toward the rear of the load. Here they are highly susceptible to bouncing and toppling, and subsequent bruise and abrasion damage from shock and vibration transmitted from the road bed.
Prevent the accumulation of lengthwise slack space during loading. Use cross-bracing at the end of the last stack to prevent the cargo from shifting backward and blocking air circulation at the rear doors. This is particularly important in loads for piggyback rail (TOFC) shipments, where the vehicles may be loaded so they are moving backwards. If the load is a split shipment or a multiple drop-off (one that is consigned to several receivers), use cross-bracing at the end of the last stack left after each drop-off to keep the cargo in place until the next stop is reached. Use air bags, spacer blocks, and load lock bars to secure palletized loads.

\section{Compatibility of Mixed Loads}

Many truck shipments contain two or more different food products. Consider five important factors in determining the compatibility of products in mixed loads:

(1) required commodity temperature,

(2) required relative humidity,

(3) emission of physiologically active gases such as ethylene,

(4) odor-absorbing characteristics, and

(5) modified atmosphere requirements.

The desired transit temperature of products shipped together should be within reasonably close range. For example, mature green tomatoes requiring a transit temperature of $55^{\circ} \mathrm{F}\left(13^{\circ} \mathrm{C}\right)$ should not be shipped in combination with lettuce needing a transit temperature of $32^{\circ} \mathrm{F}\left(0^{\circ} \mathrm{C}\right)$.

The relative humidity requirements of mixed products should be reasonably close. Some products may be shipped in contact with ice and saturated by melt water. Other products may be injured by contact with ice or water saturation.

Certain fruits and vegetables produce ethylene gas during respiration. Ethylene may bring about premature ripening or it may damage carrots, lettuce, most flowers, and some nursery stock. Fruits and vegetables 
producing significant quantities of ethylene are apples, avocados, bananas, cantaloupes, honeydew melons, peaches, pears, plums, and tomatoes. Commodities that should retain a green color during transit, such as bananas, cucumbers, and peppers, should not be shipped in combination with heavy ethylene producers. Ethylene production is less pronounced at temperatures near freezing than at higher temperatures. Exchanging the air in the vehicle periodically by opening vent doors will help reduce ethylene buildup. Ethylene scrubbers also are available commercially.

Take care not to mix shipments of odor-producing products with odor absorbers. Odors given off by apples, citrus, onions, pineapples, and fish are readily absorbed by dairy products, eggs, meats, and nuts. Some products, such as apples, are capable of both giving off and receiving odors. Loading combinations to avoid are apples or pears with celery, cabbage, carrots, potatoes, or onions; celery with onions or carrots; and citrus fruits with any of the strongly scented vegetables. Apples and pears may acquire an earthy taste and odor if shipped with potatoes.
Use the "Load Compatibility Groups" section in appendix II for determining the loading compatibility of various products.

\section{Whether Palletized or Unitized}

Depending on the commodity and area of production, anywhere from 75 to 90 percent of the fresh fruit and vegetable shipments are now unitized on pallets or slipsheets. Unitized shipments offer the advantages of reduced labor and less manual handling of the product, but have unique loading requirements for protecting food products during transit. (See also the section "Loading Methods.")

\section{Length of Transit Period}

The length of time a product will be in transit will affect loading decisions. For example, a denser loading pattern can be used in an overnight shipment compared to one that takes several days in summer heat. In overseas shipments where transit periods may be 2 weeks or longer, it is imperative that all of the recommended transit requirements for the individual commodity be met to assure maximum shelf life. 


\section{Loading and Load Patterns}

\section{Basic Terminology}

Figure 9 is a dimensional view of a load in a truck trailer showing arrangement of containers in rows, stacks, and layers. A row is a line of containers extending the length of the trailer, one container in width, and as high as the load itself. A layer is a course or stratum of containers, one container high, usually extending the length and width of the trailer. A stack is a line of containers extending from one side wall to the other and from the top to the bottom of the load, parallel to the front and rear end of the vehicle, and one container in length.

\section{Loading Vehicles with Top-air Delivery}

\section{Hand-stacked Loads}

When hand-stacking respiring product in trailers with top-air delivery, use an airflow pattern. The goal in airflow patterns is to build air channels through and around the load to maximize the circulation of refrigerated air for interception of heat penetrating the trailer body and removal of heat from the product. Figures 10a, b, and c illustrate a typical airflow pattern with horizontal air channels constructed between rows in alternate layers. This pattern may be modified in a number of ways to accommodate varying

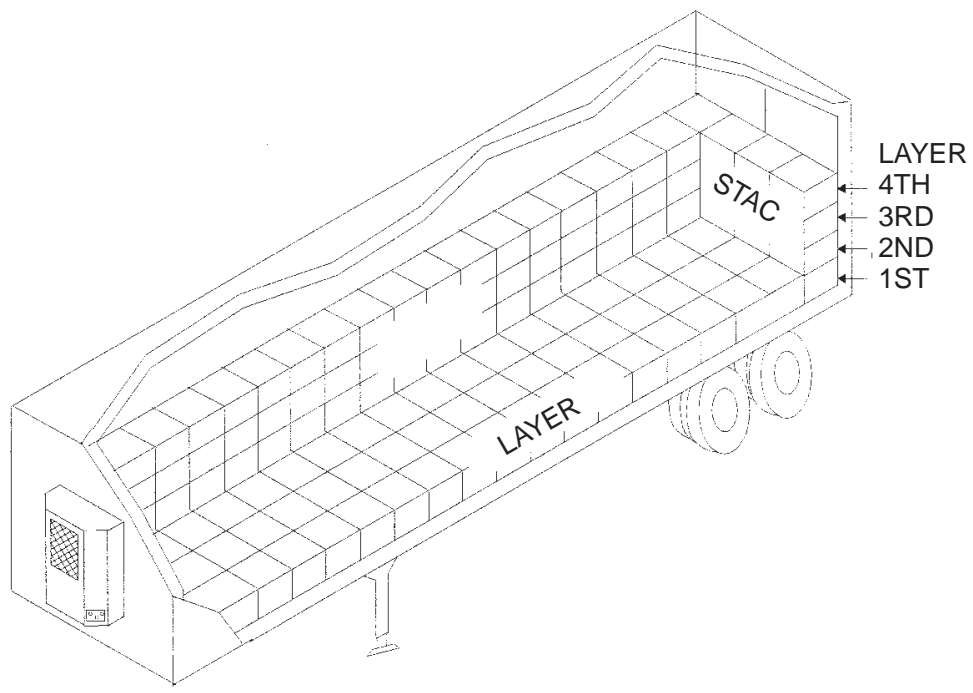

Figure 9.

Dimensional view of a

load in a truck semitrailer showing arrangerows, stacks, and layers. 
vehicle and container sizes (figure 11).

To maximize cooling of hand-stacked loads in vehicles with top-air delivery:

- use an airflow loading pattern for respiring products (figure 10);

- build a header or starter stack against the front bulkhead with vertical channels to facilitate air flow from the horizontal load channels back to the refrigeration unit (figures 10a and b); (After the starter stack, all other stacks in the load must be exactly the same, or the horizontal channels will be blocked.)

- load top boxes in a solid layer to prevent

(A) LONGITUDINAL VIEW

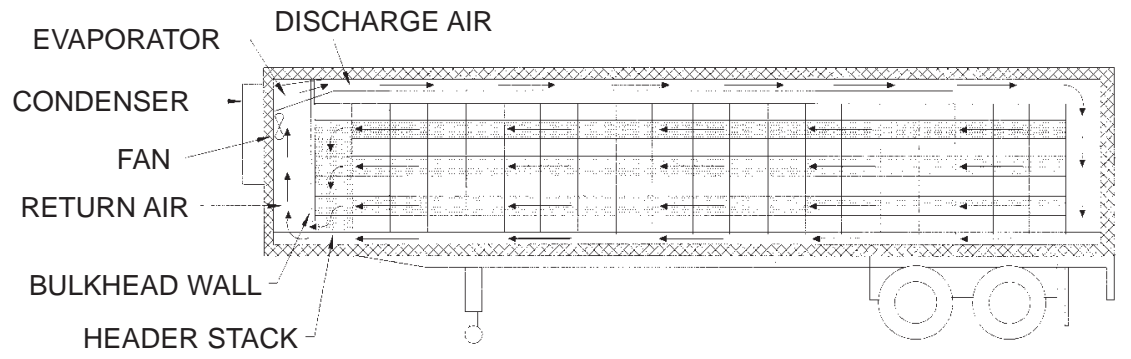

(B) HEADER STACK

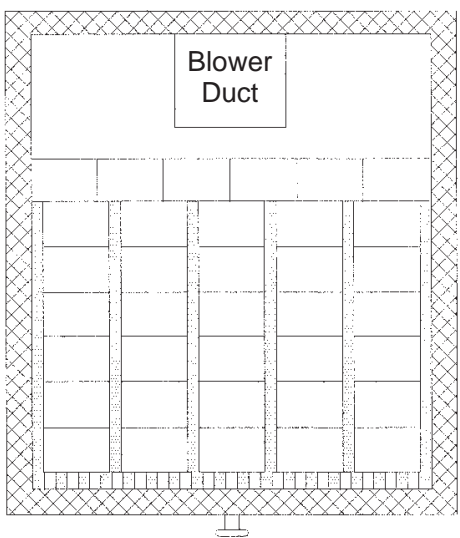

(C) REAR VIEW

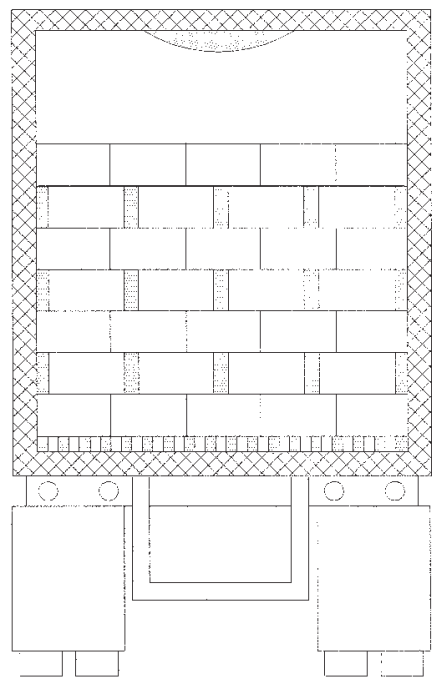

Figure 10.

A typical airflow loading pattern for commodities packed in fiberboard boxes: (a) longitudinal view, (b) header stack, and (c) rear view of all other stacks. 


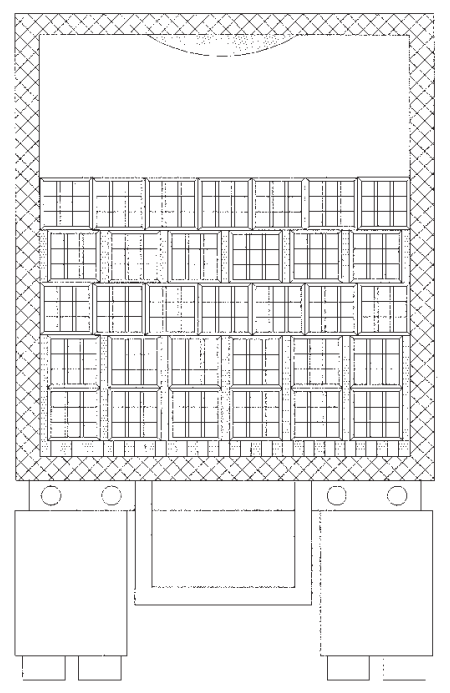

Figure 11.

Rear view of an airflow

loading pattern modified for wirebound crates.

air from short-circuiting back to the refrigeration unit;

- do not load so high that the air chutes are compressed and air circulation is blocked;

- allow at least 4 inches $(10 \mathrm{~cm})$ of open space between the end of the load and the rear doors for air return; and

- provide adequate space for air return under the load (figure 5). (If the floor channels are less than 2 inches $(5 \mathrm{~cm})$ deep, the product should be loaded on floor racks or pallets with their stringers running lengthwise for greater airflow under the load.)

\section{Unit Loads}

To enhance cooling of unit loads on pallets or slipsheets in trailers with top-air delivery:

- secure containers to each pallet with appropriate strapping, tape, plastic film, or netting;

- load the pallets in rows and off the walls (figures 12a and b);
- load the pallets with their stringers running the length of the trailer; and

- secure the load with spacers and bracing to prevent the product containers from toppling and blocking air spaces between the walls and rows of pallets.

\section{Loading Vehicles with Bottom-air Delivery}

Design load patterns in bottom-air delivery vehicles to maintain air pressure under the load. Respiring produce should be packed in boxes with top and bottom vent holes.

For hand-stacked loads in vehicles with bottom-air delivery the following apply:

- Load cartons tightly together from front to rear and sidewall to sidewall of the vehicle.

- Stack cartons with top and bottom vent holes directly on top of each other with the vent holes aligned.

- Leave at least 4 inches $(10 \mathrm{~cm})$ between the top of the load and the ceiling for air to return to the refrigeration unit.

- Block any space left open on the top of the T-rails at the rear of the vehicle so that air will be forced upward through the load and not short circuit around the end of the load at the doors (figure 3).

For unit loads on pallets or slipsheets in vehicles with bottom-air delivery, observe the following:

- Load the unit loads together as tightly as possible.

- Cover floor space not covered with the unit loads with fiberboard or other appropriate material to force the air up through the unit loads.

- Ensure that there are holes or slots in plywood pallet floors or slipsheets to allow refrigerated air into the unit load.

- For nonfrozen loads, block the ends of the pallets at the rear of the load to assure that air pressure is maintained under the load. 


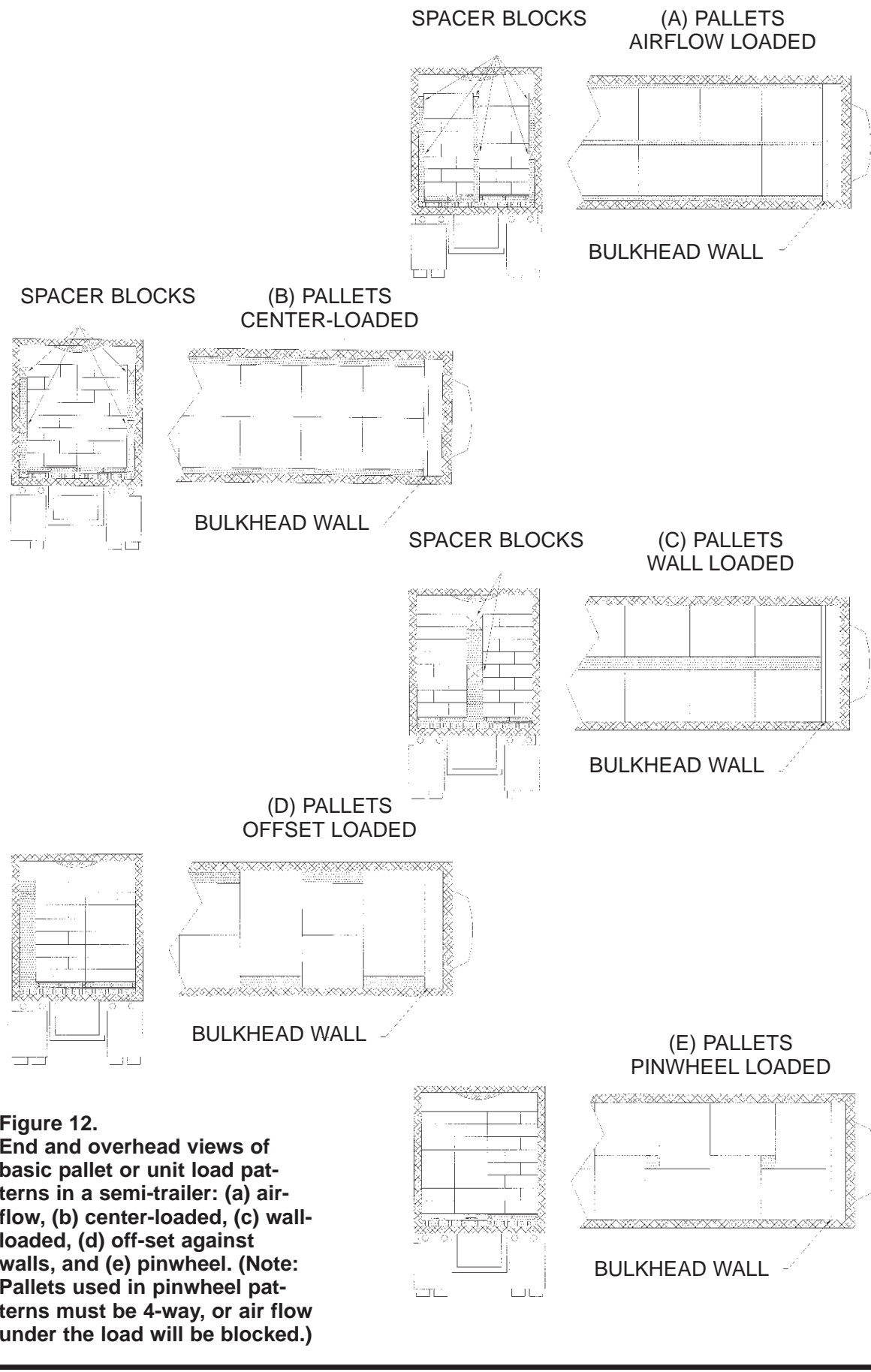


The load patterns in figures $12 \mathrm{c}$ and $\mathrm{d}$ are recommended for exporting palletized grapes and tree fruit in van containers with bottom-air delivery systems.

\section{Unit or Pallet Loads}

In top-air delivery trailers, unit or pallet loads are usually loaded in one of five basic patterns (figure 12). The dimensions of the pallet base and the interior dimensions of the vehicle will have considerable influence on the pattern used. The amount of bulge, overhang, whether top-iced, and ventilation requirements are other determining factors for unit load patterns.

Design unit load patterns to reduce the contact of the product with the walls and floor of the vehicle, especially if the vehicle is not equipped with inverted ribbed walls and deep channel or high airflow floors. Figure 13 shows the effect of unit and pallet load patterns on the amount of product exposed to contact with wall and floor surfaces. Reducing the amount of surface contact will improve product arrival temperatures and reduce the chance of product freezing or warming in extreme weather conditions.

Stack shipping containers for unit loads squarely on the pallets and stabilize to prevent toppling. Strapping, both vertical and horizontal, is a popular method for stabilizing unit loads. This method can be enhanced by the use of corner boards (figure 14). Also, palletizing glue (which has strength in shear and not in tension) may be used between layers of containers. Net wraps and plastic stretch or shrink film wraps also may be used.

CAUTION: Ensure that film wraps are not used on products that are improperly precooled and/or have a high respiration rate as the film may block ventilation and allow heat buildup. The top two or three layers of a unit load sometimes are cross-stacked and/or taped horizontally for stabilization.

Brace unit loads to prevent them from shifting against the rear doors and blocking airflow around the end of the load. Figure 15 illustrates an easily constructed wooden brace. Load lock bars also help prevent shifting.

Some loads are partly unitized and partly hand-stacked. In this case, put the handstacked portion on pallets to make it consistent with the rest of the load and allow better air circulation.

\section{Vented Loads}

In some cases, ambient air is vented through trailers to cool loads of fresh produce. Also, fresh air may be vented into the vehicle to prevent oxygen starvation or to displace metabolic gases such as ethylene or carbon dioxide. For proper ventilated cooling of hand-stacked loads, use an airflow loading pattern (figure 10). In a vented load, the air enters a vent door at the top front of the trailer, travels down under the bulkhead, through the horizontal air channels, and exits at a vent at the bottom of the rear door.

CAUTION: Ensure that the ambient air is near the product's desired transit temperature and not so cold or hot that it will injure the product. The product may also be damaged if substantial amounts of heat or fumes from the tractor's exhaust stack are able to enter through the front vent. When ventcooling loads, open all available vent doors at the rear of the trailer.

For vented cooling of unitized loads, the load patterns shown in figures $12 \mathrm{a}, \mathrm{b}$, and $\mathrm{c}$ are preferred.

\section{Top-iced Loads}

Use the pattern shown in figure 16 for handstacked loads that will be top-iced. Stack boxes or wirebound crates directly on top of each other in lengthwise rows. Divide the crosswise slack space evenly between the rows and walls for top-ice to fill. Place wood strips horizontally to stabilize the load and maintain space between the rows.

The recommended procedure is to apply the crushed ice on top of the load in three lengthwise windrows. The thermostat should 
PRODUCT ON SLIPSHEETS

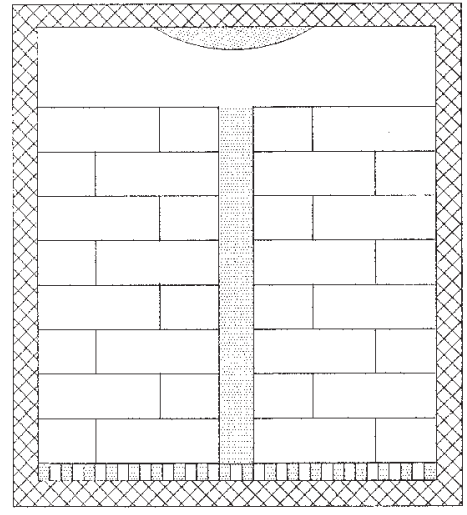

(a) WALL LOADED $=20 \%$

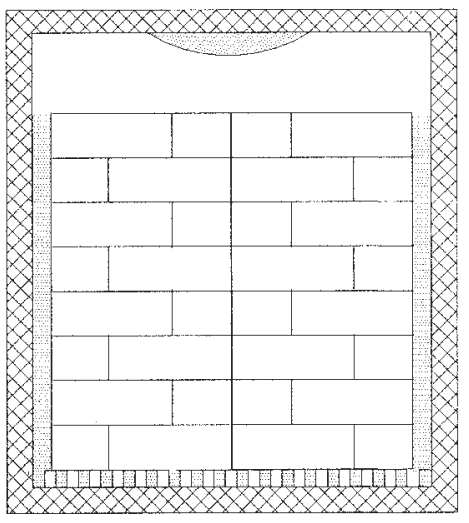

(b) CENTER-LOADED $=5 \%$

PRODUCT ON PALLETS

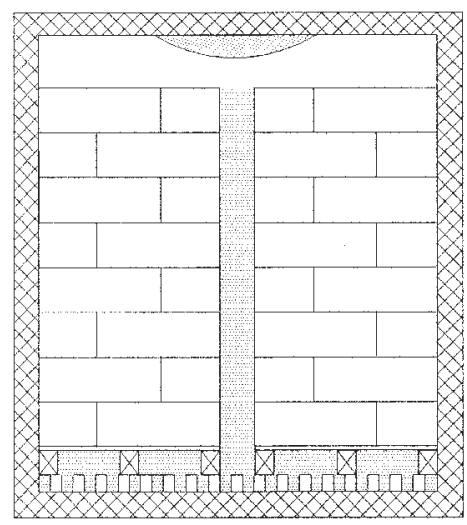

(c) WALL LOADED $=15 \%$

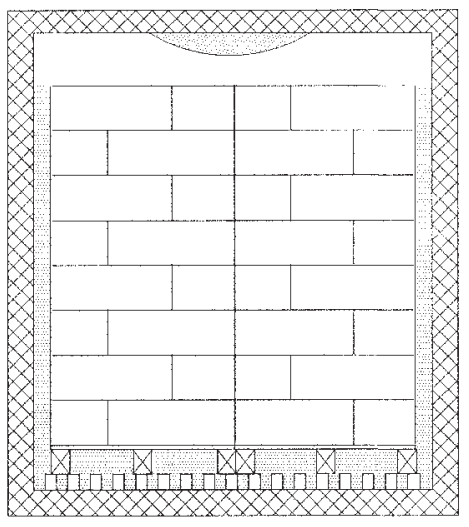

(d) CENTER-LOADED $=0 \%$

\section{Figure 13.}

\section{Effect of different unit} load patterns on the percentage of cartons contacting the floor and walls in a typical load of a perishable product.

be set at $35^{\circ} \mathrm{F}\left(2^{\circ} \mathrm{C}\right)$ to allow the ice to melt steadily during the trip. A colder setting may crust or freeze the ice and block air circulation, thus allowing heat buildup in the interior of the load.
CAUTION: Ensure that the crushed ice is not cold enough to freeze the produce on contact. Ice may come out of cold storage as cold as $25^{\circ} \mathrm{F}\left(-4^{\circ} \mathrm{C}\right)$. 
For palletized loads, the load patterns shown in figures $12 \mathrm{a}$ and $\mathrm{b}$ are preferred.

\section{Loading Checklist}

Use the following checklist when loading trailers with top-air delivery:

( ) Precool vehicle to desired thermostat setting.

( ) Shut off the refrigeration unit when loading at an open dock.

( ) Record product temperatures during loading.

( ) For hand-stacked loads, use an airflow loading pattern with a header stack and lengthwise air channels (figure 10).
( ) For both top- and bottom-air delivery vehicles, avoid loading tight against flat walls; use an offset-by-layers pattern for hand-stacked loads or center-load unit loads (figures 7, 10, and 12).

( ) Allow at least 4 inches $(10 \mathrm{~cm})$ of space between end of load and rear doors for return air.

( ) Use pallets on floor if floor channels or ducts are less than $21 / 4$ inches $(6 \mathrm{~cm})$ deep.

( ) Secure hand-stacked loads at rear with wood gates, load bars, or other devices.

( ) Secure unit loads with one or more of the following: air bags, bracing, shrink film or netting, or strapping.

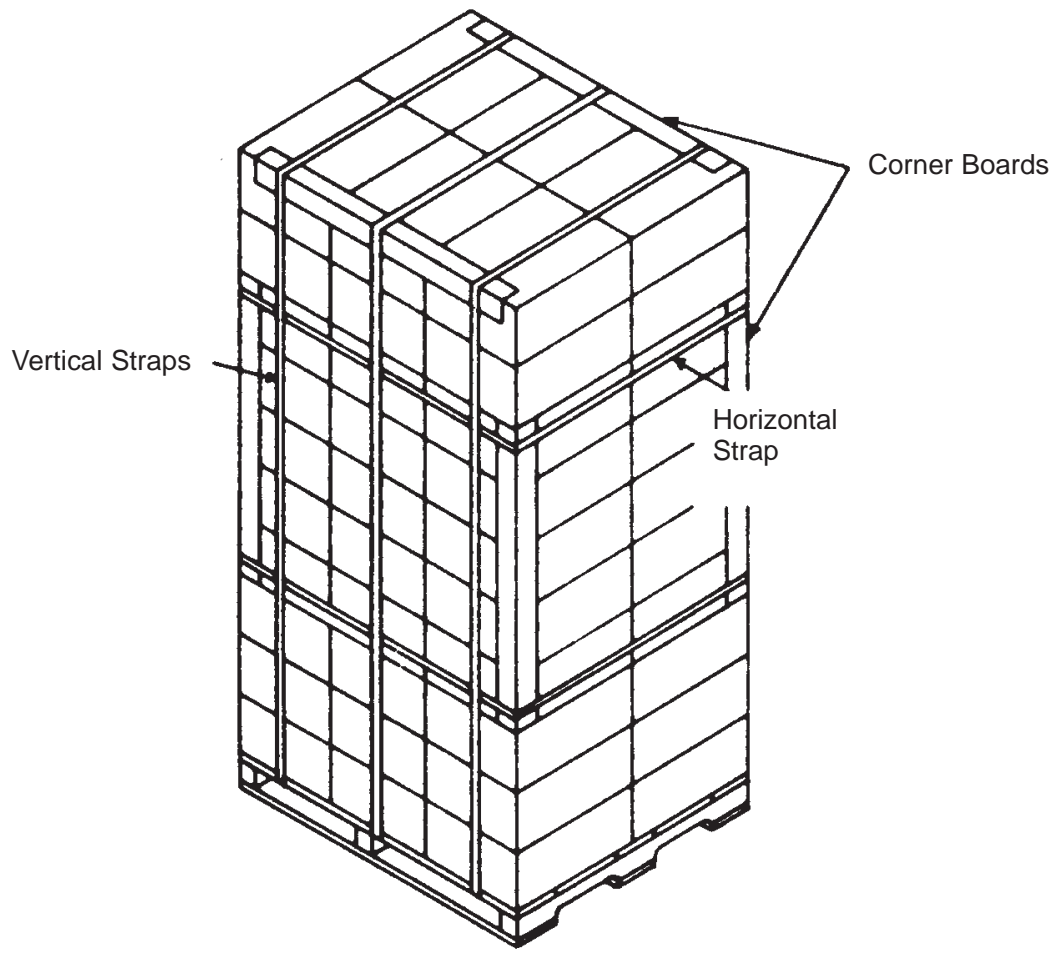

Figure 14.

Example of strapping and corner boards on a unit load. 


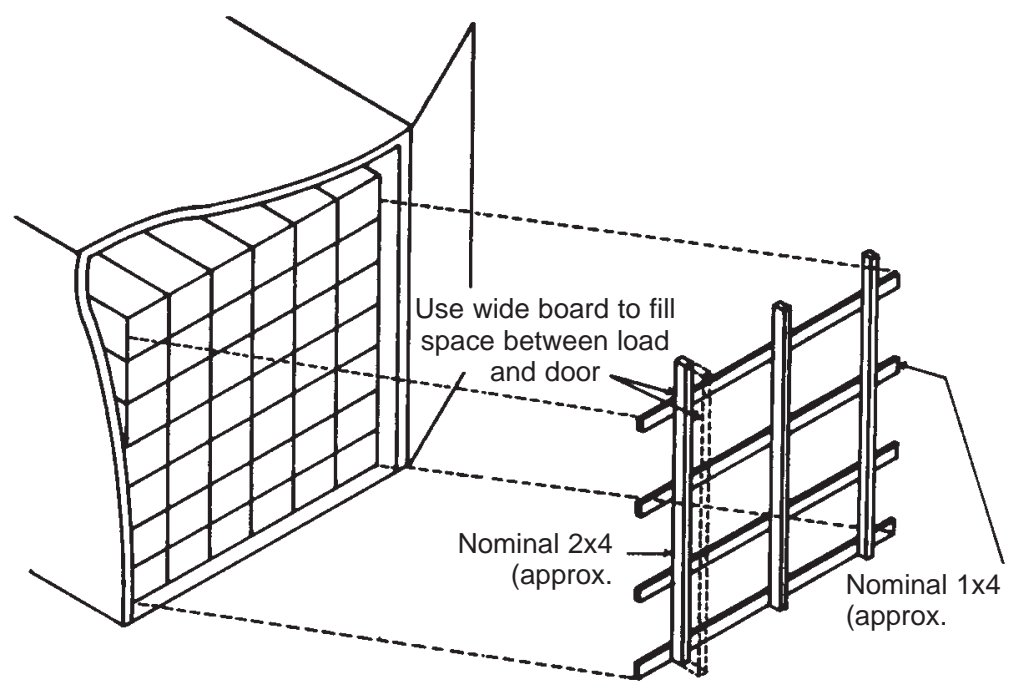

Figure 15.

Example of a method for bracing a load at the rear doors.

Figure 16.

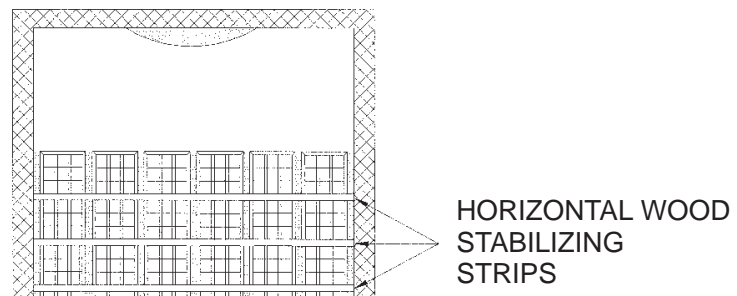

Rear view of a stacking

pattern with wood stabilizing strips for top-iced loads in wirebound crates (shown) or waxed fiberboard boxes. 


\section{Individual Commodity Requirements}

\section{Fresh Fruits and Vegetables}
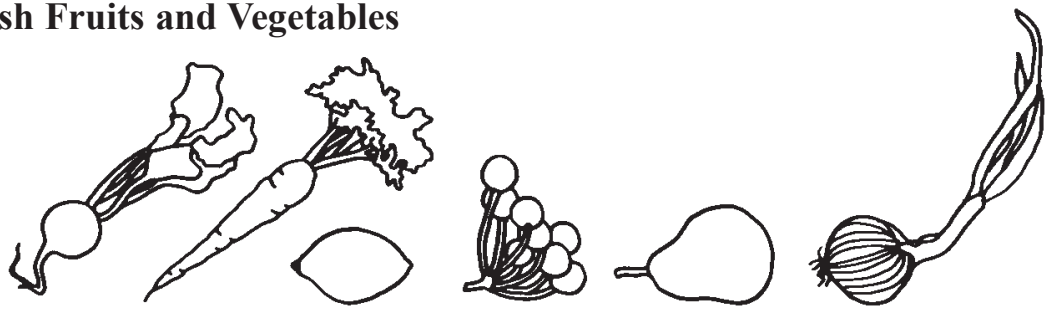

Quality and shelf life at destination will depend greatly on providing the recommended transport conditions. For loads with more than one commodity, consult "Load Compatibility Groups" in appendix II.

Make decisions on thermostat settings on a load-by-load basis, taking into account the operating characteristics of individual trailers, the loading temperature of the product, and the desired transit temperature for the product loaded.

CAUTION: Be careful when determining the thermostat setting for fresh or chilled products transported at temperatures near their freezing point. Considerable freezing or chilling damage could occur, especially on the top layer of the load. This is because air exiting the refrigeration unit may be several degrees below the thermostat setting to attain a cooling differential with the air at the return. For example, if the desired transport temperature of a product is $32^{\circ} \mathrm{F}\left(0^{\circ} \mathrm{C}\right)$ and the freezing point is $31.8^{\circ} \mathrm{F}\left(-0.1^{\circ} \mathrm{C}\right)$, then the thermostat setting would probably need to be in the $34^{\circ}$ to $36^{\circ} \mathrm{F}\left(1.1^{\circ}\right.$ to $\left.2.2^{\circ} \mathrm{C}\right)$ range to prevent product freezing.

\section{Apples}

\section{Recommended transport conditions:}

- Desired transit temperature:

Most varieties: $30^{\circ}$ to $32^{\circ} \mathrm{F}\left(-1^{\circ}\right.$ to $\left.0^{\circ} \mathrm{C}\right)$

Cortland, McIntosh, and Yellow Newtown: $38^{\circ}$ to $40^{\circ} \mathrm{F}\left(3^{\circ}\right.$ to $\left.4^{\circ} \mathrm{C}\right)$

- Desired relative humidity: 90 to 95 percent
- Highest freezing point: $30.0^{\circ} \mathrm{F}\left(-1.1^{\circ} \mathrm{C}\right)$

After harvest, most apples are held in bulk bins in cold storage until they are sold. As orders are received, apples are packed in corrugated fiberboard boxes. After packing, the apples are palletized for transport to the loading dock. At the loading dock, they may occasionally be removed from the pallets and hand-stacked in the trucks.

Apples ripen steadily at temperatures above $40^{\circ} \mathrm{F}\left(4^{\circ} \mathrm{C}\right)$ : Therefore, refrigerate them immediately after harvest. Hold and transport most varieties at the $30^{\circ}$ to $32^{\circ} \mathrm{F}\left(-1^{\circ}\right.$ to $\left.0^{\circ} \mathrm{C}\right)$ temperature range. Some varieties, such as McIntosh, are subject to chilling injury at long exposure to temperatures below $38^{\circ} \mathrm{F}\left(3^{\circ} \mathrm{C}\right)$.

Transport apples taken from cold storage at the same temperature at which they were stored. Since most apples are shipped at temperatures near their freezing point, they are quite susceptible to freezing injury. Thermostatically controlled heating should be used to prevent both freezing and overheating in extremely cold weather.

Mature apples coming from cold storage bruise more easily than those recently harvested and require more careful handling. Apples absorb odors quite readily. They should not be shipped in mixed loads of commodities like onions or cabbage, nor in trucks harboring strong odors. Apples also produce ethylene, and they should not be shipped with products sensitive to this gas. 
Recommended loading methods:

- Fiberboard boxes-Nearly all apples are shipped in fiberboard boxes. The apples may be packed in the boxes loose, in polyethylene bags, or in molded trays. Stack the boxes lengthwise or crosswise in the vehicle.

- Fruit from cold storage-Stack the boxes tightly together. However, in extreme hot or cold weather, use an offset by layers pattern for reduced contact with the walls and floor (figure 7).

- Palletized fruit-Center-load (figure 12b) in extreme hot or cold weather to reduce contact with walls. Do not overfill bin loads to prevent apples in the bottom bins from being bruised.

\section{Apricots}

\section{Recommended transport conditions:}

- Desired transit temperature: $32^{\circ} \mathrm{F}\left(0^{\circ} \mathrm{C}\right)$

- Desired relative humidity: 90 to 95 percent

- Highest freezing point: $30.1^{\circ} \mathrm{F}\left(-1.1^{\circ} \mathrm{C}\right)$

Apricots should be firm when shipped, so they will have a 1- to 2-week shelf life. Precool to the desired transit temperature. Some shippers use forced-air coolers, while others room cool their fruit. Apricots may be shipped with other tree fruit commodities from the same or nearby packing houses. If apricots are shipped in mixed loads that are top-iced, ice should not contact the apricots.

\section{Recommended loading methods:}

- Fiberboard boxes-Boxes of apricots generally are unitized on wood pallets. Secure the boxes with straps or plastic netting. If the apricots are not precooled to the transit temperature, place fiberboard strips between the stacks of boxes on the pallet so that cold air may circulate freely around them. If the weather is very hot and the trailer has flat sidewalls, center-load the pallets to prevent the transfer of heat from the walls to the fruit (figure 12b).

\section{Artichokes}

\section{Recommended transport conditions:}

- Desired transit temperature: $32^{\circ} \mathrm{F}\left(0^{\circ} \mathrm{C}\right)$

- Desired relative humidity: 95 to 100 percent

- Highest freezing point: $29.9^{\circ} \mathrm{F}\left(-1.2^{\circ} \mathrm{C}\right)$

- Top- or package-ice $O K$

Precool artichokes as soon as possible after harvest to reduce wilting, weight loss, discoloration, and decay. Use top-ice to prevent wilting or loss of turgidity and to keep the buds near the desired transit temperature for added shelf life. The marketability of artichokes is reduced by bruising or freezing. Severe freezing turns the buds black and slight freezing causes skin breaks and blisters.

\section{Recommended loading methods:}

- Fiberboard boxes-Most artichokes are packed in waxed fiberboard boxes which are stacked on their bottoms either lengthwise or crosswise on pallets. See figure 12 for unit load patterns.

\section{Asparagus}

\section{Recommended transport conditions:}

- Desired transit temperature: $32^{\circ}$ to $35^{\circ} \mathrm{F}\left(0^{\circ}\right.$ to $\left.2^{\circ} \mathrm{C}\right)$

- Desired relative humidity: 95 to 100 percent

- Highest freezing point: $30.9^{\circ} \mathrm{F}\left(-0.6^{\circ} \mathrm{C}\right)$

Asparagus is highly perishable. Speed and care are required during handling and transit to prevent excessive loss of quality. As soon as asparagus is cut, its natural sugars, flavor, and vitamin $\mathrm{C}$ begin to diminish rapidly, particularly at temperatures above $36^{\circ} \mathrm{F}$ $\left(2^{\circ} \mathrm{C}\right)$. Hydrocooling is the most desirable method of precooling.

Asparagus is usually packed in bunches and set upright in the shipping container to prevent bruising and curling of the tender tops. 
To prevent moisture loss and preserve crispness during transit, place pressed paperboard or other water-retaining material in the bottom of the pyramid-shaped wooden box or waxed corrugated fiberboard box.

A modified atmosphere of about 7 percent $\mathrm{CO}_{2}$ is beneficial in preventing decay and toughening of fresh asparagus. This is especially true if temperature control cannot be brought below $41^{\circ} \mathrm{F}\left(5^{\circ} \mathrm{C}\right)$.

\section{Recommended loading methods:}

- Nailed wooden boxes (pyramid-shaped)Load boxes lengthwise on their bottoms and stack in register. The slope of the pyramid allows open space for continuous lengthwise air channels on each layer in hand-stacked loads. For palletized loads, use a center-load pattern as shown in figure $12 \mathrm{~b}$.

- Fiberboard boxes (waxed corrugated) Load boxes lengthwise or crosswise on their bottoms and palletize. Use a center-load pattern as shown in figure $12 \mathrm{~b}$.

\section{Avocados}

\section{Recommended transport conditions:}

- Desired transit temperature:

Cold-tolerant varieties:

Such as Lula and Booth No. 8

$40^{\circ} \mathrm{F}\left(4^{\circ} \mathrm{C}\right)$

Cold-intolerant varieties:

All West Indian varieties, which include Fuchs, Pollack, and Walden $55^{\circ} \mathrm{F}\left(13^{\circ} \mathrm{C}\right)$

- Desired relative humidity:

85 to 90 percent

- Highest freezing point:

$31.5^{\circ} \mathrm{F}\left(-0.3^{\circ} \mathrm{C}\right)$

A few varieties, such as Fuerte, are best shipped at $45^{\circ} \mathrm{F}\left(7^{\circ} \mathrm{C}\right)$. Gradual ripening of avocados may occur at temperatures as low as $45^{\circ} \mathrm{F}\left(7^{\circ} \mathrm{C}\right)$. The rate of ripening and softening of the fruit increases as the temperature rises. Therefore, it is important to precool avocados before loading. Below recommended temperatures, avocados are susceptible to chilling injury. Common symptoms of chilling injury are a grayish- brown discoloration of the flesh, scalding and/or pitting of the skin, and failure of the fruit to ripen satisfactorily after storage or transit. At temperatures higher than recommended, anthracnose or black spot can become serious disorders.

\section{Recommended loading methods:}

- Fiberboard boxes-Both California and Florida shippers use fiberboard boxes for packing avocados. Shippers in both areas predominantly use a one- or two-layer box, and generally palletize their avocados. For hand-stacked loads, use an airflow pattern (figure 10). For transport in extremely cold weather, center-load pallets in vehicles without ribbed walls to prevent chilling injury (figure 12b).

\section{Bananas}

\section{Recommended transport conditions:}

- Desired transit temperature: $56^{\circ}$ to $58^{\circ} \mathrm{F}\left(13^{\circ}\right.$ to $\left.14^{\circ} \mathrm{C}\right)$

- Desired relative humidity: 90 to 95 percent

- Highest freezing point: $30.6^{\circ} \mathrm{F}\left(-0.8^{\circ} \mathrm{C}\right)$

Bananas are imported into the United States year-round from various Central and South American countries. The Cavendish variety is most commonly imported. Bananas are shipped green and ripened at destination. They are very temperature sensitive; lower than desired temperatures will cause chilling injury, and higher than desired temperatures may cause rapid and improper ripening. Proper air circulation is required to maintain uniform temperatures throughout the load, since fluctuating temperatures are detrimental. Provide a fresh air vent to prevent ethylene gas buildup inside the trailer which will cause premature ripening. Also, do not ship bananas with other produce that is not temperature compatible or that produces high amounts of ethylene.

\section{Recommended loading methods:}

- Corrugated fiberboard boxes-Nearly all bananas are packed in heavy duty, plastic 
film-lined fiberboard boxes at the country of origin. The gross weight of the boxes is 40 pounds $(18 \mathrm{~kg})$. They then are transported to the United States in refrigerated containers or on break-bulk ships under carefully controlled temperature and humidity conditions.

Since bananas are easily bruised, do not throw or drop the boxes during handling. Place the boxes on their bottoms, and do not invert or stack them on their sides. If not palletized, load the boxes crosswise or lengthwise and stack tightly together to get a dense load. In extremely cold weather, use floor racks or pallets in vehicles without deep Trail floors to prevent freezing or chilling injury. If the walls are not grooved, centerload pallets off the walls (figure 12b). Handstack boxes in an offset by layers pattern (figure $7 \mathrm{a}$ ) to reduce contact with the walls.

\section{Beans (green, snap, or pole)}

\section{Recommended transport conditions:}

- Desired transit temperature: $40^{\circ}$ to $45^{\circ} \mathrm{F}$ ( $4^{\circ}$ to $7^{\circ} \mathrm{C}$ )

- Desired relative humidity: 95 percent

- Highest freezing point: $30.7^{\circ} \mathrm{F}\left(-0.7^{\circ} \mathrm{C}\right)$

Green or snap beans are highly susceptible to chilling injury which predisposes them to russeting and other discoloration. Temperatures in the $40^{\circ}$ to $45^{\circ} \mathrm{F}\left(4^{\circ}\right.$ to $\left.7^{\circ} \mathrm{C}\right)$ range are considered best for shipping beans, even though some varieties may incur some chilling injury after several days at $45^{\circ} \mathrm{F}\left(7^{\circ} \mathrm{C}\right)$. At temperatures above $50^{\circ} \mathrm{F}\left(10^{\circ} \mathrm{C}\right)$, beans may decay rapidly. Precool beans before shipment but do not pack wet, as this will increase the chance of russeting and decay.

Use of a controlled atmosphere in the 2 to 3 percent oxygen and 5 to 10 percent carbon dioxide ranges will help retard yellowing of green beans. Green beans also are sensitive to ethylene and should not be shipped with ethylene producers.

\section{Recommended loading methods:}

Stack and load containers of green beans to allow maximum air circulation for respiration heat removal.

- Wirebound crates - Load wirebound crates lengthwise on their bottoms in an airflow pattern (figure 11).

- Fiberboard boxes - Load fiberboard boxes in an airflow pattern (figure 10). Increasingly, fiberboard boxes and wirebound crates of beans are palletized. Pallet patterns shown in figures $12 \mathrm{a}, \mathrm{b}$, or $\mathrm{c}$ allow good air circulation if pallets are properly secured.

\section{Beans (lima, in pods)}

\section{Recommended transport conditions:}

- Desired transit temperature: $41^{\circ}$ to $43^{\circ} \mathrm{F}\left(5^{\circ}\right.$ to $\left.6^{\circ} \mathrm{C}\right)$

- Desired relative humidity: 95 percent

- Highest freezing point: $31^{\circ} \mathrm{F}\left(-0.6^{\circ} \mathrm{C}\right)$

Fresh lima beans in pods will keep from 5 to 7 days if held and shipped within the desired temperature range. Higher holding temperatures will greatly reduce the market life of the beans.

Precool lima beans immediately after harvest, preferably by hydrocooling. The pods are susceptible to chilling injury below the recommended transit temperature. Chilling injury results in rusty-brown specks on the pods.

\section{Recommended loading methods:}

- Wirebound crates and waxed fiberboard boxes-Hand-stack boxes and crates in an airflow pattern (figures 10 and 11).

- Palletized loads-See figure 12 for illustrations of unit load patterns.

\section{Beets}

\section{Recommended transport conditions:}

- Desired transit temperature: $32^{\circ} \mathrm{F}\left(0^{\circ} \mathrm{C}\right)$

- Desired relative humidity: 98 to 100 percent 
- Highest freezing point

Tops, $31.3^{\circ} \mathrm{F}\left(-0.4^{\circ} \mathrm{C}\right)$

Roots, $30.3^{\circ} \mathrm{F}\left(-0.9^{\circ} \mathrm{C}\right)$

- Top-ice $O K$

Beets are shipped bunched with tops or loosely packed without tops. Those shipped in bunches are highly perishable because of the heat generated by the tops. They should be both package- and top-iced for maximum refrigeration and moisture retention. The leaves of bunched beets are especially susceptible to bacterial soft rot. Transit and marketing losses caused by this disease can be controlled by rapid precooling and maintenance of temperature at $32^{\circ} \mathrm{F}\left(0^{\circ} \mathrm{C}\right)$.

Late-crop beets are topped and may be shipped immediately or stored for later shipment. They are fairly decay resistant as long as their skins are not broken and cool temperatures are maintained. However, it is desirable to top-ice long distance shipments in hot weather.

\section{Recommended loading methods:}

- Bunched in wirebound crates - Load crates lengthwise on their sides. If top-iced, stack directly on top of each other and leave 1 inch $(2.5 \mathrm{~cm})$ or more between the lengthwise rows for ice to fill (see figure 12). If not top-iced, precool the beets, and use an airflow loading pattern (figure 11).

- Topped in wirebound crates-Hand-stack crates of topped beets in an airflow pattern (figure 11). If beets are top-iced, see figure 16 .

- Palletized-See "Unit and Pallet Loads" in section IV, and figure $12 \mathrm{~b}$.

\section{Beet Tops}

Beet tops have essentially the same transit and handling requirements as fresh spinach. See "Spinach" in this section.

\section{Blackberries}

\section{Recommended transport conditions:}

- Desired transit temperature: $31^{\circ}$ to $32^{\circ} \mathrm{F}\left(-0.6^{\circ}\right.$ to $\left.0^{\circ} \mathrm{C}\right)$

- Desired relative humidity: 90 to 95 percent
- Highest freezing point: $30.5^{\circ} \mathrm{F}\left(-0.8^{\circ} \mathrm{C}\right)$

Fresh blackberries are highly perishable. They usually are not shipped over long distances by truck since their shelf life is limited to a few days. Maintaining their temperature near the desired $32^{\circ} \mathrm{F}\left(0^{\circ} \mathrm{C}\right)$ is very important. An atmosphere of 10 to 20 percent carbon dioxide $\left(\mathrm{CO}_{2}\right)$ will help to retard decay.

\section{Recommended loading methods:}

- Fiberboard trays - Corrugated fiberboard trays usually interlock with the trays above. Hand-stack trays lengthwise on their bottoms with space between the rows for airflow. Place wood strips crosswise about every fourth layer for stabilization.

Most shippers palletize the trays of berries to minimize handling. Strap the trays securely to the pallets. Center-load the pallets, two-wide, and brace away from the walls, so that air can circulate around the load and eliminate the conduction of heat from the trailer walls to the fruit. Major shippers enclose the pallet loads of berries with airtight plastic bags and inject a modified atmosphere for increased protection against decay and extended shelf life (figures $12 \mathrm{~b}$ and 17).

\section{Blueberries}

\section{Recommended transport conditions:}

- Desired transit temperature: $31^{\circ}$ to $32^{\circ} \mathrm{F}$

- Desired relative humidity: 90 to 95 percent

- Highest freezing point: $29.7^{\circ} \mathrm{F}\left(-1.3^{\circ} \mathrm{C}\right)$

Blueberries are very temperature sensitive. Temperatures much above the desired holding temperature cause over-ripening, shriveling, and loss of shelf life. Avoid moisture on berries caused by condensation or other sources, while in transit. A minimum of handling, close temperature control, and expedited shipment and marketing are essential for successful sales since blueberries have a 


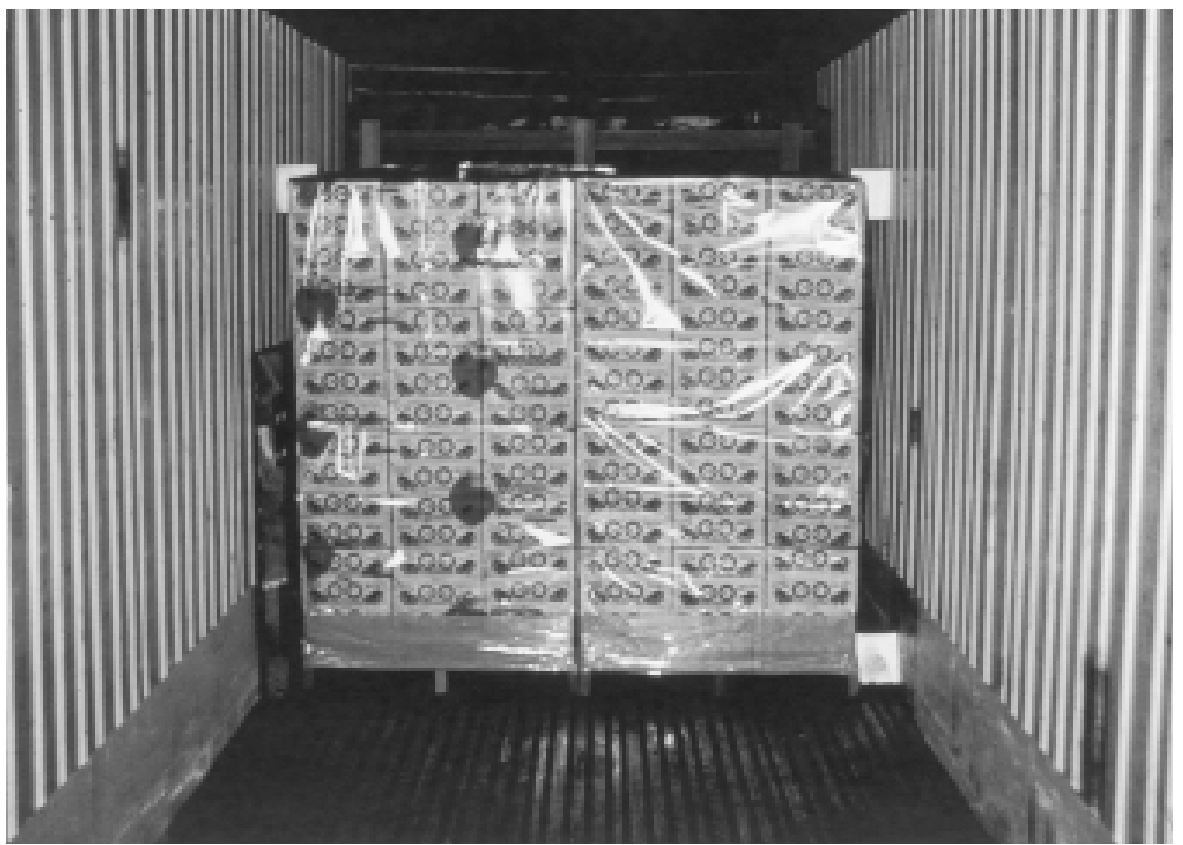

Figure 17.

A palletized load of strawberries, centerloaded. (Note: Each pallet load is enclosed in an airtight plastic bag injected with a modified atmosphere.)

shelf life of only about 2 weeks under optimum conditions. Modifying the atmosphere with $\mathrm{CO}_{2}$ in conjunction with refrigeration is effective in retarding decay in blueberries but may result in off-flavors.

\section{Recommended Loading Methods:}

- Fiberboard Trays-Blueberries are generally packed in film-covered pint- (0.47-1) sized containers. A plastic film cap is tightly secured on each container by a rubber band. Berries also may be packed in clear clam shell container. Twelve containers of berries are packed in a fiberboard tray. The trays are nearly always palletized for shipment. Center-load the pallets, and brace away from the wall, eliminating the conduction of heat from the trailer walls to the fruit (figure $12 b)$.

\section{Broccoli}

\section{Recommended transport conditions:}

- Desired transit temperature: $32^{\circ} \mathrm{F}\left(0^{\circ} \mathrm{C}\right)$

- Desired relative humidity: 95 to 100 percent

- Highest freezing point: $30.9^{\circ} \mathrm{F}\left(-0.6^{\circ} \mathrm{C}\right)$

- Top- and/or package-ice desirable

The respiration rate of broccoli is among the highest for vegetables. Therefore, refrigera- 
tion at or just above the desired transit temperature is required at all times. Exposing broccoli buds to temperatures above $50^{\circ} \mathrm{F}$ $\left(10^{\circ} \mathrm{C}\right)$ for only a short while will result in yellowing and reduced marketability. Provide fresh air exchange in the trailer to prevent anaerobic respiration and undesirable odors. Broccoli is sensitive to ethylene, so do not ship it with fruit, such as apples or pears, that produce substantial amounts of ethylene, because this gas will cause yellowing of the buds.

\section{Recommended loading methods:}

Broccoli is usually packed in waxed fiberboard boxes with crushed ice. After the boxes are loaded, top-ice the load.

- Fiberboard boxes-Load boxes lengthwise on their bottoms. Align rows with space between them for top-ice (figure 16). When the boxes have top and bottom ventilation slots, stack them in register, so that melt-water from the ice can run down through the product. Load hand-stacked boxes that are not top-iced in an airflow pattern (figure 10). Load top-iced, palletized loads of broccoli in any of the unit load patterns shown in figure 12 .

Note: If shrink film is used to secure the pallet loads, make sure the film does not cover the top, so melt-water can filter down through the broccoli.

\section{Brussels Sprouts}

\section{Recommended transport conditions:}

- Desired transit temperature: $32^{\circ} \mathrm{F}\left(0^{\circ} \mathrm{C}\right)$

- Desired relative humidity: 95 to 100 percent

- Highest freezing point: $30.5^{\circ} \mathrm{F}\left(-0.8^{\circ} \mathrm{C}\right)$

- Top- and/or package-ice OK

Keep brussels sprouts near the desired $32^{\circ} \mathrm{F}$ to attain the maximum shelf life of 3 to 5 weeks. At $41^{\circ} \mathrm{F}$ the deterioration rate of brussels sprouts doubles. Do not ship them with ethylene-producing fruit, because brussels sprouts will yellow. Use perforated plas- tic package liners to help prevent moisture loss from transpiration. A controlled or modified atmosphere of 2.5 to 5 percent oxygen and 5 to 7.5 percent carbon dioxide atmosphere helps maintain the quality of brussels sprouts at $41^{\circ} \mathrm{F}$ or $50^{\circ} \mathrm{F}$, but not at $32^{\circ} \mathrm{F}$.

\section{Recommended loading methods:}

Brussels sprouts are shipped mostly in waxed fiberboard cartons with package- or top-ice. Use the same loading procedures as those for broccoli. See preceding entry, "Broccoli."

\section{Cabbage}

\section{Recommended transport conditions:}

- Desired transit temperature: $32^{\circ} \mathrm{F}\left(0^{\circ} \mathrm{C}\right)$

- Desired relative humidity: 98 to 100 percent

- Highest freezing point: $30.4^{\circ} \mathrm{F}\left(-0.9^{\circ} \mathrm{C}\right)$

Cabbage is less perishable than many other leafy vegetables. Wilting from moisture loss is the main cause of damage during handling and transporting. Stored cabbage is less likely to wilt during transit than new cabbage. Except for a few new crop shippers, most shippers do not top-ice cabbage. Stored cabbage should not be top-iced. Several kinds of decay, such as bacterial soft rot and watery soft rot, may damage cabbage during transit if the desired temperature is not maintained.

\section{Recommended loading methods:}

- Wirebound boxes - Load boxes lengthwise on their bottoms. Most shippers offset the crates by layers to take up slack space and stabilize the load (figure 7a). Use an airflow pattern (figures 10 and 11) for crates of new cabbage that are not top-iced. If top-iced, load the crates lengthwise in rows with the slack space evenly divided between the rows (figure 16).

- Fiberboard boxes - Load boxes lengthwise on their bottoms in an airflow pattern (figure 10). For palletized loads, see figure 12 . 


\section{Cantaloupes}

\section{Recommended transport conditions:}

- Desired transit temperature: $36^{\circ}$ to $41^{\circ} \mathrm{F}\left(2^{\circ}\right.$ to $\left.5^{\circ} \mathrm{C}\right)$

- Desired relative humidity: 95 percent

- Highest freezing point: $29.9^{\circ} \mathrm{F}\left(-1.2^{\circ} \mathrm{C}\right)$

- Top-ice $O K$

After harvest, cantaloupes are forced-air or hydro-cooled to prevent them from becoming soft during long-distance transport. Although they are chill sensitive, cantaloupes are not harmed by extended contact with ice. Up to $10 \mathrm{lbs}(4.5 \mathrm{~kg})$ of crushed ice may be placed in boxes of cantaloupes after they are packed. Or, the loads may be top-iced if the cantaloupes are packed in moisture resistant boxes.

Cantaloupes picked at the hard-ripe stage of maturity are subject to chilling if held at temperatures below $36^{\circ} \mathrm{F}\left(2.2^{\circ} \mathrm{C}\right)$ for longer than 1 week. For normal truck shipments of less than 1 week, temperatures between $32^{\circ}$ and $34^{\circ} \mathrm{F}\left(0^{\circ}\right.$ to $\left.1^{\circ} \mathrm{C}\right)$ will not be harmful. Cantaloupes produce ethylene, so do not ship in mixed loads with ethylene-sensitive products such as green leafy vegetables.

\section{Recommended loading methods:}

- Fiberboard boxes-Stack boxes holding 9 to 23 cantaloupes each, six or seven layers high on pallets. Load the pallets, two across, the width of the truck. If top- or package-ice is used, the boxes must be moisture resistant, and floor drains should be open so that meltwater will not accumulate on the trailer floor. See figure 12 for pallet loading patterns.

\section{Carrots}

\section{Recommended transport conditions:}

- Desired transit temperature: $32^{\circ} \mathrm{F}\left(0^{\circ} \mathrm{C}\right)$

- Desired relative humidity: 98 to 100 percent
- Highest freezing point:

$29.5^{\circ} \mathrm{F}\left(-1.4^{\circ} \mathrm{C}\right)$

- Top-ice $O K$

Hydrocool carrots after harvest to ensure an adequate shelf life. Top-ice topped carrots for moisture retention. Carrots are shipped to market loose in bulk bags or fiberboard boxes or packed in consumer size plastic bags within larger mesh bags or in fiberboard boxes. Do not ship carrots with ethylene-producing commodities, because this will cause the carrots to have a bitter flavor.

\section{Recommended loading methods:}

- Open mesh or plastic film bags-Carrots in bags usually are stacked so that, when loaded, the carrots are in a vertical position. Load hand-stacked bags in rows with spaces between for top-ice. Wrap palletized loads with net, or strap for stability. See figure 12 for pallet load patterns.

- Corrugated fiberboard boxes (waxed) Carrots usually are packed horizontally in fiberboard boxes. Hand-stack boxes lengthwise on their bottoms in an airflow pattern (figure 10). Column-stack boxes loaded on pallets or slipsheets in the lower layers to retain their strength. Cross-stack the boxes in the upper layers for stability. See figure 12 for pallet load patterns.

\section{Cauliflower}

\section{Recommended transport conditions:}

- Desired transit temperature: $32^{\circ} \mathrm{F}\left(0^{\circ} \mathrm{C}\right)$

- Desired relative humidity: 95 to 98 percent

- Highest freezing point: $30.6^{\circ} \mathrm{F}\left(-0.8^{\circ} \mathrm{C}\right)$

\section{- Top-ice $O K$}

Precool cauliflower by vacuum or hydro methods before loading. To control decay, keep cauliflower below $40^{\circ} \mathrm{F}\left(4^{\circ} \mathrm{C}\right)$. If cauliflower is packed in moisture resistant boxes, it can be top-iced. Take care not to bruise the buds or heads during loading and handling. 


\section{Recommended loading methods:}

- Corrugated fiberboard boxes-Hand-stack boxes in an airflow pattern (figure 10). Most West Coast loads are packed in single-layer boxes and palletized. Do not load the pallets so high that the top layer of boxes compress the air-delivery chute and restrict airflow. This may result in poor air circulation and warm or freezing spots in the load. See figure 12 for pallet loading patterns.

- Wirebound crates-Hand-stack crates in an airflow pattern (figures 10 and 11).

\section{Celery}

\section{Recommended transport conditions:}

- Desired transit temperature: $32^{\circ} \mathrm{F}\left(0^{\circ} \mathrm{C}\right)$

- Desired relative humidity: 98 to 100 percent

- Highest freezing point: $31.1^{\circ} \mathrm{F}\left(-0.5^{\circ} \mathrm{C}\right)$

\section{- Top-ice $O K$}

Soon after harvest, precool celery to below $40^{\circ} \mathrm{F}\left(4^{\circ} \mathrm{C}\right)$ by either hydrocooling or vacuum cooling to limit decay. After harvest celery continues to grow, so pack it upright in the container. Sometimes celery is sleeved or bagged at the shipping point. The sleeves help retain moisture and prevent wilting which is a main cause of deterioration. Some shippers who use wirebound crates top-ice their celery, but this practice is not required if the celery is sleeved.

\section{Recommended loading methods:}

-Wirebound crates - Load crates lengthwise on their sides to protect the stalks from damage and allow the celery to grow straight. Hand-stack topiced celery in rows with spaces between for topice to fill (figure 16). If not top-iced stack in an airflow pattern (figures 10 and 11).

- Fiberboard boxes-Most celery that is packed in fiberboard boxes is vacuum-cooled and, therefore, not top-iced. Load the boxes lengthwise on their sides. Load boxes packed with celery hearts lengthwise on their bottoms. In either case, load hand-stacked boxes in an airflow pattern (figure 10).
Considerable amounts of crated and boxed celery are palletized. Figure 18 shows a mixed palletized load of celery and green onions loaded in the recommended airflow pattern. See "Unit or Pallet Loads" section and figure $12 \mathrm{a}$.

\section{Cherries}

\section{Recommended transport conditions:}

- Desired transit temperature: Sweet cherries: $30^{\circ}$ to $32^{\circ} \mathrm{F}\left(-1^{\circ}\right.$ to $\left.0^{\circ} \mathrm{C}\right)$ Sour cherries: $32^{\circ} \mathrm{F}\left(0^{\circ} \mathrm{C}\right)$

- Desired relative humidity: 90 to 95 percent

- Highest freezing point: Sweet cherries: $28.8^{\circ} \mathrm{F}\left(-1.8^{\circ} \mathrm{C}\right)$ Sour cherries: $29.0^{\circ} \mathrm{F}\left(-1.7^{\circ} \mathrm{C}\right)$

Cherries are highly perishable, so refrigerate to the desired transit temperature before loading. In conjunction with refrigeration, consider using a modified atmosphere with up to 20 percent $\mathrm{CO}_{2}$ to maintain the quality of cherries during transit.

Washington and Oregon cherry shippers place a polyethylene bag liner in the box. Respiration of the fruit in the bag will build up a sufficient concentration of $\mathrm{CO}_{2}$ to retard decay and help maintain a fresh appearance. However, the liners should be slit at destination to eliminate gas buildup and off flavors. California shippers do not use box liners. Increasingly pallet lots of cherries enclosed in plastic bags and treated with a modified atmosphere are being shipped.

\section{Recommended loading methods:}

- Wooden lugs-Most cherries are volumefilled. Unitize on pallets, and secure with strapping or plastic netting. See figure 12 for pallet load patterns.

- Corrugated fiberboard boxes-Increasing amounts of cherries are shipped in fiberboard boxes. Like the wooden lugs, they may be secured to the pallets with vertical and horizontal bands or plastic netting. See "Unit or Pallet Loads" section and figure 12 for information on pallet loading. 


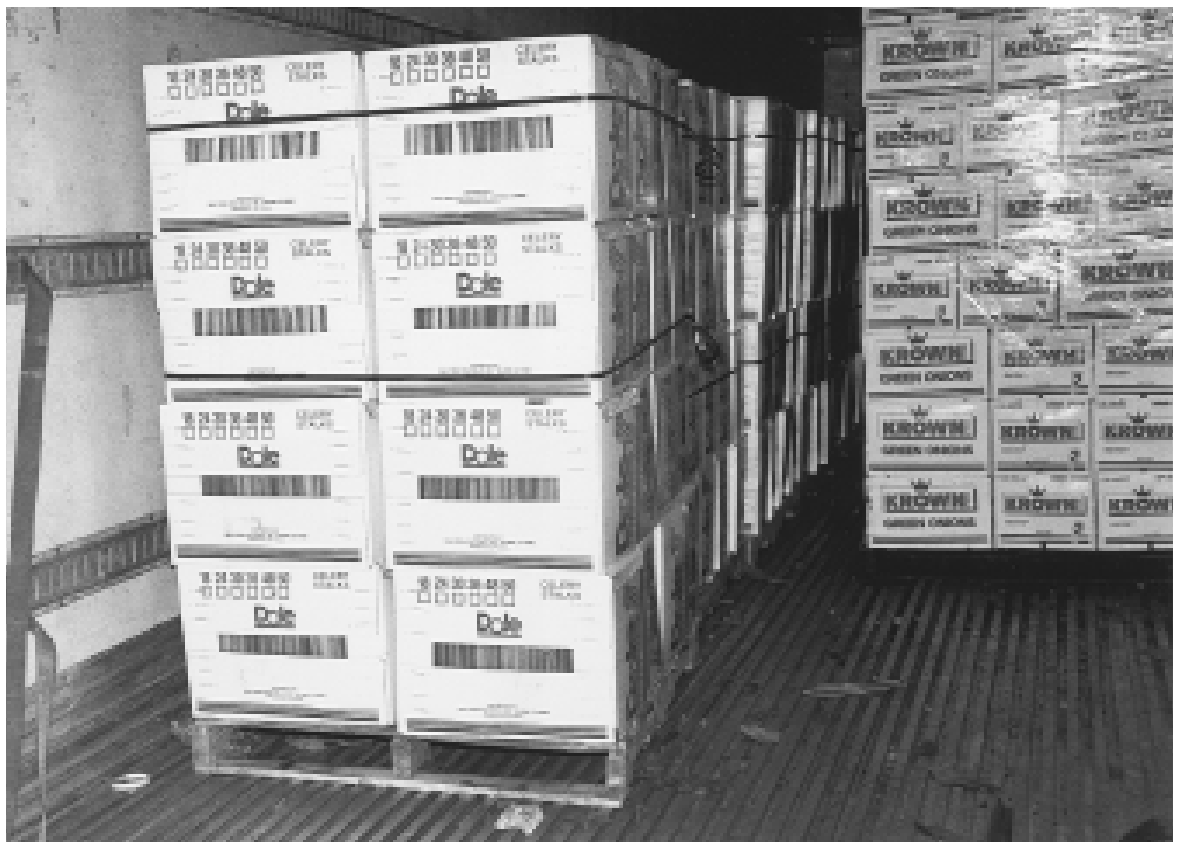

Figure 18.

A mixed palletized load

of celery and green

onions loaded in a unit load airflow pattern.

\section{Corn (sweet)}

\section{Recommended transport conditions:}

- Desired transit temperature: $32^{\circ} \mathrm{F}\left(0^{\circ} \mathrm{C}\right)$

- Desired relative humidity:

95 to 98 percent

- Highest freezing point:

$30.9^{\circ} \mathrm{F}\left(-0.6^{\circ} \mathrm{C}\right)$

\section{- Top-icing very desirable}

The sugar in freshly harvested sweet corn will turn to starch rapidly unless field heat is removed quickly. At room temperature, corn can lose 50 percent of its sugar in 24 hours. However, if the temperature is lowered to $32^{\circ} \mathrm{F}\left(0^{\circ} \mathrm{C}\right)$ soon after harvest, only 24 percent is lost in 4 days. Many newer varieties of corn retain their sugar content for longer periods than older varieties. In most growing areas, corn is hydrocooled, and in some areas, it is vacuum-cooled.

Corn has a high respiration rate and requires maximum refrigeration during transit. Topicing retains moisture and maintains a low temperature in corn during transit. If the corn is vacuum-precooled, top-icing is especially desirable to replace moisture lost from the husks. When the load is top-iced, set the thermostat at $36^{\circ} \mathrm{F}\left(2^{\circ} \mathrm{C}\right)$ so that the ice will melt. If the thermostat is set at or below freezing, ice may crust on top of the load and block air circulation and keep meltwater from cooling corn in the bottom of the load.

Prepackaging several ears of corn in filmcovered trays for retail at the grower level is a rapidly growing practice. The trays are 
subsequently packed in fiberboard boxes for shipment. Do not top-ice these boxes. If corn is not top-iced, ship it at $32^{\circ} \mathrm{F}$.

\section{Recommended loading methods:}

- Wirebound crates-The majority of Florida sweet corn is shipped in wirebound crates loaded lengthwise on their sides. Align rows, keeping adequate space between them to allow for top-ice (figure 16). Another loading pattern calls for loading the crates lengthwise on their sides with no space between rows in the first two or three layers. The upper layers have one less row and are offset over the bottom layers with several inches of space between rows. Place wooden strips horizontally across the top of each layer to prevent the crates from toppling and blocking the space between rows. This loading method allows a large volume of top-ice to get between the rows in the upper layers and melt water to run directly through the bottom layers.

- Fiberboard boxes-Load boxes lengthwise on their bottoms. Moisture-resistant fiberboard boxes have openings only in the top and bottom for top-ice melt-water to run down through the layers. Stack these boxes in register or squarely over each other so the melt-water can run down through all of the layers of the stack.

Load boxes or crates without top-ice in an airflow pattern (figures 10 and 11). Load pallets as shown in figure $12 \mathrm{a}$ or $12 \mathrm{~b}$ to assure maximum top-ice infiltration in topiced loads or air circulation in loads without top-ice.

\section{Cranberries}

\section{Recommended transit conditions:}

- Desired transit temperature: $36^{\circ}$ to $40^{\circ} \mathrm{F}\left(2^{\circ}\right.$ to $\left.4^{\circ} \mathrm{C}\right)$

- Desired relative humidity: 90 to 95 percent

- Highest freezing point: $30.4^{\circ} \mathrm{F}\left(-0.9^{\circ} \mathrm{C}\right)$

Cranberries are primarily grown in Wisconsin, Massachusetts, New Jersey, Oregon, and Washington, and are harvested and available for fresh distribution from September through December. Cranberries can be held at temperatures of $36^{\circ}$ to $40^{\circ} \mathrm{F}\left(2^{\circ}\right.$ to $\left.4^{\circ} \mathrm{C}\right)$ up to 4 months. Cranberries will tolerate temperatures as low as $32^{\circ} \mathrm{F}\left(0^{\circ} \mathrm{C}\right)$ for up to 2 weeks. However, exposure for longer periods could cause chilling damage resulting in discoloration and rubbery texture. Handle cranberries with care since they are susceptible to bruising. Precool cranberries to near $40^{\circ} \mathrm{F}\left(4^{\circ} \mathrm{C}\right)$ before loading, because the insulation effect of the packaging makes it difficult to lower temperature during transit.

\section{Recommended loading methods:}

- Fiberboard master cartons-Cranberries for the fresh market are packed in 1-lb $(0.45-\mathrm{kg})$ film bags or window boxes and shipped in master fiberboard containers that will hold 241 -lb packages. For handstacked loads, stack the master fiberboard cartons lengthwise on their bottoms in an airflow pattern (figure 10).

For palletized loads, center-load as shown in figure $12 b$.

\section{Cucumbers}

\section{Recommended transport conditions:}

- Desired transit temperature: $50^{\circ}$ to $55^{\circ} \mathrm{F}\left(10^{\circ}\right.$ to $\left.13^{\circ} \mathrm{C}\right)$

- Desired relative humidity: 95 percent

- Highest freezing point: $31.1^{\circ} \mathrm{F}\left(-0.5^{\circ} \mathrm{C}\right)$

Generally, cucumbers do not require precooling before transit. However, store them so that excess field heat will be removed within 24 hours after harvest, or yellowing will occur. Yellowing also may occur if cucumbers are shipped in mixed loads with tomatoes or other ethylene-producing products. Cucumbers are subject to chilling injury if held or transported for longer than 2 days at temperatures below $50^{\circ} \mathrm{F}\left(10^{\circ} \mathrm{C}\right)$. Decay is controlled by maintaining transit temperatures near desired levels. However, at higher temperatures bacterial diseases can be a problem. Cucumbers are very susceptible to shriveling, so keep humidity high during storage and transit. Also, cucumbers usually are waxed to prevent shriveling. 


\section{Recommended loading methods:}

- Fiberboard boxes-Most cucumbers are packed in various sizes of fiberboard boxes. Load hand-stacked boxes lengthwise on their bottoms in an airflow pattern (figure 10). Many shippers palletize their cucumbers. See "Unit or Pallet Loads" section for pallet loading patterns.

\section{Eggplants}

\section{Recommended transport conditions:}

- Desired transit temperatures: $46^{\circ}$ to $54^{\circ} \mathrm{F}$ ( $8^{\circ}$ to $12^{\circ} \mathrm{C}$ )

- Desired relative humidity: 90 to 95 percent

- Highest freezing point: $30.6^{\circ} \mathrm{F}\left(-0.8^{\circ} \mathrm{C}\right)$

Some eggplant fruit are subject to chilling injury at $50^{\circ} \mathrm{F}\left(10^{\circ} \mathrm{C}\right)$ and below. Surface scald or bronzing and pitting are symptoms of chilling injury. Chilled eggplants are subject to Alternaria rot when removed from storage or transit. Chilling sensitivity varies by season of harvest, variety, and maturity. Overmature fruit harvested in the fall is less sensitive to chilling than mature fruit harvested in the summer. Mature eggplants harvested midsummer are highly susceptible to decay at temperatures higher than $54^{\circ} \mathrm{F}$ $\left(12^{\circ} \mathrm{C}\right)$ and chilling injury below $50^{\circ} \mathrm{F}$ $\left(10^{\circ} \mathrm{C}\right)$. Eggplants shrivel very easily during transport and storage if the relative humidity is not kept at 90 percent.

\section{Recommended loading patterns:}

- Fiberboard boxes-Most eggplants are packed in fiberboard boxes. Generally, load hand-stacked boxes lengthwise on their bottoms in an airflow pattern (figure 10). Many shippers palletize their eggplant boxes eight per layer and five to six layers high. Load pallets in an off-wall pattern (figure 12b).

\section{Endive and Escarole}

\section{Recommended transport conditions:}

- Desired transit temperature: $32^{\circ} \mathrm{F}\left(0^{\circ} \mathrm{C}\right)$
- Desired relative humidity:

95 to 100 percent

- Highest freezing point:

$31.9^{\circ} \mathrm{F}\left(-0.1^{\circ} \mathrm{C}\right)$

- Top-ice desirable

Endive and escarole are highly perishable leafy vegetables, similar to lettuce, which require maximum refrigeration during transit. They have a high rate of respiration, so precool immediately after harvest by vacuum or hydrocooling. Endive and escarole often are shipped in mixed loads with other products, because most orders for these products are for less than truckload lots. Top-ice or package-ice is desirable. If topice is applied to the load, set the thermostat on the refrigeration unit at $36^{\circ} \mathrm{F}\left(2^{\circ} \mathrm{C}\right)$ so that the ice will melt slowly and run down through the load. If not top-iced, ship the product at $32^{\circ} \mathrm{F}\left(0^{\circ} \mathrm{C}\right)$.

\section{Recommended loading methods:}

- Fiberboard boxes (waxed) —LLoad the boxes lengthwise on their bottoms in an airflow pattern, if not top-iced (figure 10). If top-iced, stack the boxes lengthwise or crosswise in rows, directly on top of each other so the melt-water can run down through the top and bottom vent holes (figure 16).

- Wirebound crates-Load crates lengthwise on their bottoms in an airflow pattern (figures 10 and 11). If top-iced, stack the crates with slack space evenly divided between the rows (figure 16).

Use unit load patterns (figure 12a or b) for palletized loads of endive or escarole to assure space for air circulation or top-ice infiltration.

\section{Garlic (dry)}

\section{Recommended transport conditions:}

- Desired transit temperature: $32^{\circ}$ to $34^{\circ} \mathrm{F}\left(0^{\circ}\right.$ to $\left.1^{\circ} \mathrm{C}\right)$

- Desired relative humidity: 65 to 70 percent

- Highest freezing point: $30.5^{\circ} \mathrm{F}\left(-0.8^{\circ} \mathrm{C}\right)$ 
Garlic is usually shipped from storage at $32^{\circ} \mathrm{F}\left(0^{\circ} \mathrm{C}\right)$. In warm weather, take care to load the garlic promptly to reduce moisture condensation on the product. Load in an airflow pattern to remove any condensation that does occur. Garlic cloves sprout rapidly at temperatures above $40^{\circ} \mathrm{F}\left(4^{\circ} \mathrm{C}\right)$. Do not ship garlic in mixed loads with odor absorbing commodities. Do not allow ice to come in contact with garlic.

\section{Recommended loading methods:}

- Fiberboard boxes-Load the boxes lengthwise on their bottoms in an airflow pattern (figure 10). This pattern assures good ventilation of the load to remove condensation and maintain desired transit temperature. For palletized shipments, use load patterns shown in figures $12 \mathrm{a}$ and $\mathrm{b}$.

\section{Grapefruit}

\section{Recommended transport conditions:}

- Desired transit temperatures:

Arizona and California: $58^{\circ}$ to $60^{\circ} \mathrm{F}$ $\left(14^{\circ}\right.$ to $\left.16^{\circ} \mathrm{C}\right)$

Florida and Texas: Before January $1-60^{\circ} \mathrm{F}\left(16^{\circ} \mathrm{C}\right)$ After January $1-50^{\circ} \mathrm{F}\left(10^{\circ} \mathrm{C}\right)$

- Desired relative humidity: 85 to 95 percent

- Highest freezing point: $30^{\circ} \mathrm{F}\left(-1.1^{\circ} \mathrm{C}\right)$

Grapefruit are very susceptible to chilling injury, particularly early in the season. Chilling injury symptoms are pitting or physiological breakdown on the surface of the fruit which can be a means of entry for decay organisms. Many types of decay organisms can attack grapefruit, particularly during early- and late-season shipments. Most shippers treat their grapefruit with approved fungicides. Curing or preconditioning grapefruit can counteract some of the adverse effects of low temperature. To cure grapefruit, hold at $60^{\circ} \mathrm{F}\left(16^{\circ} \mathrm{C}\right)$ for 1 week. After curing, store or ship grapefruit at temperatures of $32^{\circ}$ to $34^{\circ} \mathrm{F}\left(0^{\circ}\right.$ to $\left.1^{\circ} \mathrm{C}\right)$ for up to 21 days. Cured grapefruit may be stored or shipped with oranges at low temperatures.
Ventilate grapefruit loads during transit in cool weather. However, during warm weather, refrigerate the loads.

CAUTION: $41^{\circ} \mathrm{F}\left(5^{\circ} \mathrm{C}\right)$ is the temperature at which the danger of chilling injury to grapefruit is the greatest.

\section{Recommended loading methods:}

- Fiberboard boxes (loose filled)_LLad boxes lengthwise or crosswise on their bottoms. Hand-stack loads in an airflow pattern (figure 10). Florida shippers mainly unitize their shipments on slipsheets. Many California, Arizona, and Texas shippers unitize their shipments on pallets. See figure 12 for unit load patterns.

- Fiberboard boxes (bag master)_Load boxes lengthwise or crosswise on bottoms. Hand-stack bag-master boxes in an airflow pattern (figure 10). Many bag-master boxes are unitized on slipsheets or pallets. Since most shippers do not precool their fruit, take extreme care in transporting grapefruit in bag masters. The fruit is packed in polyethylene film or mesh bags and packed in boxes which makes it more difficult to cool the fruit in transit. Use the unit load patterns in figure $12 \mathrm{a}$ or $\mathrm{b}$ for bag-master packed grapefruit that has not been precooled.

\section{Grapes}

\section{Recommended transport conditions:}

- Desired transit temperatures: American types - Catawba, Concord, etc.: $32^{\circ} \mathrm{F}\left(0^{\circ} \mathrm{C}\right)$

European types (vinifera)-Thompson seedless, Red Emperor, etc.: $31^{\circ} \mathrm{F}$ $\left(-0.5^{\circ} \mathrm{C}\right)$

- Desired relative humidity: American: 90 to 95 percent European: 85 percent

- Highest freezing point: American types: $29.7^{\circ} \mathrm{F}\left(-1.3^{\circ} \mathrm{C}\right)$ European types (vinifera): $28.1^{\circ} \mathrm{F}$ $\left(-2.2^{\circ} \mathrm{C}\right)$

Precool grapes to their desired transit temperature before loading, and maintain the temperature during transit. Normally, fumigate vinifera grapes with sulphur dioxide 
gas $\left(\mathrm{SO}_{2}\right)$ during storage and before shipment to control the spread of Botrytis (gray mold) and Cladosporium decays. This fumigation will not kill infections that started before harvest. For grapes that are packed for export, use top cushion pads that contain sodium bi-sulphite which will be slowly released during transportation. Do not ship grapes treated with $\mathrm{SO}_{2}$ with other products since the gas odor may be absorbed.

Do not ship grapes with green onions, as they may absorb the onion odor. Also, prevent grapes from coming in contact with ice.

WARNING: When using $\mathrm{SO}_{2}$ gas, take care to prevent injury to workers and equipment. $\mathrm{SO}_{2}$ fumes are toxic to humans and will corrode certain metals.

\section{Recommended loading methods:}

- Wood and kraft veneer, fiberboard, and polystyrene foam boxes - Load hand-stacked boxes lengthwise on their bottoms in an airflow pattern (figure 10). Most shipments of grapes are palletized. See figure 12 for pallet load patterns. Use patterns shown in figures $12 \mathrm{c}$ and $\mathrm{d}$ for export grapes loaded in van containers with bottom-air delivery systems.

\section{Kale}

\section{Recommended transport conditions:}

- Desired transit temperature: $32^{\circ} \mathrm{F}\left(0^{\circ} \mathrm{C}\right)$

- Desired relative humidity: 95 to 100 percent

- Highest freezing point: $31.1^{\circ} \mathrm{F}\left(-0.5^{\circ} \mathrm{C}\right)$

\section{- Top-ice $O K$}

Kale, a leafy vegetable, has a high rate of respiration. It requires maximum refrigeration during handling and transit to maintain its quality. When kale is transported or kept at temperatures above $32^{\circ} \mathrm{F}\left(0^{\circ} \mathrm{C}\right)$, it may temporarily appear to be in good condition. However, the higher temperatures will reduce its resistance to decay and yellowing of the leaves, and it will break down rapidly when displayed in stores.
To precool and to maintain crispness, pack crushed or slush-ice in each container of kale. Spread a liberal amount of top-ice over loads which are not prepackaged.

\section{Recommended loading methods:}

- Wirebound crates-Align the crates with space divided between the rows for top-ice to fill (figure 16). If not top-iced, load crates in an airflow pattern (figures 10 and 11).

- Fiberboard boxes (waxed and unwaxed) Load waxed boxes packed with loose kale in straight rows with space divided between the rows for top-ice to fill (figure 16).

Prepackaged kale needs cold air circulated to each box. Use an airflow pattern for hand-stacked loads (figure 10). For palletized loads going into a wide trailer, use the pallet loading patterns (figure 12a or b) to allow air to circulate around the product.

\section{Kiwi Fruit}

\section{Recommended transit conditions:}

- Desired transit temperature: $32^{\circ} \mathrm{F}\left(0^{\circ} \mathrm{C}\right)$

- Desired relative humidity: 90 to 95 percent

- Highest freezing point: $29.0^{\circ} \mathrm{F}\left(-1.7^{\circ} \mathrm{C}\right)$

Cool kiwi fruit to $32^{\circ} \mathrm{F}\left(0^{\circ} \mathrm{C}\right)$ as soon after harvest as possible, and maintain that temperature during transit. Take care to prevent kiwi fruit from being exposed to ethylene gas. Use electric forklift trucks to handle kiwi fruit, since they do not produce ethylene as propane-fueled trucks do. Do not ship kiwi fruit in mixed loads with products that generate ethylene, such as apples and other tree fruit.

\section{Recommended loading methods:}

- Wood trays and fiberboard boxes-Load trays and boxes lengthwise on their bottoms. Most boxes of kiwi fruit are palletized for shipment. See figure 12 for pallet loading patterns. 


\section{Lemons}

\section{Recommended transport conditions:}

- Desired transit temperature: $45^{\circ}$ to $55^{\circ} \mathrm{F}\left(7^{\circ}\right.$ to $\left.13^{\circ} \mathrm{C}\right)$

- Desired relative humidity: 85 to 90 percent

- Highest freezing point: $29.4^{\circ} \mathrm{F}\left(-1.4^{\circ} \mathrm{C}\right)$

Lemons are subject to chilling injury (pitting and physiological breakdown) if stored for long periods at temperatures below $58^{\circ} \mathrm{F}$ $\left(14^{\circ} \mathrm{C}\right)$. However, during domestic transit periods of several days, rot and mold are more likely to damage lemons than cold. For transit and storage periods up to 4 weeks, lemons may be held at any convenient temperature between $45^{\circ}$ and $55^{\circ} \mathrm{F}\left(7^{\circ}\right.$ to $\left.13^{\circ} \mathrm{C}\right)$ without incurring chilling injury. Lemons usually are shipped from cold storage and are near the desired transit temperature when loaded. They may be ventilated if outside temperatures fall within the desired temperature range.

\section{Recommended loading methods:}

- Corrugated fiberboard boxes - Nearly all lemons consumed in the United States are produced in Arizona and California. The lemons are usually packed in fiberboard boxes and palletized for shipment. See figure 12 for pallet loading patterns.

\section{Lettuce (head)}

\section{- Desired transit temperature:} $32^{\circ} \mathrm{F}\left(0^{\circ} \mathrm{C}\right)$

- Desired relative humidity: 98 to 100 percent

- Highest freezing point: $31.7^{\circ} \mathrm{F}\left(-0.2^{\circ} \mathrm{C}\right)$

Lettuce is one of the most perishable and easily damaged of all commercial vegetables. Individual lettuce heads usually are field packed unwrapped or wrapped in plastic film, then packed in fiberboard boxes. Vacuum-cool field-packed lettuce, and place in cold rooms until ready for loading. Or vacuum-cool the lettuce immediately before loading. Because it is difficult to cool lettuce in transit, take several product temperatures during loading to make sure that the lettuce is near the desired transport temperature. Lettuce is sensitive to ethylene gas, so do not load it with ethylene-producing commodities. In extreme temperatures, load lettuce up off the floor on pallets or floor racks and away from the side walls of the trailer to prevent warming or freezing. Do not ice lettuce.

\section{Recommended loading methods:}

- Fiberboard boxes - Lettuce boxes usually are unitized and mechanically loaded.

Many different types of load patterns are used, depending on the individual shipper's equipment. Since lettuce heads are of low density and high cube, there is a tendency to load it tightly, without air channels. Extremely tight loads, especially in trailers with flat walls, may overheat or freeze in extreme temperatures. During hot weather, load the lettuce on disposable wooden floor racks to allow additional airflow under the load. See figure 12 for pallet load patterns. In hot weather, use pattern $12 \mathrm{~b}$. Load hand-stacked boxes in an airflow pattern (figure 10).

\section{Lettuce (leaf)}

\section{Recommended transport conditions:}

- Desired transit temperature: $32^{\circ} \mathrm{F}\left(0^{\circ} \mathrm{C}\right)$

- Desired relative humidity: 98 to 100 percent

- Highest freezing point: $31.7^{\circ} \mathrm{F}\left(-0.2^{\circ} \mathrm{C}\right)$

All varieties of leaf lettuce (Bibb, Boston, butter, etc.) are very perishable and easily damaged. Precool leaf lettuce immediately after harvest by either vacuum or hydrocooling. Once lettuce is precooled, ship it as near to $32^{\circ} \mathrm{F}\left(0^{\circ} \mathrm{C}\right)$ as possible and at high relative humidity. At higher temperatures, the rate of respiration is high, and bruised areas will disease rapidly. Bacterial soft rot is the most serious lettuce disease. 
Recommended loading methods:

- Fiberboard boxes (waxed)_Load handstacked boxes lengthwise on their bottoms in an airflow pattern (figure 10). There are many kinds and sizes of fiberboard boxes used for shipping leaf lettuce. However, most shippers pack 12 or 24 bunches per box. If palletized, see figure 12 for loading patterns. Use the pattern shown in figure $12 \mathrm{~b}$ for shipments in extreme temperatures.

- Wirebound crates-Load crates lengthwise on their bottoms in an airflow pattern (figures 10 and 11).

\section{Limes}

\section{Recommended transport conditions:}

- Desired transit temperature: $48^{\circ}$ to $50^{\circ} \mathrm{F}\left(9^{\circ}\right.$ to $\left.10^{\circ} \mathrm{C}\right)$

- Desired relative humidity: 85 to 90 percent

- Highest freezing point: $29.1^{\circ} \mathrm{F}\left(-1.6^{\circ} \mathrm{C}\right)$

Limes are picked green and should remain green during marketing for best quality. After harvest, limes are sorted, packed and precooled to around $50^{\circ} \mathrm{F}\left(10^{\circ} \mathrm{C}\right)$ in refrigerated rooms. Limes are subject to attack by blue- and green-mold and stem-end rot. Limes picked when over-mature may develop stylar-end breakdown during transit. Green color is maintained better at lower temperatures, but pitting (chilling injury) may occur when limes are held at temperatures below $46^{\circ} \mathrm{F}\left(8^{\circ} \mathrm{C}\right)$.

\section{Recommended loading methods:}

- Fiberboard boxes-Load boxes lengthwise on their bottoms. Most limes are packed in a fiberboard box containing 10 pounds, but a few are still shipped in a 4/5-bushel fiberboard box. Load the 4/5-bushel boxes in an airflow pattern (figure 10) or palletized 9 per layer and 6 layers high. See figure 12 for pallet loading patterns.

\section{Mangoes}

\section{Recommended transport conditions:}

- Desired transit temperature: $55^{\circ} \mathrm{F}\left(13^{\circ} \mathrm{C}\right)$

- Desired relative humidity: 85 to 90 percent

- Highest freezing point: $30.3^{\circ} \mathrm{F}\left(-0.9^{\circ} \mathrm{C}\right)$

Generally, the best transit temperature for mangoes is $55^{\circ} \mathrm{F}\left(13^{\circ} \mathrm{C}\right)$. All mangoes are highly susceptible to chilling injury which is manifested as a gray scald-like discoloration of the skin often accompanied by pitting, uneven ripening, and poor flavor and color development. Some varieties are susceptible to chilling injury below $55^{\circ} \mathrm{F}\left(13^{\circ} \mathrm{C}\right)$. Other varieties can withstand transit temperatures down to $50^{\circ} \mathrm{F}\left(10^{\circ} \mathrm{C}\right)$ before sustaining chilling injury. Mangoes ripen slowly at $55^{\circ} \mathrm{F}$ $\left(13^{\circ} \mathrm{C}\right)$.

\section{Recommended Loading Methods:}

- Fiberboard boxes-Load boxes lengthwise on their bottoms in an airflow pattern with unobstructed lengthwise air channels (figure 10). Most Florida shippers palletize their mangoes, and load using the center-load pattern (figure $12 b$ ).

\section{Melons (Honeydew, Casaba, Crenshaw, Persian)}

\section{Recommended transport conditions:}

- Desired transit temperature: $45^{\circ}$ to $50^{\circ} \mathrm{F}\left(7^{\circ}\right.$ to $\left.10^{\circ} \mathrm{C}\right)$

- Desired relative humidity: 90 to 95 percent

- Highest freezing point: $30.5^{\circ} \mathrm{F}\left(-0.8^{\circ} \mathrm{C}\right)$

Melons are very sensitive to chilling injury (pitting and physiological breakdown), and are easily bruised. Temperatures below $45^{\circ} \mathrm{F}$ $\left(7^{\circ} \mathrm{C}\right)$ may result in sunken areas on the skin and eventual decay. 
NOTE: Research has shown that honeydew melons may be transported at $36^{\circ}$ to $41^{\circ} \mathrm{F}$ $\left(2^{\circ}\right.$ to $\left.5^{\circ} \mathrm{C}\right)$ if they are treated with 1,000 $\mathrm{p} / \mathrm{m}$ ethylene gas for 24 hours immediately after harvest and then cooled to these temperatures. For ethylene gas treatments to be effective, the melons must be above $70^{\circ} \mathrm{F}$ $\left(21^{\circ} \mathrm{C}\right)$. The gas may be applied before or after loading for more uniform ripening.

Precool honeydew melons before loading if they are extremely hot, over $80^{\circ} \mathrm{F}\left(27^{\circ} \mathrm{C}\right)$. The amount of precooling will depend on the initial temperature of the melons, the amount of intransit ripening desired and the capacity of the trailer's refrigeration system. Many packing sheds ship honeydews at around $80^{\circ} \mathrm{F}\left(27^{\circ} \mathrm{C}\right)$ to allow some ripening in transit.

Honeydews have a relatively low respiration rate and are not densely packed. Most modern refrigerated trailers should have the capacity for intransit temperature pull down provided the melons are loaded at or below the normal $80^{\circ} \mathrm{F}\left(27^{\circ} \mathrm{C}\right)$ shipping temperature, with good air circulation to all parts of the load.

\section{Recommended loading methods:}

- Corrugated fiberboard boxes-Most melon boxes are palletized. Five pallet load patterns are shown in figure 12. However, if the melons require intransit ripening, use the pattern shown in figure 12a to maximize air circulation in the load. Use an airflow pattern (figure 10) for hand-stacked loads.

\section{Mushrooms}

\section{Recommended transport conditions:}

- Desired transit temperature: $32^{\circ} \mathrm{F}\left(0^{\circ} \mathrm{C}\right)$

- Desired relative humidity: 95 percent

- Highest freezing point: $30.4^{\circ} \mathrm{F}\left(-0.9^{\circ} \mathrm{C}\right)$

Fresh mushrooms are highly perishable with a shelf life of about 1 week under optimum conditions. Prompt precooling after harvest and close temperature control during transit are essential. Mushrooms are easily bruised and should be handled carefully. Moisture from condensation or other sources should be avoided. Mushrooms are sensitive to water and may develop brown spots and decay rapidly if wet. Fresh mushrooms may be prepackaged in 8-, 12-, and 16-ounce $(0.23,0.34$, and $0.45 \mathrm{~kg})$ consumer packages, which are then packed in fiberboard trays. They also may be packed bulk in 10pound $(4.5 \mathrm{~kg})$ fiberboard trays, or in 3 pound $(1.4 \mathrm{~kg})$ wooden baskets or fiberboard boxes.

\section{Recommended loading methods:}

Nearly all mushrooms are palletized for shipment. See figures $12 \mathrm{a}$ and $\mathrm{b}$ for pallet loading patterns.

\section{Okra}

\section{Recommended transport conditions:}

- Desired transit temperature: $45^{\circ}$ to $50^{\circ} \mathrm{F}\left(7^{\circ}\right.$ to $\left.10^{\circ} \mathrm{C}\right)$

- Desired relative humidity: 90 to 95 percent

- Highest freezing point: $28.7^{\circ} \mathrm{F}\left(-1.8^{\circ} \mathrm{C}\right)$

Okra deteriorates rapidly and has a very high rate of respiration at warm temperatures. Okra has a shelf life of about 10 days. Do not top-ice, because this will cause water spotting at all temperatures. At temperatures below $45^{\circ} \mathrm{F}\left(7^{\circ} \mathrm{C}\right)$, okra is susceptible to chilling injury which is manifested by surface discoloration, pitting, and decay. Okra also is easily bruised, and bruised areas will blacken rapidly.

\section{Recommended loading methods:}

- Wirebound crates - Load crates lengthwise on their bottoms in an airflow pattern (figures 10 and 11).

- Fiberboard boxes - Load boxes lengthwise on their bottoms in an airflow pattern (figure 10). If palletized, use pallet load patterns (figure 12). 


\section{Onions (green), Shallots, and Leeks}

\section{Recommended transport conditions:}

- Desired transit temperature: $32^{\circ} \mathrm{F}\left(0^{\circ} \mathrm{C}\right)$

- Desired relative humidity: 95 to 100 percent

- Highest freezing point:

Onions (bunch or spring): $30.4^{\circ} \mathrm{F}\left(-0.9^{\circ} \mathrm{C}\right)$

Shallots (white leaf bare): $31.6^{\circ} \mathrm{F}\left(-0.2^{\circ} \mathrm{C}\right)$

Leeks (blanched stalk): $30.7^{\circ} \mathrm{F}\left(-0.7^{\circ} \mathrm{C}\right)$

- Top-ice and/or package-ice $O K$

Green onions and shallots are highly perishable and should be precooled soon after harvest. Crushed ice in the package and top-ice will help to retain moisture and crispness, and help reduce yellowing. Do not load leeks with figs or grapes since these products will absorb the leek odor. Odor from green onions is absorbed by corn, figs, grapes, mushrooms, and rhubarb.

\section{Recommended loading methods:}

- Fiberboard boxes (waxed)-Load boxes lengthwise or crosswise on their bottoms. Load with other commodities that require top-icing and leave space between rows of boxes or pallet loads for top-ice to fill (figure 16). If top-ice is not used, hand-stack loads in an airflow pattern (figure 10) to allow maximum ventilation. Load palletized boxes in an airflow pattern (figures 12a and 18).

- Wirebound crates-Load crates in the same way as fiberboard boxes.

\section{Onions (dry bulbs)}

\section{Recommended transport conditions:}

- Desired transit temperature: $32^{\circ}-45^{\circ} \mathrm{F}\left(0^{\circ}-7^{\circ} \mathrm{C}\right)$ storage varieties $45^{\circ}-60^{\circ} \mathrm{F}\left(7^{\circ}-15.5^{\circ} \mathrm{C}\right)$ fresh varieties

- Desired relative humidity: 65 to 70 percent

- Highest freezing point: $30.6^{\circ} \mathrm{F}\left(-0.8^{\circ} \mathrm{C}\right)$
Dry onions store well if held at the proper temperature and humidity and kept dry after they are cured. Higher temperatures will cause sprouting and decay. Onions removed from cold storage during warm weather tend to sweat on contact with warm humid air. Avoid these conditions by minimizing the time the onions are on an open dock or loading from enclosed docks. Further reduce condensation by precooling the vehicle before loading and maintaining adequate air circulation in the vehicle during transit. Dry onions are packaged in a variety of ways for shipment, including 25- and 50-pound (11.3 and $22.7 \mathrm{~kg}$ ) mesh or plastic bags, 40-pound $(18 \mathrm{~kg})$ fiberboard boxes and various sizes of consumer-size mesh and plastic bags in shipping boxes.

\section{Recommended loading methods:}

- Open mesh or plastic bags-Load bags lengthwise or crosswise on floor or pallets. Load away from the walls and floor in extremely hot or cold weather to prevent temperature damage. Wrap with net or strap loads to secure the onions to the pallet. Center-load the pallets to keep the onions away from the walls in extremely cold or hot weather (figure 12b).

- Fiberboard boxes - Load hand-stacked boxes lengthwise on their bottoms in an airflow pattern (figure 10). Or load the boxes lengthwise or crosswise on pallets, and load the pallets off the wall (figure 12b).

\section{Oranges}

\section{Recommended transport conditions:}

- Desired transit temperature:

Florida and Texas: $32^{\circ}$ to $34^{\circ} \mathrm{F}$

$\left(0^{\circ}\right.$ to $\left.1^{\circ} \mathrm{C}\right)$

California and Arizona: $38^{\circ}$ to $48^{\circ} \mathrm{F}$ $\left(3^{\circ}\right.$ to $\left.9^{\circ} \mathrm{C}\right)$

- Desired relative humidity: 85 to 90 percent

- Highest freezing point: Peel $29.7^{\circ} \mathrm{F}\left(-1.3^{\circ} \mathrm{C}\right)$ Flesh $30.6^{\circ} \mathrm{F}\left(-0.8^{\circ} \mathrm{C}\right)$

The preshipment handling of oranges varies by production area and season. Generally, 
the fruit is washed, waxed, treated, and packaged for shipment. Most shippers do not precool oranges; therefore, the fruit temperature at loading depends on ambient temperature. Oranges are precooled in some areas, particularly in California. It is important to precool oranges prepackaged in polyethylene or mesh consumer bags and shipped in master shipping cartons, since the packaging makes it very difficult to cool in transit.

California and Arizona oranges shipped at temperatures below $38^{\circ} \mathrm{F}\left(3^{\circ} \mathrm{C}\right)$ are susceptible to chilling injury and other rind disorders. Oranges from all citrus-producing areas are subject to blue- and green-mold rots. In addition, Florida and Texas fruit are susceptible to stem-end rot. Losses from decay can be reduced by decay inhibitors, careful handling to prevent skin breaks, and proper refrigeration.

\section{Recommended loading methods:}

- Fiberboard boxes-Load boxes lengthwise or crosswise on their bottoms. Load hand-stacked boxes in an airflow pattern (figure 10). This pattern allows cooling by the refrigeration system or by ventilation of outside air when the ambient temperatures are reasonably close to the desired transit temperature. Shipments also may be unitized on pallets or slipsheets. See figure 12 in "Unit or Pallet Loads" for pallet loading patterns.

- Bins - Some shippers pack oranges in pallet bins constructed of fiberboard, wood, or wire mesh. The oranges may be in bulk or in open mesh bags when packed in the bins. Stack these bins two-high in the truck. Bin loading patterns are the same as for pallets (figure 12). Take care not to block ventilation between the layers when stacking solid wall bins.

\section{Parsley}

\section{Recommended transport conditions:}

- Desired transit temperature: $32^{\circ} \mathrm{F}\left(0^{\circ} \mathrm{C}\right)$

- Desired relative humidity: 95 to 100 percent
- Highest freezing point:

$30^{\circ} \mathrm{F}\left(-1.1^{\circ} \mathrm{C}\right)$

- Top- or package-ice desirable

Parsley keeps well at $32^{\circ} \mathrm{F}\left(0^{\circ} \mathrm{C}\right)$ in combination with high humidity. Like all leafy vegetables, parsley has a high rate of respiration and its temperature must be lowered quickly to retard respiration and spoilage. Usually parsley is hydro- or vacuum-cooled and top- or package-ice is applied before shipment to maintain its crispness. It usually is ordered in small lots and shipped in mixed loads with other commodities. Parsley is sensitive to ethylene, so do not ship with ethylene-producing products.

\section{Recommended loading methods:}

- Fiberboard boxes (waxed) and wirebound crates-Load boxes and crates lengthwise on their bottoms. Load in rows across the trailer with space divided evenly between the rows for top-ice to fill (figure 16). For palletized loads, stack the containers lengthwise or crosswise on the pallets. Leave space between the pallet rows and walls for top-ice to fill (figure 12a).

\section{Parsnips}

\section{Recommended transport conditions:}

- Desired transit temperature: $32^{\circ} \mathrm{F}\left(0^{\circ} \mathrm{C}\right)$

- Desired relative humidity: 98 to 100 percent

- Highest freezing point: $30.4^{\circ} \mathrm{F}\left(-0.9^{\circ} \mathrm{C}\right)$

- Top- or package-ice desirable

Parsnips have transit and storage requirements similar to carrots. They are topped after harvest and will keep up to 4 months if held at $32^{\circ} \mathrm{F}\left(0^{\circ} \mathrm{C}\right)$ and a high relative humidity. Parsnips tend to shrivel from lack of moisture.

\section{Recommended loading methods:}

- Open mesh or plastic film bags-Parsnips are usually packaged in plastic film bags and shipped with ice. Stack bagged 
parsnips so that when loaded, the parsnips are in a vertical position. Stack the bags so that top-ice can infiltrate the load. Bagged parsnips are often palletized and top-iced. In this case, use a pallet loading pattern (figure 12a).

- Fiberboard boxes (waxed)-Hand-stack boxes lengthwise on their bottoms, in register, in rows across the truck. Divide the space evenly between the rows for top-ice to fill (figure 16). When palletized, columnstack the boxes in the lower layers to retain their strength. Cross-stack the upper layers to stabilize the pallet load. See figure 12 for pallet loading patterns.

\section{Peaches and Nectarines}

\section{Recommended transport conditions:}

- Desired transit temperature: $31^{\circ}$ to $32^{\circ} \mathrm{F}\left(-0.6^{\circ}\right.$ to $\left.0^{\circ} \mathrm{C}\right)$

- Desired relative humidity: 90 to 95 percent

- Highest freezing point: $30.4^{\circ} \mathrm{F}\left(-0.9^{\circ} \mathrm{C}\right)$

Peaches and nectarines are relatively tender fruits and bruise easily. They are usually harvested and shipped while still firm, so that physical injury will be minimized during transit and marketing. To delay ripening and retard decay, promptly hydrocool or cool with forced air to the desired transit temperature before loading.

\section{Recommended loading methods:}

- Corrugated fiberboard boxes-Load boxes lengthwise on their bottoms. Boxes are usually volume-filled with 25 to 30 pounds (11.3 to $17.2 \mathrm{~kg}$ ) of fruit. Most shippers unitize their fruit on disposable wooden pallets.

- Wooden or fiberboard lugs_-Load lugs lengthwise on their bottoms. The fruit is often packed in plastic trays, in either one or two layers, which are then packed in the lugs. The lugs are palletized.
If not precooled, load hand-stacked containers in an airflow pattern (figure 10). Centerload palletized containers (figure 12b).

\section{Pears}

\section{Recommended transport conditions:}

- Desired transit temperature: $32^{\circ} \mathrm{F}\left(0^{\circ} \mathrm{C}\right)$

- Desired relative humidity: 90 to 95 percent

- Highest freezing point: $29.2^{\circ} \mathrm{F}\left(-1.6^{\circ} \mathrm{C}\right)$

Precool pears as soon after harvest as possible to protect their shelf life. The storage life of pears ranges from 2 to 8 months, depending on variety. Extensive warming of pears starts the ripening process which cannot be reversed. Therefore, transport pears as close to the storage temperature as possible.

\section{Recommended loading methods:}

- Corrugated fiberboard boxes-Fiberboard boxes may be volume-filled, place-packed, or tight-filled (vibration settled) with the cover tightly secured with strapping material or staples. The boxes are usually unitized on disposable wooden pallets and secured by straps or netting. Load patterns for pallets are shown in figure 12. For handstacked loads, use a tight loading pattern if the pears are thoroughly precooled. If the pears are not precooled to near the desired transit temperature, load in an airflow pattern (figure 10).

\section{Peas (green and snow peas in pods)}

\section{Recommended transport conditions:}

- Desired transport temperature: $32^{\circ} \mathrm{F}\left(0^{\circ} \mathrm{C}\right)$

- Desired relative humidity: 95 to 98 percent

- Highest freezing point: Pods: $30.9^{\circ} \mathrm{F}\left(-0.6^{\circ} \mathrm{C}\right)$

Shelled peas: $29.9^{\circ} \mathrm{F}\left(-1.2^{\circ} \mathrm{C}\right)$

- Top- or package-ice required 
Fresh green peas are extremely perishable and require the utmost care to keep them in salable condition. To slow the changing of sugar to starch, lower and hold the temperature of the peas to near $32^{\circ} \mathrm{F}\left(0^{\circ} \mathrm{C}\right)$ immediately after harvest by vacuum- or hydrocooling. Top-ice after loading to help maintain a low temperature and the fresh appearance of the pods. With less-than-truckload shipments of peas and where top-icing is not feasible, pack the peas with crushed ice. Peas are ethylene-sensitive, so do not ship in mixed loads with ethylene-producing products.

\section{Recommended loading methods:}

- Wirebound crates-Hand-stack crates lengthwise or crosswise on their bottoms. Keep rows aligned, with space divided evenly in between for top-ice to fill (figure 16). When crates are palletized, use an off-wall pattern (figures $12 \mathrm{a}$ and $\mathrm{b}$ ) which allows maximum air circulation or top-ice infiltration.

- Fiberboard boxes (waxed)—Pack peas in waxed fiberboard containers that are well ventilated, with holes on all faces. Pack crushed ice with the peas. Load hand-stack boxes and pallets the same as wirebound crates.

\section{Peppers (sweet)}

- Desired transit temperature: $45^{\circ}$ to $55^{\circ} \mathrm{F}\left(7^{\circ}\right.$ to $\left.13^{\circ} \mathrm{C}\right)$

- Desired relative humidity: 90 to 95 percent

- Highest freezing point: $30.7^{\circ} \mathrm{F}\left(-0.7^{\circ} \mathrm{C}\right)$

Mature-green peppers held at temperatures below $45^{\circ} \mathrm{F}\left(7^{\circ} \mathrm{C}\right)$ will incur chilling injury. Peppers stored at chilling temperatures develop pitting, scald, and various decays. At temperatures above $55^{\circ} \mathrm{F}\left(13^{\circ} \mathrm{C}\right)$ peppers can decay quite rapidly. Peppers are sensitive to ethylene, which will hasten ripening, so do not ship with ethylene-producing products.

\section{Recommended loading methods:}

- Fiberboard boxes-Load boxes lengthwise on their bottoms. Hand-stack boxes in an airflow pattern (figure 10). Many shipments of peppers are palletized. See figure 12 for pallet loading patterns.

\section{Pineapples}

\section{Recommended transport conditions:}

- Desired transit temperatures:

Mature-green fruit, $50^{\circ}$ to $55^{\circ} \mathrm{F}$

$\left(10^{\circ}\right.$ to $\left.13^{\circ} \mathrm{C}\right)$

Ripe fruit, $45^{\circ} \mathrm{F}\left(7^{\circ} \mathrm{C}\right)$

- Desired relative humidity:

85 to 90 percent

- Highest freezing point: $30.0^{\circ} \mathrm{F}\left(-1.1^{\circ} \mathrm{C}\right)$

Mature-green pineapples are susceptible to chilling injury if exposed to temperatures below $50^{\circ} \mathrm{F}\left(10^{\circ} \mathrm{C}\right)$. Symptoms of chilling injury are impaired ripening, brown or dull shell color, water soaked flesh, wilting of the crown, green spotting, and failure to develop a good flavor. Chilled fruit is particularly subject to decay if not kept refrigerated.

\section{Recommended loading methods:}

- Fiberboard boxes-Load boxes lengthwise or crosswise on their bottoms. Boxes often have fiberboard inserts placed between individual fruit to prevent bruising during transit. In extremely cold or hot weather, load boxes in an offset-by-layers pattern (figure $7 a)$. This will reduce product contact with the vehicle walls and possible chilling or freezing injury, especially if the walls are flat. Center-load pallets away from the walls in extremely cold weather for the same reason (figure 12b).

\section{Plums and Fresh Prunes}

\section{Recommended transport conditions:}

- Desired transit temperature: $32^{\circ} \mathrm{F}\left(0^{\circ} \mathrm{C}\right)$

- Desired relative humidity: 90 to 95 percent

- Highest freezing point: $30.5^{\circ} \mathrm{F}\left(-0.8^{\circ} \mathrm{C}\right)$

Thoroughly precool plums and fresh prunes soon after harvest. Generally, plums and 
prunes are packed and placed in cold-storage rooms for precooling before shipment. Handle carefully, because bruising and skin breaks may result in decay and loss of quality.

\section{Recommended loading method:}

- Corrugated fiberboard boxes - Load boxes lengthwise or crosswise on their bottoms. A considerable amount of this fruit is tightfilled (vibration-settled in the boxes with the cover tightly fastened) to reduce fruit bouncing and rotation in the boxes from highway vibration. Fruit movement within the boxes results in discolored rings in the skin around individual fruit, known as "roller bruising." Also, some fruit is tray-packed in fiberboard boxes. The boxes then are unitized on disposable wooden pallets and secured with straps or netting material (figure 14). Figure 12 shows pallet loading patterns.

\section{Potatoes}

\section{Recommended transport conditions:}

- Desired transport temperature:

Early crop-for table, $50^{\circ}$ to $60^{\circ} \mathrm{F}$ $\left(10^{\circ}\right.$ to $\left.16^{\circ} \mathrm{C}\right)$

-for chipping, $65^{\circ}$ to $70^{\circ} \mathrm{F}$ $\left(18^{\circ}\right.$ to $\left.21^{\circ} \mathrm{C}\right)$

Late crop-for table, $40^{\circ}$ to $50^{\circ} \mathrm{F}$ $\left(4^{\circ}\right.$ to $\left.10^{\circ} \mathrm{C}\right)$

-for chipping, $50^{\circ}$ to $60^{\circ} \mathrm{F}$ $\left(10^{\circ}\right.$ to $\left.16^{\circ} \mathrm{C}\right)$

- Desired relative humidity: 90 percent

- Highest freezing point: $30.9^{\circ} \mathrm{F}\left(-0.6^{\circ} \mathrm{C}\right)$

Ventilation, heating, or cooling may be required for potatoes in transit depending on the time of year and outside temperature conditions.

Early crop, or new, potatoes are harvested and shipped from the southern States during the winter, spring, and summer. Because these potatoes are shipped before their skin has had time to set or mature, they are easily skinned and bruised. Broken skins open the way for decay organisms and tissue browning at the surface and lower the market value of the product. Potatoes, fortunately, have the inherent ability to seal skin breaks by producing suberin and wound periderm, which are essentially new skin. This self-healing process proceeds best at a high humidity and temperatures of $60^{\circ}$ to $70^{\circ} \mathrm{F}\left(16^{\circ}\right.$ to $\left.21^{\circ} \mathrm{C}\right)$. If newly harvested potatoes are to be in transit for more than 48 hours, the lower portion of this temperature range is recommended.

As a rule, early crop potatoes may be shipped satisfactorily under ventilation. Ventilation aids drying when weather permits. Load in an airflow pattern to ensure full ventilation of potatoes packed in fiberboard boxes (figure 10).

Late crop potatoes are harvested during the summer and fall. They are allowed a longer time to mature before being dug. Therefore, their skins are less prone to injury from handling. Because of their tougher skins and less skinning, they do not need the higher temperature and humidity for healing required by early crop potatoes.

Most late crop potatoes are grown and stored in the northern States. They are shipped from storage in the late fall, winter, and early spring. Since many shipments move through areas with subfreezing temperatures, heat is often needed when transporting late crop potatoes. Operate fans with the heating system to circulate the warmed air around the load.

CAUTION: Take care to vent all direct combustion heaters.

Freezing damage is most likely in bags of potatoes loaded directly on the truck floor and against the bottom sidewalls. Cushioning or padding material on the floor will help insulate the product in the bottom layers, and protect against bruising from overhead weight. However, do not use any material, such as straw, that will fill the floor grooves, because it will block warm-air circulation under the load. Several types of suitable floor padding materials are available from commercial sources. Loading potatoes on wood pallets with the stringers running lengthwise also provides a means of protecting the potatoes from freezing at floor level by allowing circulating air under the load. 
Ventilate loads of late crop potatoes when outside temperatures range between $40^{\circ}$ to $50^{\circ} \mathrm{F}\left(4^{\circ}\right.$ to $\left.10^{\circ} \mathrm{C}\right)$ by opening the vent doors. At temperatures below or above this range, only open vent doors slightly to avoid oxygen starvation of the load.

\section{Recommended loading methods:}

- Burlap and master bags-Most potatoes are packed in consumer bags of plastic film holding 5 or 10 pounds ( 2.3 or $4.5 \mathrm{~kg}$ ).

These, in turn, are packed in polyethylene or paper master bags holding 50 pounds (22.7

$\mathrm{kg}$ ) and palletized. Research has found that potatoes incur the most loading-related bruising when bags or boxes are dropped on hard floor or pallet surfaces. Significant increases in bruising damage were found when the drop heights exceeded 30 inches $(76 \mathrm{~cm})$.

Center-load pallets (figure 12b) in extreme cold weather to keep the potatoes away from the walls and prevent freezing or chill damage. Load hand-stacked bags in a pyramid pattern (figure $7 \mathrm{~b}$ ) to reduce wall contact.

- Corrugated fiberboard boxes-Stack boxes lengthwise or crosswise on their bottoms on the floor, or unitize on pallets. Hand-stack boxes of new potatoes in an airflow pattern (figure 10c) to allow intransit drying. Load boxes of potatoes shipped from storage in winter in an offset-by-layers pattern (figure

7a) to reduce contact of potatoes with the walls and chance of freezing. Center-load palletized boxes (figure 12b) for the same reason.

- Bulk potatoes for chipping-Most potatoes for chipping are shipped from storage in bulk loads. Always load and transport the potatoes at the same or slightly warmer temperature than the storage temperature, but never at colder temperatures. Handle the potatoes as gently as possible. Rough handling and improper temperatures may cause adverse chemical reactions which may increase the sugar content of the potatoes. This subsequently results in undesirable dark-colored chips. Truckers should carry an accurate thermometer for checking pulp temperatures of the potatoes. Bulk chipping potatoes usually are loaded with a bin-piler conveyor with a telescoping boom. They are unloaded with an industrial truck or by gravity flow.

Construct bulkheads of plywood or place bags of potatoes 2 to 4 feet $(0.6$ to $1.2 \mathrm{~m})$ from the rear doors of the trailers to contain the loose potatoes. Place heaters in this open space, when required.

Chipping potatoes shipped from far northern States in the winter require heating. Temperature controlled semi-trailers are preferred and predominantly used. If heaters are used, operate the fans at all times to circulate the heated air over and under the load.

A buildup of carbon dioxide $\left(\mathrm{CO}_{2}\right)$ and depletion of oxygen $\left(\mathrm{O}_{2}\right)$ may also result in off-colored chips. Therefore, allow a small amount of outside air to ventilate to the chipping potatoes at all times. Operate the fan to circulate fresh air to all parts of the load. Chipping potatoes should be processed as soon as possible after unloading.

\section{Radishes}

\section{Recommended transport conditions:}

- Desired transit temperature: $32^{\circ} \mathrm{F}\left(0^{\circ} \mathrm{C}\right)$

- Desired relative humidity: 95 to 100 percent

- Highest freezing point: $30.7^{\circ} \mathrm{F}\left(-0.7^{\circ} \mathrm{C}\right)$

- Top- or package-ice $O K$

Precool radishes to remove field heat and preserve natural crispness. Most radishes are topped and packed in consumer-size plasticfilm packages which are shipped in waxed, corrugated fiberboard boxes. Some radishes are shipped with their tops on and to keep them fresh, these radishes must have top-ice or package-ice placed in the containers.

Topped radishes packed in consumer bags keep well in transit and storage for several weeks, provided the recommended temperature and humidity are maintained. Black spotting is a major market disease of radishes, but temperatures below $50^{\circ} \mathrm{F}\left(10^{\circ} \mathrm{C}\right)$ control it effectively.

Recommended loading methods:

- Waxed fiberboard boxes (consumer pack- 
ages)_-If shipping a straight load of radishes, hand-stack boxes in an airflow pattern (figure 10) to allow uniform circulation of refrigerated air throughout the load.

- Wirebound crates or fiberboard boxes (bunches with tops) _LLoad crates or boxes lengthwise on their bottoms. Keep rows aligned, evenly dividing the space between them for top-ice to fill (figure 16).

- Polyethylene bags (bulk radishes) -

Bagged radishes are usually shipped stacked on pallets. See figure 12 for pallet loading patterns. For top-iced loads, use the load pattern in figure 12a which leaves space between the pallet rows and the walls for top-ice to fill.

\section{Raspberries}

\section{Recommended transport conditions:}

- Desired transit temperature: $32^{\circ} \mathrm{F}\left(0^{\circ} \mathrm{C}\right)$

- Desired relative humidity: 90 to 95 percent

- Highest freezing point: black $-30.0^{\circ} \mathrm{F}\left(-1.1^{\circ} \mathrm{C}\right)$ red $-30.9^{\circ} \mathrm{F}\left(-0.6^{\circ} \mathrm{C}\right)$

Fresh raspberries soften and decay rapidly. Under the very best conditions their market life is 7 to 10 days. Transcontinental truck shipments of red raspberries from California are common. These shipments are usually palletized and in mixed loads with strawberries, which have similar packaging and transit requirements. Raspberries are subject to various types of mold, which can be controlled most effectively by rapidly precooling and holding the berries at the desired $32^{\circ} \mathrm{F}\left(0^{\circ} \mathrm{C}\right)$ temperature immediately after harvest. For additional protection against decay and ripening during transit, major shippers enclose the pallet loads of berries in air tight plastic bags and inject an atmosphere modified with 10 to 20 percent carbon dioxide $\left(\mathrm{CO}_{2}\right)$.

\section{Recommended loading method:}

- Corrugated fiberboard trays-Load trays lengthwise on bottoms. Trays of berries usually are palletized to minimize handling. Strap the trays securely to the pallets to minimize bouncing and rotating of the berries from highway shock and vibration, a major cause of physical damage to berries during transit. Center-load the pallets and brace away from the walls so that air can circulate between the walls and the product (figure 12b).

\section{Rhubarb}

\section{Recommended transport conditions:}

- Desired transit temperature: $32^{\circ} \mathrm{F}\left(0^{\circ} \mathrm{C}\right)$

- Desired relative humidity: 95 to 100 percent

- Highest freezing point, stalks: $30.3^{\circ} \mathrm{F}\left(-0.9^{\circ} \mathrm{C}\right)$

Keep fresh rhubarb at $32^{\circ} \mathrm{F}\left(0^{\circ} \mathrm{C}\right)$ and at a high humidity to prevent wilting and shriveling. Bunches or loose stalks of rhubarb are usually wrapped in polyethylene film liners before packing in shipping boxes to prevent moisture loss. Do not seal the liners, and ensure the boxes or crates are well vented to allow refrigerated air to remove respiration heat and prevent mold development.

\section{Recommended loading methods:}

- Fiberboard boxes-Load boxes lengthwise or crosswise on pallets. Load hand-stacked boxes lengthwise on their bottoms in an airflow pattern (figure 10). See figure 12 for pallet loading patterns.

\section{Romaine Lettuce}

\section{Recommended transport conditions:}

- Recommended transit temperature: $32^{\circ} \mathrm{F}\left(0^{\circ} \mathrm{C}\right)$

- Recommended relative humidity: 95 percent

- Highest freezing point: $31.7^{\circ} \mathrm{F}\left(-0.2^{\circ} \mathrm{C}\right)$

Romaine is a highly perishable, leafy vegetable requiring maximum refrigeration dur- 
ing transit. Vacuum-cool or hydrocool before shipment, depending on the shipper's facilities. Romaine is often shipped in mixed loads, because most orders are for less-thantruckload lots. It is packed both loose and in plastic bags in fiberboard boxes. Romaine is sensitive to ethylene gas, so do not ship with ethylene-producing products.

\section{Recommended loading methods:}

- Fiberboard boxes (waxed)—Load boxes lengthwise on their bottoms. Load handstacked boxes in an airflow pattern (figure 10). Center-load palletized boxes, or use an airflow pattern to keep the product away from the walls of the vehicle (figures 12a and $b$ ).

\section{Salad Mixes}

\section{Recommended transport conditions:}

- Recommended transit temperature: $33^{\circ} \mathrm{F}\left(0.6^{\circ} \mathrm{C}\right)$

- Recommended relative humidity: 90 to 95 percent

- Highest freezing point:

Varies by commodity components (refer to individual commodity)

Prepackaged salad mixes are one of the fastest growing segments of the produce industry. Salad mixes may contain a wide variety of vegetables, but the primary components are usually lettuce, cabbage, and other leafy greens. The mixes are usually vacuum-packaged in plastic film bags and shipped in fiberboard boxes. A number of shippers also inject a mixture of gases or modified atmosphere into the film package which is custom-formulated to extend the shelf life of the particular mix of vegetables in the salad. To obtain a maximum shelf life of 10 to 14 days for salad mixes, maintain the desired transit temperature. Also, do not puncture the film bags during handling, which may allow the introduction of ethylene gas and result in russeting and yellowing of the salad components.

\section{Recommended loading methods:}

- Fiberboard boxes-Load boxes lengthwise or crosswise on pallets. Secure the boxes to the pallets to prevent handling damage to the bags and salad leaves, and use an offwall loading pattern (figures $12 \mathrm{a}$ and $\mathrm{b}$ ). Load hand-stacked boxes in an airflow pattern (figure 10).

\section{Spinach}

\section{Recommended transport conditions:}

- Desired transit temperature: $32^{\circ} \mathrm{F}\left(0^{\circ} \mathrm{C}\right)$

- Desired relative humidity: 95 to 100 percent

- Highest freezing point: $31.5^{\circ} \mathrm{F}\left(-0.3^{\circ} \mathrm{C}\right)$

\section{- Top-ice and/or package-ice desired}

Fresh spinach is delicate and highly perishable. Handle carefully to prevent damage to the leaves which presents a potential point for disease entry. Precool fresh spinach immediately after harvest, hold near $32^{\circ} \mathrm{F}\left(0^{\circ} \mathrm{C}\right)$, and pack with ice to prevent wilting and preserve its shelf life of about 10 to 14 days. Spinach is sensitive to ethylene, so do not ship with ethylene-producing products.

\section{Recommended loading methods:}

- Wirebound crates or waxed fiberboard boxes-When top-iced, load hand-stacked crates or boxes lengthwise on their bottoms in straight rows. Divide space evenly between the rows for top-ice to fill (figure 16). Stack waxed fiberboard boxes directly on top of each other so melt-water can run down through the stack. If not top-iced, load crates or boxes in an airflow pattern (figures 10 and 11).

- Fiberboard boxes-Spinach is often packed in plastic film consumer packs, and then in fiberboard boxes. For hand-stacked boxes, load in an airflow pattern (figure 10). Stack palletized boxes of consumer packs in register, and secure with strapping to prevent bruising of the tender leaves. Figures $12 \mathrm{a}$ and $\mathrm{b}$ show the recommended pallet loading patterns. 


\section{Squash and Pumpkins}

\section{Recommended transport conditions:}

Winter squash (Hubbard and acorn) and pumpkins

- Desired transit temperature: $50^{\circ}$ to $55^{\circ} \mathrm{F}\left(10^{\circ}\right.$ to $\left.13^{\circ} \mathrm{C}\right)$

- Desired relative humidity: 50 to 70 percent

- Highest freezing point: $30.5^{\circ} \mathrm{F}\left(-0.8^{\circ} \mathrm{C}\right)$

Summer squash (yellow crookneck, straightneck, and zucchini)

- Desired transit temperature $41^{\circ}$ to $50^{\circ} \mathrm{F}\left(5^{\circ}\right.$ to $\left.10^{\circ} \mathrm{C}\right)$

- Desired relative humidity 95 percent

- Highest freezing point: $31.1^{\circ} \mathrm{F}\left(-0.5^{\circ} \mathrm{C}\right)$

After harvest, allow winter squash and pumpkins to cure at temperatures between $80^{\circ}$ and $85^{\circ} \mathrm{F}\left(27^{\circ}\right.$ to $29^{\circ} \mathrm{C}$ ) for 10 to 20 days to allow healing of mechanical cuts. Cured squash have a storage life of 2 to 6 months. However, they are subject to chilling injury, so do not keep or ship them at temperatures below $50^{\circ} \mathrm{F}\left(10^{\circ} \mathrm{C}\right)$ for any length of time. They also require low humidity.

Summer squash are harvested and shipped at an immature stage. They are more perishable than winter squash. Their storage life is shorter, and they require lower temperatures and higher humidity during transit. The skin of summer squash is very tender and easily wounded during handling. Summer squash is chilling-sensitive but can withstand $32^{\circ}$ to $40^{\circ} \mathrm{F}\left(0^{\circ}\right.$ to $\left.4^{\circ} \mathrm{C}\right)$ temperatures for up to 2 days with little danger of chilling injury.

\section{Recommended loading methods:}

- Wirebound crates - Load crates of summer squash lengthwise on their bottoms in an airflow pattern (figure 10). Crates of winter squash may be tightly stacked either lengthwise or crosswise on bottoms. Stack wirebound crates in vertical alignment and never allow them to cross over each other, because they are not designed to bear overhead weight on their sidewalls. When palletized, stack the crates in vertical alignment and strap securely to the pallet. Center-load the pallets away from the walls (figure 12b), unless the walls are ribbed to allow air circulation.

- Fiberboard boxes-Load fiberboard boxes of winter squash crosswise or lengthwise on their bottoms. Load hand-stacked boxes of summer squash in an airflow pattern (figure 10). Center-load palletized boxes (figure 12b).

- Bulk-bins-Pumpkins often are shipped in bulk bins. If the bins are double stacked, take care not to over fill the bins on the bottom layer, or pumpkins will be crushed.

\section{Strawberries}

\section{Recommended transport conditions:}

- Desired transit temperature: $32^{\circ} \mathrm{F}\left(0^{\circ} \mathrm{C}\right)$

- Desired relative humidity: 90 to 95 percent

- Highest freezing point: $30.6^{\circ} \mathrm{F}\left(-0.8^{\circ} \mathrm{C}\right)$

Strawberries are extremely perishable and rarely keep more than 10 days under ideal conditions. Temperatures near $32^{\circ} \mathrm{F}\left(0^{\circ} \mathrm{C}\right)$ are essential to control decay and ripening. Precool strawberries immediately after harvest to as close to $32^{\circ} \mathrm{F}\left(0^{\circ} \mathrm{C}\right)$ as possible.

Most California shippers palletize their strawberries. In some cases, they place a sealed plastic bag around each pallet load unit, filled with a modified atmosphere containing about 14 percent $\mathrm{CO}_{2}$ gas to assist in retarding decay and ripening.

Strawberries are highly susceptible to decay by fungal rots and molds. Ship only sound fruit, because decay fungi are easily spread throughout the shipping container. Handle strawberries very carefully, since they are easily bruised. Bruised berries are very susceptible to decay.

Recommended loading methods: 
- Open-top fiberboard tray boxes-Nearly all strawberries are shipped in tray boxes which are designed to interlock by wires or tabs when stacked in register. Load handstacked trays in rows lengthwise on their bottoms and stabilize every fourth layer with wood strips placed horizontally across the truck.

Secure palletized loads with strapping to prevent the trays of berries from bouncing. Highway shock and vibration is a major cause of intransit abrasion and bruising. Take extreme care to load and brace the pallets to prevent intransit shifting. Center-load the pallets off the walls to prevent heat conduction from the trailer walls to the fruit (figures 12a and 17).

\section{Sweet Potatoes}

\section{Recommended transport conditions:}

- Desired transit temperature: $55^{\circ}$ to $60^{\circ} \mathrm{F}\left(13^{\circ}\right.$ to $\left.16^{\circ} \mathrm{C}\right)$

- Desired relative humidity: 85 to 90 percent

- Highest freezing point: $29.7^{\circ} \mathrm{F}\left(-1.3^{\circ} \mathrm{C}\right)$

Sweet potatoes are harvested in late summer or early fall. Some are shipped immediately to market in the "green" state, noncured. The rest are cured and shipped from storage throughout the year. They are washed, sorted, and sometimes treated with a decay preventive before being shipped to market.

Also, many shippers wax sweet potatoes and dye them red.

Uncured sweet potatoes require careful handling to prevent skin breaks and decay. Cured sweet potatoes are easier to handle. Sweet potatoes are subject to chilling injury at temperatures below $50^{\circ} \mathrm{F}\left(10^{\circ} \mathrm{C}\right)$, even if only for a few hours, which may impair their appearance, taste and texture. Sprouting may occur at temperatures above $60^{\circ} \mathrm{F}$ $\left(16^{\circ} \mathrm{C}\right)$, and temperatures above $70^{\circ} \mathrm{F}\left(21^{\circ} \mathrm{C}\right)$ may cause decay.

Sweet potatoes are predominantly shipped in fiberboard boxes containing 50 pounds (23 $\mathrm{kg}$ ); however, some are packed in smaller fiberboard boxes, and some are packed in wirebound crates, or bags.

\section{Recommended loading methods:}

- Fiberboard boxes-Load boxes lengthwise on their bottoms. Load hand-stacked boxes in an airflow pattern (figure 10). See figure 12 for pallet loading patterns.

\section{Tangerines}

\section{Recommended transport conditions:}

- Desired transit temperature: $40^{\circ} \mathrm{F}\left(4^{\circ} \mathrm{C}\right)$

- Desired relative humidity 90 to 95 percent

- Highest freezing point: $30.1^{\circ} \mathrm{F}\left(-1.1^{\circ} \mathrm{C}\right)$

Tangerines are highly perishable. During marketing they are very susceptible to decay, particularly green- and blue-mold rots. Careful handling from tree to table helps to prevent bruising and skin breaks that provide ready entrance for decay organisms. Other citrus varieties, such as tangelos and honey tangerines (Murcott), are thinskinned and need careful handling. Most of these varieties can be shipped at near $32^{\circ} \mathrm{F}$ $\left(0^{\circ} \mathrm{C}\right)$ during domestic transit periods of several days. However, ship Temple oranges and Orlando tangelos at $40^{\circ} \mathrm{F}\left(4^{\circ} \mathrm{C}\right)$, because they are susceptible to chilling injury at lower temperatures. Precool tangerines before shipping.

\section{Recommended loading methods:}

- Fiberboard boxes-Load boxes lengthwise on their bottoms in an airflow pattern (figure $10)$. See figure 12 for pallet loading patterns.

- Wirebound crates - Load crates lengthwise on their bottoms in an airflow pattern (figures 10 and 11).

\section{Tomatoes (mature-green)}

\section{Recommended transport conditions:}

- Desired transit temperature: 
$55^{\circ}$ to $70^{\circ} \mathrm{F}\left(13^{\circ}\right.$ to $\left.21^{\circ} \mathrm{C}\right)$

- Desired relative humidity: 90 to 95 percent

- Highest freezing point: $31^{\circ} \mathrm{F}\left(-0.6^{\mathrm{O}}\right)$

Mature-green tomatoes are harvested in the green stage and are washed in chlorinated water, graded, and packed immediately after harvest. After packing, some tomatoes are placed in ethylene degreening rooms at $70^{\circ} \mathrm{F}\left(21^{\circ} \mathrm{C}\right)$ for about 48 to 72 hours to initiate ripening. Most go through this process at wholesale marketing facilities. After ethylene degreening, the best temperatures for transport and storage of tomatoes are between $55^{\circ}$ and $70^{\circ} \mathrm{F}\left(13^{\circ}\right.$ to $21^{\circ} \mathrm{C}$ ). At temperatures lower than $50^{\circ} \mathrm{F}$ $\left(10^{\circ} \mathrm{C}\right)$ mature-green tomatoes may incur chilling injury and be of poor internal quality. At temperatures above $70^{\circ} \mathrm{F}$ $\left(21^{\circ} \mathrm{C}\right)$, tomatoes may ripen too rapidly and decay extensively.

\section{Recommended loading methods:}

- Fiberboard boxes-Most tomatoes are shipped in partial telescope fiberboard boxes. Load hand-stacked boxes in an airflow pattern (figure 10). Most shippers palletize their shipments. See figure 12 for pallet loading patterns.

\section{Tomatoes (pink)}

\section{Recommended transport conditions:}

- Desired transit temperature: $46^{\circ}$ to $50^{\circ} \mathrm{F}\left(7^{\circ}\right.$ to $\left.10^{\circ} \mathrm{C}\right)$

- Desired relative humidity: 90 to 95 percent

- Highest freezing point: $31.1^{\circ} \mathrm{F}\left(-0.5^{\circ} \mathrm{C}\right)$

Tomatoes harvested soon after their color begins to redden are called pink, or "vineripened" tomatoes. Pink tomatoes are not as sensitive to chilling injury as mature green fruit. Handle pink tomatoes carefully to avoid mechanical injury. External and internal bruising may affect appearance, color, or flavor. Shipping temperatures for pink tomatoes will depend largely on the number of days in transit and the degree of ripeness which the receiver may desire. Many shippers precool their pink tomatoes to the transit temperature which will maintain the desired color level. Pink tomatoes are generally packed in fiberboard boxes with two or three layers per box. Some shippers pack their pink tomatoes in pulp or foam trays.

\section{Recommended loading methods:}

- Fiberboard boxes-Load hand-stacked boxes lengthwise on bottoms in an airflow pattern (figure 10). Most shippers palletize their tomato loads. See figure 12 for pallet loading patterns.

\section{Watermelons}

\section{Recommended transport conditions:}

- Recommended transit temperature: $50^{\circ}$ to $60^{\circ} \mathrm{F}\left(10^{\circ}\right.$ to $\left.16^{\circ} \mathrm{C}\right)$

- Recommended relative humidity: 90 percent

- Highest freezing point: $31.3^{\circ} \mathrm{F}\left(-0.4^{\circ} \mathrm{C}\right)$

Watermelons are generally shipped in bulk under ventilated conditions. In moderate weather, refrigeration normally is not required for transit periods of a few days. Improve flavor and intensify color by holding watermelons up to 7 days at room temperature. However, if the melons are to be in transit for longer than 1 week, they should be refrigerated in the $50^{\circ}$ to $60^{\circ} \mathrm{F}\left(10^{\circ}\right.$ to $\left.16^{\circ} \mathrm{C}\right)$ range. At temperatures between $32^{\circ}$ to $50^{\circ} \mathrm{F}$ $\left(0^{\circ}\right.$ to $\left.10^{\circ} \mathrm{C}\right)$, watermelons are subject to chilling injury which may include pitting, off-flavors, and color loss. Watermelons also are sensitive to ethylene, so do not ship with ethylene-producing products. Serious transit losses may result when watermelons are cracked and bruised by improper handling and loading. Bruising makes the melons more susceptible to decay. When loading bulk melons, place cushioning material on the trailer floor to protect them. Various types of cushioning materials are available, such as excelsior, polystyrene foam, straw, etc. Although straw is commonly used, it is not recommended in trailers with floor 
grooves because it blocks air circulation under the load and fills desired spaces between the melons.

\section{Recommended loading methods:}

- Bulk-The greater percentage of watermelons are shipped in bulk. Load both the longtype and round-type melons in rows parallel to the sidewalls of the trailer. Even-numbered layers will hold one less melon than odd numbered-layers. The number of layers in a particular load will depend on the weight of the trailer, highway weight limitations, and the quality of the watermelons.
- Fiberboard boxes-Fiberboard boxes may contain two to six watermelons. Load the boxes lengthwise on their bottoms, one box directly on top of another, and either 4 or 5 boxes wide, depending on size of the trailer and boxes. Divide slack space across the width of the trailer evenly between the rows, providing lengthwise air channels between each row. Fiberboard boxes of watermelons are frequently palletized. See figure 12 for pallet loading patterns.

- Bulk bins-Bulk bins of watermelons on pallets may weigh from 800 to 1200 pounds (363 to $554 \mathrm{~kg}$ ). Stack the bins two-high in 


\section{Canned Foods}
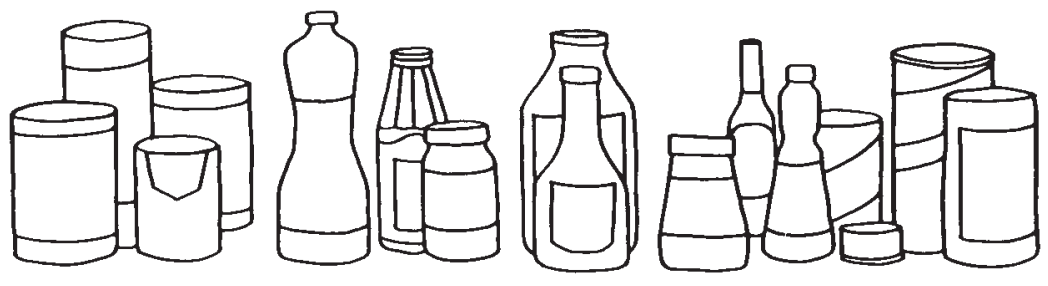

the trailer. To prevent crushing, put fewer melons in the lower bin. See figure 12 for pallet loading patterns.

Damage claims for canned goods cost carriers millions of dollars annually. There are two major causes of damage to canned foods during distribution-mechanical and temperature. Improper handling causes mechanical damage, dented or broken cans and bottles, and is responsible for the greatest percentage of claims. A smaller percentage of the claims results from improper temperature conditions, which cause rusting of the cans or freezing of the contents.

Damage is caused to canned goods in many ways, such as:

- poorly sealed cases;

- careless handling of cans during processing and warehousing;

- improper stacking on pallets;

- careless handling with mechanical-lift trucks;

- loose or slack loading in the vehicle;

- improper bracing, wrapping, or strapping; and

- failure to brace remainder of the load after a dropoff.

Poorly sealed cases may let cans or jars fall out during handling. Check cases of canned goods periodically during loading for indications of damage. Do not accept a heavily damaged load.

Currently, most canned goods are unitized for warehousing and shipment. Mishandling of pallets with mechanical-lift trucks and poor stacking of cases on the pallets are important sources of damage. Stack the cases so that they are flush with the edges of the pallet. If the cases overlap the edges of the pallet, lift trucks may push against the canned goods instead of the pallet during handling. If there is a space between the outside edges of the stack and the pallet edges, considerable slack space may be left between the pallets after they are loaded in the vehicle. This may allow the cases to shift during transit.

Another source of damage is loose pallet boards. A loose edge board will allow pressure to be exerted on the cases in the bottom layer, when the pallet is lifted with a fork lift truck. Keep pallets in good repair at all times.

A large percentage of the unit loads of canned goods are stretch- or shrink-wrapped with plastic film before shipment. This assures integrity of the pallet loads and reduces damage claims.

Tight loading is important, whether the shipment is unitized or hand-loaded. Any slack space that lets the cases shift or fall may result in damaged goods. Load the cases or pallet units snugly together, and brace the end of the last stack. In a split shipment, brace and block the end of the last stack before moving to the next dropoff. Use spacers or inflatable dunnage to fill out crosswise slack. All pallets or stacks should be the same height, unless precautions are taken by bracing or otherwise, to prevent the uneven top layer from shifting.

Truck drivers cannot control all damage that 
may occur before and during loading. However, they can reduce the chances of being blamed for damage beyond their control by being alert for damaged goods and not accepting them. They also can control the damage by closely supervising the loading of their vehicles. A good slogan for haulers of canned goods is, "The only right load is a tight load."

The most frequent type of temperature damage to canned foods is rusting of tin cans. Rusting is caused by condensation on cans removed from a low-temperature environment to one with a higher temperature. Condensation causes rust spots on the cans and wrinkling of the labels and may make the product unmarketable. Also, after a period of storage, the rust spots may pinhole the cans with leaks and allow the product to spoil. To prevent rust-causing condensation, do not unload canned foods in warm warehouse areas which have previously been subjected to low temperatures, until they have had time to warm up to $50^{\circ} \mathrm{F}\left(10^{\circ} \mathrm{C}\right)$ or above.

Freezing is not likely to damage the canned food product itself. However, freezing a canned product may endanger the container integrity or break a glass container. To protect canned food containers against freezing damage during transit through areas of intense cold, apply thermostatically controlled heat to keep the product from freezing. See table 4 for the freezing points of some canned foods.

Extended exposure of canned foods to $90^{\circ} \mathrm{F}$ $\left(32^{\circ} \mathrm{C}\right)$ or above temperatures is detrimental to product quality. In some cases, exposure 


\begin{tabular}{|c|c|c|}
\hline \multirow[b]{2}{*}{ Product } & \multicolumn{2}{|c|}{$\begin{array}{c}\text { Freezing } \\
\text { Point }\end{array}$} \\
\hline & ${ }^{\mathbf{O}} \mathbf{F}$ & ${ }^{\mathbf{0}} \mathrm{C}$ \\
\hline$\ldots \ldots \ldots \ldots \ldots \ldots \ldots$ & 27.6 & $(-2.4)$ \\
\hline$\ldots \ldots \ldots \ldots \ldots \ldots \ldots$ & 30.2 & $(-1.0)$ \\
\hline Beans, green stringless $\ldots \ldots \ldots \ldots \ldots \ldots \ldots$ & 30.3 & $(-0.9)$ \\
\hline$\ldots \ldots \ldots \ldots \ldots \ldots \ldots \ldots \ldots \ldots$ & 29.6 & $(-1.3)$ \\
\hline Beans, with pork $\ldots \ldots \ldots \ldots \ldots \ldots \ldots$ & 28.8 & $(-1.8)$ \\
\hline Beans, strained $\ldots \ldots \ldots \ldots \ldots \ldots \ldots \ldots$ & 30.6 & $(-0.8)$ \\
\hline Beans, wax, cans $\ldots \ldots \ldots \ldots \ldots \ldots \ldots \ldots \ldots \ldots \ldots \ldots \ldots \ldots \ldots \ldots$ & 30.3 & $(-0.9)$ \\
\hline Beans, wax, glass jars $\ldots \ldots \ldots \ldots \ldots \ldots \ldots$ & 30.2 & $(-1.0)$ \\
\hline 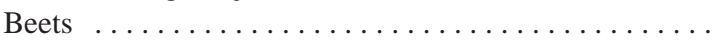 & 30.4 & $(-0.9)$ \\
\hline Carrots $\ldots \ldots \ldots \ldots \ldots \ldots \ldots \ldots \ldots$ & 30.3 & $(-0.9)$ \\
\hline 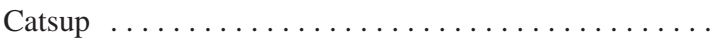 & 19.4 & $(-7.0)$ \\
\hline Chili sauce $\ldots \ldots \ldots \ldots \ldots \ldots \ldots \ldots \ldots$ & 23.7 & $(-4.6)$ \\
\hline Corn, creamed $\ldots \ldots \ldots \ldots \ldots \ldots \ldots \ldots$ & 29.6 & $(-1.3)$ \\
\hline Corn, in brine $\ldots \ldots \ldots \ldots \ldots \ldots \ldots \ldots \ldots$ & 29.4 & $(-1.4)$ \\
\hline Corn, vacuum-packed $\ldots \ldots \ldots \ldots \ldots \ldots \ldots$ & 29.7 & $(-1.3)$ \\
\hline Cranberry sauce $\ldots \ldots \ldots \ldots \ldots \ldots \ldots \ldots$ & 16.3 & $(-8.7)$ \\
\hline Grapefruit juice $\ldots \ldots \ldots \ldots \ldots \ldots \ldots \ldots \ldots \ldots \ldots \ldots \ldots \ldots$ & 30.2 & $(-1.0)$ \\
\hline Milk, evaporated $\ldots \ldots \ldots \ldots \ldots \ldots \ldots \ldots$ & 29.4 & $(-1.4)$ \\
\hline 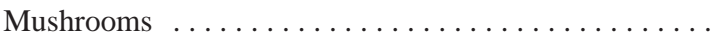 & 29.8 & $(-1.2)$ \\
\hline Peaches, heavy syrup $\ldots \ldots \ldots \ldots \ldots \ldots \ldots$ & 28.6 & $(-1.9)$ \\
\hline Peaches, light syrup $\ldots \ldots \ldots \ldots \ldots \ldots \ldots \ldots \ldots \ldots \ldots \ldots \ldots$ & 27.6 & $(-2.4)$ \\
\hline 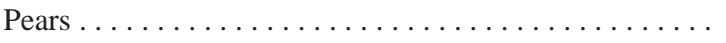 & 27.6 & $(-2.4)$ \\
\hline Peas, Alaska . . . . . . . . . . . . . . . . & 31.0 & $(-0.6)$ \\
\hline Peas, sweet $\ldots \ldots \ldots \ldots \ldots \ldots \ldots \ldots \ldots$ & 29.3 & $(-1.5)$ \\
\hline 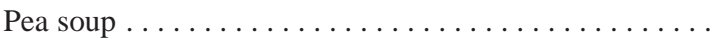 & 27.7 & $(-2.4)$ \\
\hline Potted meat $\ldots \ldots \ldots \ldots \ldots \ldots \ldots \ldots \ldots$ & 26.0 & $(-3.3)$ \\
\hline 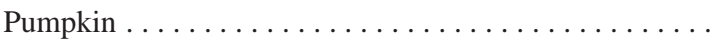 & 30.7 & $(-0.7)$ \\
\hline 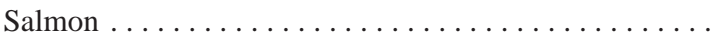 & 27.2 & $(-2.7)$ \\
\hline 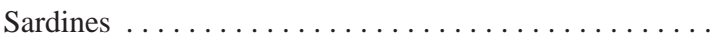 & 28.2 & $(-2.1)$ \\
\hline Spiced meat $\ldots \ldots \ldots \ldots \ldots \ldots \ldots \ldots \ldots$ & 22.2 & $(-5.4)$ \\
\hline 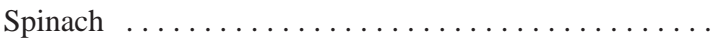 & 30.8 & $(-0.7)$ \\
\hline 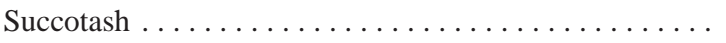 & 29.9 & $(-1.2)$ \\
\hline Sweet potatoes $\ldots \ldots \ldots \ldots \ldots \ldots \ldots \ldots \ldots \ldots$ & 29.2 & $(-1.6)$ \\
\hline 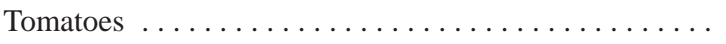 & 30.8 & $(-0.7)$ \\
\hline Tomato juice $\ldots \ldots \ldots \ldots \ldots \ldots \ldots \ldots$ & 29.8 & $(-1.2)$ \\
\hline Tomato soup $\ldots \ldots \ldots \ldots \ldots \ldots \ldots \ldots$ & 27.4 & $(-2.6)$ \\
\hline 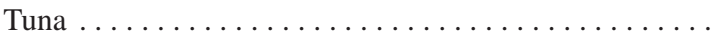 & 26.3 & $(-3.2)$ \\
\hline 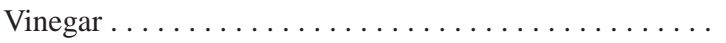 & 28.7 & $(-1.8)$ \\
\hline
\end{tabular}




\section{Dairy Products}

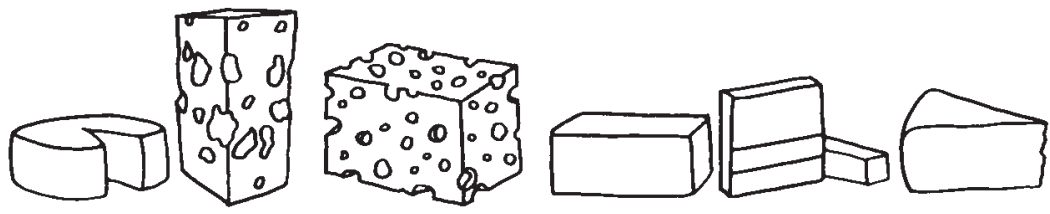

to these higher temperatures may result in total product loss through thermophylic spoilage.

\section{Butter and Margarine}

\section{Recommended transport conditions:}

- Desired transit temperature:

Butter (fresh), $39^{\circ} \mathrm{F}\left(4^{\circ} \mathrm{C}\right)$

Butter (frozen), $-10^{\circ} \mathrm{F}\left(-23^{\circ} \mathrm{C}\right)$

Margarine, $35^{\circ} \mathrm{F}\left(2^{\circ} \mathrm{C}\right)$

- Desired relative humidity:

Butter, 75 to 85 percent

Margarine, 60 to 70 percent

Butter and margarine usually are shipped from cold storage and are at the desired transit temperature when loaded. They are packed in fiberboard boxes that provide some insulation and allow the product to be exposed to room temperatures for short periods during loading and unloading without the risk of serious damage. However, during shipment the products must be refrigerated at the recommended temperatures to prevent softening and quality deterioration. Butter and margarine absorb odors very easily. Trucks or trailers previously used for hauling odorous products, such as fish, cabbage, or onions, should be well cleaned and aired before being loaded with butter or margarine. See section II "Cleaning and Sanitation" for hints on removing odors from trailers.

\section{Recommended loading methods:}

- Fiberboard boxes-Load boxes either crosswise or lengthwise on their bottoms on pallets or the truck floor. If the products are at the desired transit temperature when loaded, stack the boxes as tightly together as possible to retain that temperature.

In hot weather, take care to prevent heat conducted through the walls and floor from melting the product. To prevent this, provide space for refrigerated air to circulate around the perimeter of the load. Some vehicles are equipped with deep channel floors and ribbed walls for this purpose. If not, attach spacer strips vertically to the interior sidewalls to provide air space between the product and the walls. For hand-stacked loads place pallets on the floor with the stringers running lengthwise to allow air circulation under the load. Center-load pallets (figure 12b).

\section{Cheeses}

\section{Recommended transport conditions:}

- Desired transit temperature: $34^{\circ}$ to $40^{\circ} \mathrm{F}\left(1^{\circ}\right.$ to $\left.4^{\circ} \mathrm{C}\right)$

- Desired relative humidity: 65 to 70 percent

- Highest freezing point:

Variable by variety. Also, freezing may result in textural changes; see text.

Cheeses need to be protected from heat and cold. Most cheeses tend to "oil off" at $68^{\circ} \mathrm{F}$ $\left(20^{\circ} \mathrm{C}\right)$ and above. During oiling off, the fat leaks from the body, and the cheese quickly becomes rancid.

On the other hand, subjecting some types of cheeses to freezing temperatures will result in texture changes that may not be acceptable to consumers. As a general rule, cheese should not be held at temperatures below $30^{\circ} \mathrm{F}\left(-1^{\circ} \mathrm{C}\right)$ or above $50^{\circ} \mathrm{F}\left(10^{\circ} \mathrm{C}\right)$. 


\begin{tabular}{|c|c|c|}
\hline \multirow[t]{2}{*}{ Cheese } & \multicolumn{2}{|c|}{$\begin{array}{l}\text { Ideal Transit } \\
\text { Temperature }\end{array}$} \\
\hline & ${ }^{\mathrm{o}} \mathrm{F}$ & ${ }^{\circ} \mathrm{C}$ \\
\hline Brick $\ldots \ldots \ldots \ldots \ldots \ldots \ldots \ldots$ & 30 to 34 & -1.1 to 1.1 \\
\hline$\ldots \ldots \ldots \ldots \ldots \ldots \ldots$ & 30 to 34 & -1.1 to 1.1 \\
\hline Cheddar ..... & 30 to 34 & -1.1 to 1.1 \\
\hline Cottage $\ldots \ldots \ldots \ldots \ldots \ldots \ldots$ & 30 to 34 & -1.1 to 1.1 \\
\hline Cream $\ldots \ldots \ldots \ldots \ldots \ldots \ldots \ldots \ldots \ldots \ldots \ldots \ldots \ldots \ldots \ldots$ & 32 to 34 & 0.0 to 1.1 \\
\hline Limburger $\ldots \ldots \ldots \ldots \ldots \ldots \ldots$ & 30 to 34 & -1.1 to 1.1 \\
\hline Neufchatel .................. & 32 to 34 & 0.0 to 1.1 \\
\hline Process American $\ldots \ldots \ldots \ldots \ldots \ldots$ & 40 to 45 & 4.4 to 7.2 \\
\hline Process brick . . . . . . . . . . . & 40 to 45 & 4.4 to 7.2 \\
\hline Process Limburger $\ldots \ldots \ldots \ldots \ldots \ldots$ & 40 to 45 & 4.4 to 7.2 \\
\hline Process Swiss $\ldots \ldots \ldots \ldots \ldots \ldots \ldots$ & 40 to 45 & 4.4 to 7.2 \\
\hline Roquefort $\ldots \ldots \ldots \ldots \ldots \ldots \ldots \ldots$ & 30 to 34 & -1.1 to 1.1 \\
\hline Swiss $\ldots \ldots \ldots \ldots \ldots \ldots \ldots \ldots \ldots$ & 30 to 34 & -1.1 to 1.1 \\
\hline Cheese foods $\ldots \ldots \ldots \ldots \ldots \ldots \ldots$ & 40 to 45 & 4.4 to 7.2 \\
\hline
\end{tabular}

The recommended temperatures for transporting and holding some common types of cheeses are shown in table 5 .

\section{Recommended loading methods:}

- See previous entry, "Butter and Margarine."

\section{Ice Cream}

\section{Recommended transport conditions:}

- Desired transit temperature: $-20^{\circ}$ to $-15^{\circ} \mathrm{F}$ to $\left(-29^{\circ}\right.$ to $\left.-26^{\circ} \mathrm{C}\right)$

To maintain top quality, ice cream must be kept at the desired transit or holding temper- ature. It also is very important to keep the temperature of ice cream constant during loading and unloading. Fluctuating temperatures cause the ice crystals in ice cream to increase in size. Frequent temperature fluctuations will increase the crystal size to the point where the ice cream is no longer acceptable to the consumer.

Trucks used for hauling ice cream should be built specifically for that purpose, or meet the Refrigerated Transportation Foundation's (RTF) combined equipment DF (deep frozen or $-20^{\circ} \mathrm{F}$ ) rating. RTF-certified trailers will have the equipment rating posted at several locations on the exterior of the trailer and on the refrigeration unit (figure 8). 


\section{Fresh and Cured Meat and Fresh Seafood}

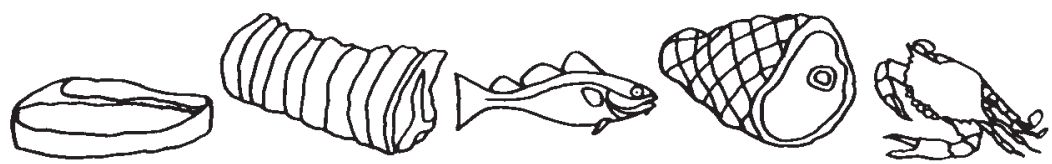

\section{Recommended loading methods:}

- See "Frozen Foods."

Meat products are highly perishable, and growth of microorganisms inherent on meat carcasses is a major cause of deterioration. Proper refrigeration is necessary to retard the growth of these microorganisms and preserve the fresh physical appearance of the meat products. Dehydration also affects the appearance and marketability of fresh meat. Table 6 gives the recommended temperatures and humidities for transporting some fresh meat, seafood, and processed meat products.

Fresh meats absorb odors readily, so do not load in vehicles retaining strong residual odors from other products. Do not ship meats in mixed loads with strong odor-producing products, such as fish, apples, or onions.

\section{Boxed Meats}

In the United States, nearly all meat animal carcasses are broken into wholesale or retail cuts, film packaged, and packed in corrugated fiberboard boxes before shipment. Most wholesale beef cuts are vacuum packaged in plastic film. If not vacuum-packed, cuts are usually individually wrapped before boxing or packed in a plastic bag liner inside the boxes. The packaging materials greatly reduce the chance of microbial contamination and dehydration of the meat during transport. However, the insulating effect of the boxes and packaging film make it imperative that the meat be at the desired transit temperature when packed and loaded. It will be difficult for the truck's refrigeration system to remove any heat remaining in the meat due to the packaging insulation.

\section{Recommended loading methods:}

- Fiberboard boxes-Since meat does not produce respiration heat, stack the boxes tightly together, if the meat is at the correct transit temperature when loaded. The same principle applies here as applies to frozen foods. Keep a blanket of cold air circulating around the load to absorb the heat penetrating the walls and floor of the trailer. If the trailer does not have ribbed walls, in hot weather load the boxes in a cross-wise offset pattern (figure $7 \mathrm{a}$ ) to reduce contact of the load with the walls. Use a trailer with a deep channel floor, or provide pallets or floor racks with 2 inches $(5 \mathrm{~cm})$ or more space for air circulation under the load. In trucks with overhead air delivery, leave 4 inches (10 $\mathrm{cm}$ ) of space between the load and the rear doors to assure adequate air circulation. Center-load palletized boxes (figure 12b).

\section{Carcass Meats}

Since carcass meats may not be protected by packaging, take extra precautions to protect the carcasses from additional contamination by unsanitary handling, dirt, and strong odors. The interior of the vehicle must be constructed of or coated with materials approved for contact with meat by the USDA's Food Safety and Inspection Service (FSIS). See section VI, "Regulatory Considerations for Truck Construction Materials, Cleaning Compounds, and Sanitary Food Transport."

Keep all interior surfaces of the truck in 
Table 6. Recommended Temperatures and Humidities for Protecting Selected Fresh, Cured, and Processed Meat and Seafood Products During Transit (from ASHRAE Refrigeration Handbook)

\begin{tabular}{|c|c|c|c|}
\hline \multirow[t]{2}{*}{ Commodity } & \multicolumn{2}{|c|}{ Temperature } & \multirow{2}{*}{$\begin{array}{c}\begin{array}{c}\text { Relative } \\
\text { Humidity }\end{array} \\
\text { Percent }\end{array}$} \\
\hline & ${ }^{o} \mathrm{~F}$ & ${ }^{\circ} \mathrm{C}$ & \\
\hline \multicolumn{4}{|l|}{ Fresh meats: } \\
\hline Beef & 32 to 34 & 0.0 to 1.1 & 88 to 92 \\
\hline$\ldots \ldots \ldots \ldots \ldots \ldots$ & 32 to 34 & 0.0 to 1.1 & 85 to 90 \\
\hline Pork $\ldots \ldots \ldots \ldots \ldots \ldots \ldots \ldots \ldots \ldots \ldots \ldots$ & 32 to 34 & 0.0 to 1.1 & 85 to 90 \\
\hline Poultry $\ldots \ldots \ldots \ldots \ldots \ldots \ldots$ & 28 to 32 & -2.2 to 0.0 & 85 to 90 \\
\hline Rabbits $\ldots \ldots \ldots \ldots \ldots \ldots$ & 32 to 34 & 0.0 to 1.1 & 90 to 95 \\
\hline Veal $\ldots \ldots \ldots \ldots \ldots \ldots \ldots \ldots \ldots$ & 32 to 34 & 0.0 to 1.1 & 90 \\
\hline \multicolumn{4}{|l|}{ Cured and processed meats: } \\
\hline \multicolumn{4}{|l|}{ Bacon: } \\
\hline Cured, farm style $\ldots \ldots \ldots \ldots \ldots \ldots$ & 61 to 64 & 16.0 to 18.0 & 85 \\
\hline Cured, packer style ... & 34 to 39 & 1.0 to 4.0 & 85 \\
\hline Dried beef (chipped) $\ldots \ldots \ldots \ldots \ldots \ldots$ & 50 to 59 & 10.0 to 15.0 & 15 \\
\hline Frankfurters $\ldots \ldots \ldots \ldots \ldots \ldots$ & 32 & 0.0 & 85 \\
\hline \multicolumn{4}{|l|}{ Hams: } \\
\hline Light cure $\ldots \ldots \ldots \ldots \ldots \ldots \ldots$ & 37 to 41 & 3.0 to 5.0 & 80 to 85 \\
\hline Country cure $\ldots \ldots \ldots \ldots \ldots \ldots$ & 50 to 59 & 10.0 to 15.0 & 65 to 70 \\
\hline \multicolumn{4}{|l|}{ Pork Sausages (links or bulk } \\
\hline country and Polish) $\ldots \ldots \ldots \ldots \ldots$ & 32 & 0.0 & 85 \\
\hline \multicolumn{4}{|l|}{ Fresh fish: } \\
\hline Haddock, Cod, Perch & 31 to 34 & -0.6 to 1.1 & 95 to 100 \\
\hline Hake, Whiting . . . . . . . . . & 32 to 34 & 0.0 to 1.1 & 95 to 100 \\
\hline Halibut $\ldots \ldots \ldots \ldots \ldots \ldots$ & 31 to 34 & -0.6 to 1.1 & 95 to 100 \\
\hline \multicolumn{4}{|l|}{ Herring: } \\
\hline kippered & 32 to 36 & 0.0 to 2.2 & 80 to 90 \\
\hline smoked ... & 32 to 36 & 0.0 to 2.2 & 80 to 90 \\
\hline Mackerel $\ldots \ldots \ldots \ldots \ldots \ldots$ & 32 to 34 & 0.0 to 1.1 & 95 to 100 \\
\hline Menhaden $\ldots \ldots \ldots \ldots \ldots \ldots \ldots$ & 34 to 41 & 1.1 to 5.0 & 95 to 100 \\
\hline Salmon $\ldots \ldots \ldots \ldots \ldots \ldots$ & 31 to 34 & -0.6 to 1.1 & 95 to 100 \\
\hline Tuna $\ldots \ldots \ldots \ldots \ldots \ldots \ldots \ldots$ & 32 to 36 & 0.0 to 2.2 & 95 to 100 \\
\hline \multicolumn{4}{|l|}{ Shellfish: } \\
\hline Scallop meat & 32 to 34 & 0.0 to 1.1 & 95 to 100 \\
\hline Shrimp $\ldots \ldots \ldots \ldots \ldots \ldots \ldots$ & 31 to 34 & -0.6 to 1.1 & 95 to 100 \\
\hline Lobster (American) . . . . . . . . . & 41 to 50 & 5.0 to 10.0 & In sea water \\
\hline Oyster, clams & & & \\
\hline (meat and liquid) $\ldots \ldots$ & 32 to 36 & 0.0 to 2.2 & 100 \\
\hline Oyster in shell $\ldots \ldots \ldots \ldots \ldots \ldots \ldots$ & 41 to 50 & 5.0 to 10.0 & 95 to 100 \\
\hline
\end{tabular}


(a)

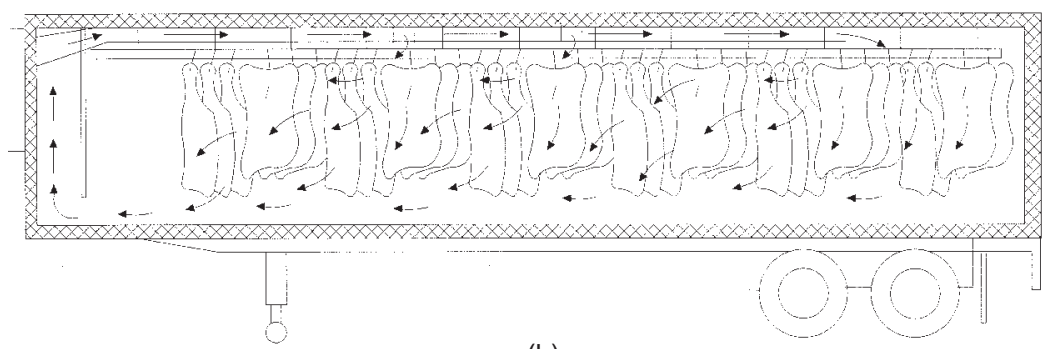

(b)
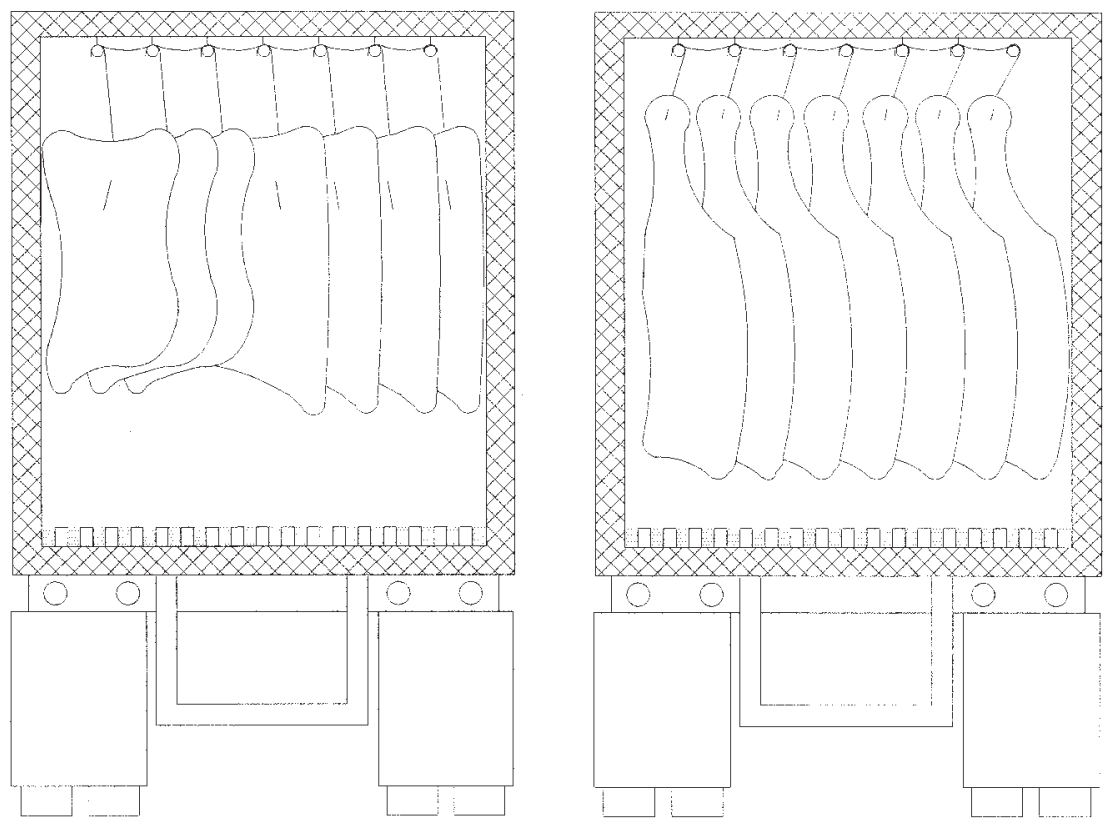

Figure 19.

Side (a) and end (b)

views of a mixed load of

hanging forequarters

and hindquarters of

beef.

good repair. Broken places in the wall and floor harbor dirt and are difficult to keep clean. Replace faulty or missing door gaskets and missing floor-drain caps to prevent dirt and dust from being sucked in the vehicle as it moves over the highway. Keep meat hooks and rails free of corrosion or rust that could work loose and fall on the carcasses.

Before loading, clean and inspect trucks, pallets, and meat hooks used for hauling carcasses. The wash water should be at least $180^{\circ} \mathrm{F}\left(82^{\circ} \mathrm{C}\right)$ to reduce the number of microorganisms present and to dissolve fat particles adhering to the interior surfaces. 
Any sanitizing agents must be approved for cleaning meat equipment by the USDA's FSIS.

In warm weather, precool trucks hauling meat carcasses before loading to prevent moisture from condensing on cold carcasses as they are loaded from refrigerated storage. Condensation creates conditions favorable for the growth of slime-forming microorganisms on the meat. Moisture also will condense on cold carcasses when doors are opened for delivery stops in warm weather. If at all possible, all loading and unloading should be in refrigerated areas.

\section{Recommended loading methods:}

There are many methods for loading carcass meats in trucks. Usually quarters of beef are hung by metal hooks on overhead rails. The forequarters are hung with long hooks inserted through the inside of the rib cavity, usually between the 4th and 5th ribs about 11 inches from the backbone, so the quarters will balance and hang straight. Hindquarters are hung with short hooks, the hook being inserted through the opening in the gambrel cord of the shank. Figure 19 shows a load of hanging beef.

Sometimes, both frozen and fresh meat carcasses are loaded stacked like cordwood on the floor of the truck, or on pallets which are in turn loaded on the truck. In these cases, place clean wrapping paper or plastic film approved by the FSIS between the truck floor or pallet base and the meat, and also 


\section{Frozen Foods}

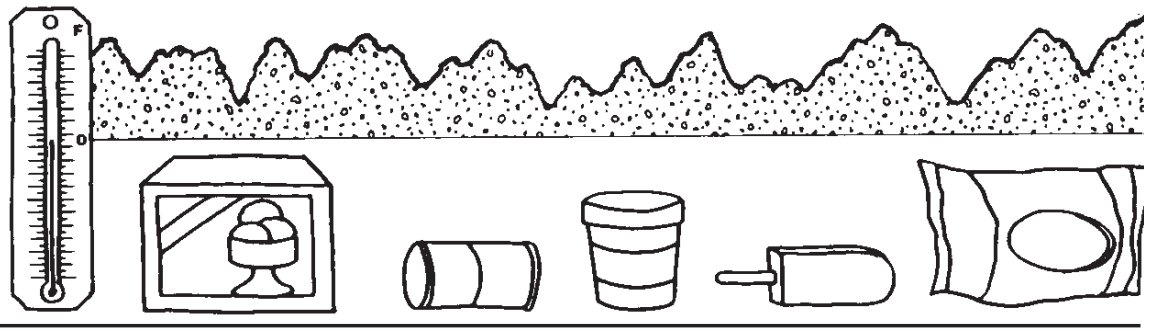

between the meat and the truck walls.

Frozen foods should be kept at $0^{\circ} \mathrm{F}\left(-18^{\circ} \mathrm{C}\right)$ or lower from the time they are first frozen until readied for consumption, according to the code of "Frozen Food Handling and Merchandising" available from the Frozen Food Roundtable. The "Roundtable" represents the major trade associations of the frozen food industry.

Fluctuating temperatures during distribution degrade the market quality of frozen foods. Recooling frozen foods to the thermostat set point after even a slight temperature rise causes moisture to migrate from the product to the colder surfaces of the packaging materials. This results in product dehydration and undesirable frost buildup inside the packages. Product quality losses will increase with the amount of temperature rise and frequency of recooling.

Frozen foods thaw between $15^{\circ} \mathrm{F}$ and $32^{\circ} \mathrm{F}$ $\left(-9^{\circ}\right.$ and $\left.0^{\circ} \mathrm{C}\right)$. Although the changes are not easily recognized, even at temperatures as low as $0^{\circ} \mathrm{F}\left(-18^{\circ} \mathrm{C}\right)$, frozen foods may deteriorate from fat oxidation and enzymatic changes. Certain microorganisms also may develop at temperatures around $20^{\circ} \mathrm{F}\left(-7^{\circ} \mathrm{C}\right)$ and above, adding to deterioration and contamination of the food. The higher the temperature, the greater the rate of deterioration.

Ensure that trucks transporting frozen food are:

- clean and free from dirt, debris, odors, or any substance that may contaminate the food;
- constructed, insulated, and equipped with adequate refrigeration capacity and air delivery system to continuously maintain a product temperature of $0^{\circ} \mathrm{F}\left(-18^{\circ} \mathrm{C}\right)$ or colder. (Trailers certified by the Refrigerated Transportation Foundation (RTF) will have a combined equipment rating of " $F$ " for frozen foods on the certification plates posted at various locations on the vehicle (see figure 8); and

- precooled by setting the thermostat at $0^{\circ} \mathrm{F}$ $\left(-18^{\circ} \mathrm{C}\right)$ and letting the refrigeration unit operate for at least one-half hour before loading, or until a temperature gradient is established across the insulation. Be sure to schedule adequate time for precooling in warm weather.

Load boxes of frozen foods in a solid block, avoiding contact with the walls. Ensure that air refrigerated at or below $0^{\circ} \mathrm{F}\left(-18^{\circ} \mathrm{C}\right)$ circulates around all sides of the load to prevent the transfer of heat through the trailer to the frozen product (figure 4). Floor channels, floor racks, or pallets 2-1/4 inches (6 $\mathrm{cm}$ ) or more deep will facilitate air circulation under the load.

Provide at least 4 inches $(10 \mathrm{~cm})$ of space between the load and the rear doors to let air flow freely around the rear of the load. For vehicles without ribbed walls, attach vertical stripping ( 1 or more inches thick) on the sidewalls to facilitate air circulation between the walls and load. Leave at least 10 inches $(25 \mathrm{~cm})$ of space between the ceiling and the top of the load for unobstructed airflow over the load.

A great deal of frozen food is shipped on pallets or slipsheets. Center-load pallets (figure 12b), and block or brace the load to keep 
the product from toppling against the walls.

If supplemental or emergency refrigeration is needed for a frozen food shipment, place solid carbon dioxide $\left(\mathrm{CO}_{2}\right)$ in the form of dry ice or snow on top of the load. Keep the fans running at low speed to uniformly dis- tribute cool air around the load.

WARNING: The gas $\mathrm{CO}_{2}$ may cause asphyxiation. Vent the vehicle properly 


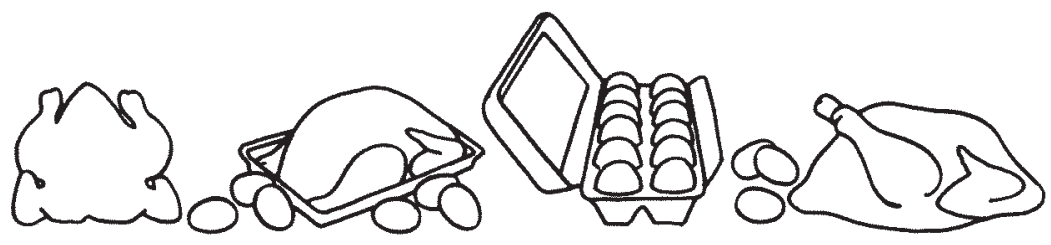

before entering.

\section{Poultry (fresh and hard-chilled)}

\section{Recommended transport conditions:}

- Desired transit temperatures:

Fresh, $26^{\circ}$ to $34^{\circ} \mathrm{F}\left(-3^{\circ}\right.$ to $\left.1^{\circ} \mathrm{C}\right)$

Hard-chilled, $0^{\circ} \mathrm{F}$ to $26^{\circ} \mathrm{F}\left(-18^{\circ}\right.$ to $\left.-3^{\circ} \mathrm{C}\right)$

- Desired relative humidity:

90 to 95 percent

- Average freezing point:

$27^{\circ} \mathrm{F}\left(-3^{\circ} \mathrm{C}\right)$

Fresh poultry is shipped by two methods, fresh and hard-chilled. After the birds are dressed, they are chilled to $40^{\circ} \mathrm{F}\left(4^{\circ} \mathrm{C}\right)$ or lower. At this point they may be packed in bins, boxes, or crates, with or without ice, and shipped for further processing or for immediate retail. Fresh poultry has a relatively short shelf life of a week or so at most.

Hard-chilled poultry has a shelf life of several weeks if it is cooled to below $26^{\circ} \mathrm{F}$ $\left(-3^{\circ} \mathrm{C}\right)$ soon after slaughter. The low temperature assures cell contraction and reduces tissue weepage. Most hard-chilled poultry is broken into retail cuts and packaged in foam trays overwrapped with vapor-proof plastic film. If the poultry is in good initial condition, additional shelf life may be obtained by vacuum packaging and gas flushing.

\section{Recommended loading methods:}

- Pallets-Most poultry is packed in fiberboard boxes and palletized for shipment. Ensure that the poultry is at the desired transit temperature when loaded. Secure the boxes to the pallets with strapping or stretch pling. Center-load the pallets off the walls (figure 12b).

\section{Shell Eggs}

\section{Recommended transport conditions:}

- Desired transit temperature: $40^{\circ} \mathrm{F}$ to $45^{\circ} \mathrm{F}\left(4^{\circ}\right.$ to $\left.7^{\circ} \mathrm{C}\right)$

- Desired relative humidity: 80 to 85 percent

- Average freezing point: $28.0^{\circ} \mathrm{F}\left(-2^{\circ} \mathrm{C}\right)$

Shell eggs are fragile and highly perishable. Even though it is not outwardly visible, egg quality deteriorates rapidly under poor environmental conditions.

Thoroughly clean and precool the truck or trailer to at least $45^{\circ} \mathrm{F}\left(7^{\circ} \mathrm{C}\right)$ before eggs are loaded. Since eggs absorb odors, ensure that the vehicle is free of residual odors. Do not ship eggs in mixed loads, especially not with citrus fruits, onions, or potatoes.

Because of their perishability and the insulating effect of the fiberboard boxes and cartons in which they are shipped, precool eggs to their desired transit temperature before they are loaded. Also, because the boxes are stacked tightly and may be secured on pallets with stretch film or strapping, there is little or no cooling air circulating through the load. Pending Federal legislation will require that eggs destined for consumer markets be precooled to at least $45^{\circ} \mathrm{F}\left(7^{\circ} \mathrm{C}\right)$ prior to loading and kept at or below this temperature during transit. 


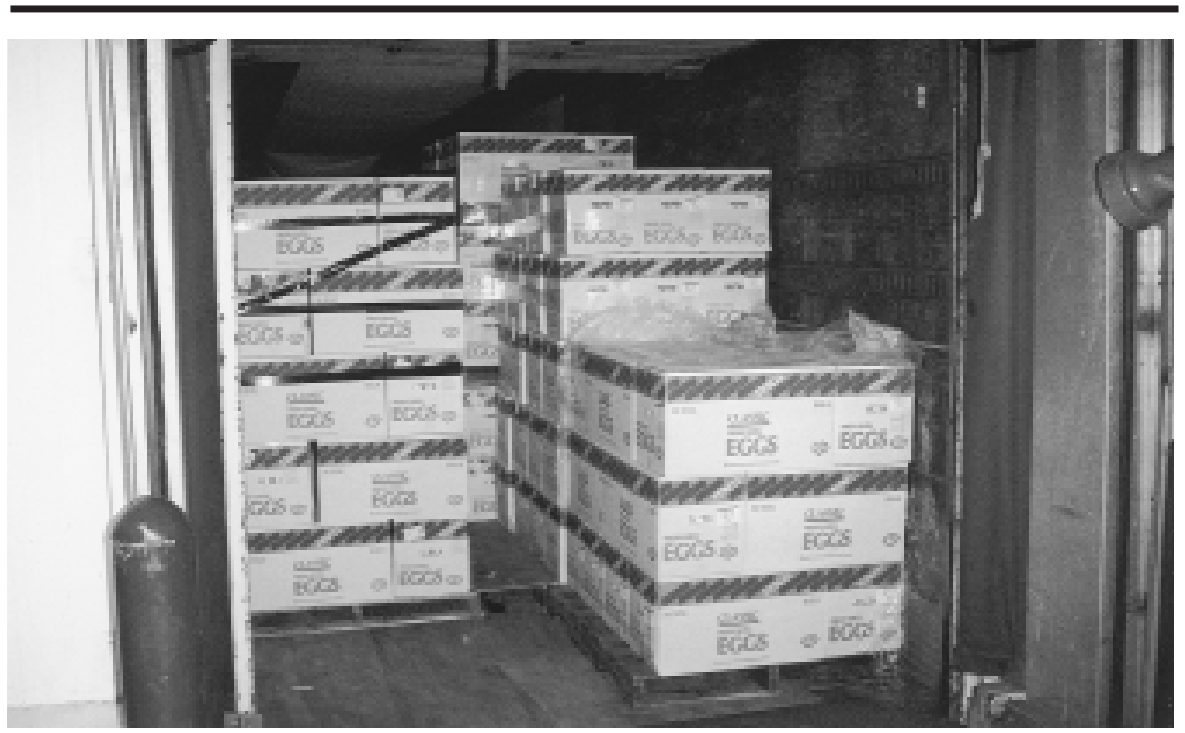

\section{Figure 20. \\ A palletized load of eggs. Note the stretch film around the pallet loads at the rear door area where road shock is greatest.}

\section{Recommended loading methods:}

-30- and 15-dozen fiberboard boxes-Nearly all eggs shipped in these boxes are palletized, 6 or 12 boxes per layer, on 48- $\mathrm{x} 40$ inch pallets. However, to maximize use of space in the trailer, hand-stack one row of boxes between the pallet rows in the middle of the trailer as in figure 20. Stack two rows of boxes between the pallet rows in some 102-inch $(2.6 \mathrm{~m})$ wide trailers.

Because eggs are so fragile, loading and bracing to prevent cargo movement is essential. To prevent forward shifting, load the first pallets snugly against the bulkhead, leaving no lengthwise slack between the pallets until the end of the load. If the pallet load heights are uneven, use loadlock bars across the truck at the top layer to prevent forward or rearward shifting. Or, in some cases, tape the top one or two layers of the pallet loads horizontally to prevent shifting.

Road shock and vibration are pronounced at the rear of the truck. Therefore, take extra care to secure the load in this area. This may be accomplished by shrink-wrapping the pallet loads at the rear doors (figure 20) and by using load-lock bars across the top of the load.

- Plastic crates-One-dozen cartons of eggs are shipped in plastic crates holding 15 or 30 cartons. The cartons are retailed directly from the crates. The crates fold or nest for easy return to the egg packing plant.

- Roll-on/off carts-These carts hold 3601 1dozen cartons of eggs. They are positioned on the truck so that the cartons will not slide or shift off the carts. The carts are braced or secured with load lock bars. The carts are 



\section{Appendix I}

rolled off the truck and onto the retail floor where the eggs are sold off the cart. Empty carts fold for less space on the return haul.

\section{Estimating Mobile Refrigeration Requirements}

Estimate the number of Btu's of heatload when there is any question as to whether the truck's refrigeration system has adequate capacity. This is particularly important in hot weather, if the pulp temperature of the product at loading is considerably above the desired transit temperature. Shippers who often receive claims of loss from decay should make calculations to determine if the refrigeration capacity is adequate for each load.

Consider the following three factors in estimating the heatload or amount of refrigeration needed to obtain and maintain the proper temperature during transit:

- Field or sensible heat $\left(\mathrm{H}_{\mathrm{f}}\right)$ left in the commodity and package

- Heat of respiration $\left(\mathrm{H}_{\mathrm{r}}\right)$

- Amount of heat leakage $\left(\mathrm{H}_{1}\right)$ through the walls of the trailer

Add these three factors to get the total number of Btu's that must be absorbed by the refrigeration system.

Field heat $\left(\mathrm{H}_{\mathrm{f}}\right)$ is the amount of heat that has to be removed from the product and the containers before the desired transit temperature is reached. In practice, most products have not been precooled to the desired transit temperature. This extra refrigeration requirement must be allowed for. To calculate field heat load, use the specific heat (Sp.ht.) of the product (table I-1) and container, the weight (Wt.) of the product and container, and the temperature differential (TD) as shown in the following formula:

$\mathrm{H}_{\mathrm{f}}=$ SP.ht. $\mathrm{x}$ Wt. $\mathrm{x}$ TD $=\mathrm{Btu}$

Determine heat of respiration $\left(\mathrm{H}_{\mathrm{r}}\right)$ by using the information in table I-2, which gives the amount of heat generated by one ton of a product in 24 hours at different temperatures. To calculate the respiration heat, the following formula can be used:

$\mathrm{H}_{\mathrm{r}}=$ Respiration rate (at average transit temperature) $\mathrm{x}$ time (no. of days) $\mathrm{x}$ Wt. (tons) $=\mathrm{Btu}$

Heat leakage $\left(\mathrm{H}_{1}\right)$ through the trailer body is estimated by determining:

- the coefficient of heat transfer (Ua factor) of the trailer body;

- the temperature differential between the thermostat setting and the average expected outside temperature; and

- the number of hours the product will be in the vehicle.

The Ua factor for a particular trailer body depends on many variables - type and thickness of insulation, air leakage, differential between the outside and inside air temperatures, and others. Therefore, for the purpose of estimating heat leakage it is impractical to give the details of all calculations needed to determine the Ua factor. However, the Ua factor based on a standard method of rating can be supplied by the manufacturers of some trailers. If the Ua factor is not readily available, use the following for general estimation of heatload:

- A factor $\mathrm{Ua}=140 \mathrm{Btu} /{ }^{\circ} \mathrm{F} / \mathrm{hr}$. may be used for a modern 48 -foot trailer with 2-1/2 inches of plastic foam sidewall insulation.

- If the trailer has been in service over 3 years, then a factor of $180 \mathrm{Btu} / \mathrm{oF} / \mathrm{hr}$. should be used to account for aging of deterioration of the insulation and door 


\section{Table I-1.- Specific Heat Above and Below Freezing of Certain Perishable Products. (adapted with permission from ASHRAE Handbook- Refrigeration)}

\section{Fruits and vegetables}

\section{Fruits and} vegetables
Btu/lb/0 $\mathbf{F}$.

Above Below

\begin{tabular}{|c|c|c|c|c|c|}
\hline Apples & 0.87 & 0.45 & Limes & .89 & .46 \\
\hline Apricots $\ldots \ldots \ldots \ldots$ & .88 & .46 & Mangoes ............ & .85 & .44 \\
\hline Artichokes (globe) ..... & .87 & .45 & Mushrooms & 0.93 & 0.47 \\
\hline Asparagus $\ldots \ldots \ldots \ldots$ & .94 & .48 & Nectarines . . & .86 & .44 \\
\hline Avocados $\ldots \ldots \ldots \ldots$ & .72 & .40 & Okra ........ & .92 & .46 \\
\hline Bananas ............ & .80 & .42 & Onions (dry) . . . . . . . & .90 & .46 \\
\hline Beans: & & & Oranges . & .90 & .46 \\
\hline Green snap & .91 & .47 & Parsley .... & .88 & .45 \\
\hline $\operatorname{Lima} \ldots \ldots \ldots \ldots$ & .73 & .40 & Parsnips $\ldots \ldots \ldots \ldots$ & .84 & .44 \\
\hline Beets (roots) . . . . . . . & .90 & .46 & Peaches $\ldots \ldots \ldots \ldots$. & .91 & .46 \\
\hline Blackberries . . . . . . . . & .88 & .46 & Pears . . . . . . . . . & .86 & .45 \\
\hline Blueberries . . . . . . . . & .86 & .45 & Peas (green) $\ldots \ldots \ldots \ldots$ & .79 & .42 \\
\hline Broccoli ........... & .92 & .47 & Peppers (sweet) . . . . . & .94 & .47 \\
\hline Brussels sprouts . . . . . . & .88 & .46 & Pineapples . . . . . . . & .88 & .45 \\
\hline$\ldots \ldots \ldots \ldots$ & .94 & .47 & Plums and fresh & & \\
\hline Cantaloupes $\ldots \ldots \ldots$. & .93 & .48 & Prunes $\ldots . .$. & .88 & .45 \\
\hline Carrots $\ldots \ldots \ldots \ldots \ldots$ & .90 & .46 & Potatoes: & & \\
\hline Casaba and & & & Early-crop . & .85 & .44 \\
\hline Crenshaw & & & Late-crop $\ldots \ldots \ldots \ldots$ & .82 & .43 \\
\hline melons & .94 & .48 & Sweet (see Sweet potatoes) & & \\
\hline Cauliflower & .93 & .47 & Prunes (see Plums) & & \\
\hline Celery ............. & .95 & .48 & Pumpkins ... & .92 & .47 \\
\hline Cherries (sweet) . . . . . & .84 & .44 & Radishes ........... & .95 & .48 \\
\hline Corn (sweet) $\ldots \ldots \ldots$ & .79 & .42 & Raspberries: & & \\
\hline Cranberries . . . . . . . & .90 & .46 & Black . & .84 & .44 \\
\hline Cucumbers $\ldots \ldots \ldots \ldots$ & .97 & .49 & Red & .87 & .45 \\
\hline$\ldots \ldots \ldots \ldots$ & .94 & .48 & Rhubarb & .95 & .48 \\
\hline Endive and Escarole .... & .94 & .48 & Romaine & & \\
\hline Figs (fresh) . . . . . . . & .82 & .43 & (see Lettuce) & & \\
\hline Garlic (dry) $\ldots \ldots \ldots$ & .69 & .40 & Spinach .. & .94 & .48 \\
\hline Gooseberries $\ldots \ldots \ldots$. & .90 & .46 & Squash: & & \\
\hline Grapefruit ......... & .90 & .46 & Summer & .95 & .48 \\
\hline Grapes $\ldots \ldots \ldots \ldots$ & .86 & .45 & Winter . & .88 & .45 \\
\hline Honeydew melons ...... & .94 & .48 & Strawberries ..... & .92 & .47 \\
\hline Kale $\ldots \ldots \ldots \ldots \ldots$ & .89 & .46 & Sweet potatoes . . . . . . & .76 & .41 \\
\hline Leeks . . . . . . . . & .88 & .46 & Tangerines $\ldots \ldots \ldots \ldots$ & .90 & .46 \\
\hline Lemons $\ldots \ldots \ldots \ldots$ & .91 & .46 & Tomatoes (ripe) . . . . . & .95 & .48 \\
\hline Lettuce (head) ........ & .96 & .48 & Watermelons ........ & .97 & .48 \\
\hline
\end{tabular}


Table I-1.-Specific Heat Above and Below Freezing of Certain Perishable Products - Continued

\begin{tabular}{|c|c|c|c|c|c|}
\hline \multirow[t]{2}{*}{$\begin{array}{l}\text { Dairy, meat and } \\
\text { poultry products }\end{array}$} & \multicolumn{2}{|c|}{ Btu/lb $/{ }^{0} \mathbf{F}$. } & \multirow[t]{2}{*}{$\begin{array}{l}\text { Dairy, meat and } \\
\text { poultry products }\end{array}$} & \multicolumn{2}{|c|}{ Btu $/ \mathrm{lb} /{ }^{\circ} \mathbf{F}$. } \\
\hline & Above & Below & & Above & Below \\
\hline$\ldots \ldots \ldots \ldots$ & .38 & .26 & Lamb (fresh) & .72 & .40 \\
\hline Beef (fresh) . . . . . . . & .77 & .41 & Milk ........ & .93 & .46 \\
\hline Butter . . . . . . . . & .36 & .25 & Oleomargarine & .32 & .25 \\
\hline Cheese $\ldots \ldots \ldots \ldots \ldots$ & .52 & .31 & Pork (fresh) . . & .53 & .31 \\
\hline Eggs (shell) & .73 & .40 & Poultry (fresh) & .80 & .42 \\
\hline Egg solids (whole). & .22 & .21 & Smoked sausage . & .62 & .35 \\
\hline Egg yolk solids $\ldots \ldots \ldots$ & .23 & .21 & Veal (fresh) . . & .74 & .40 \\
\hline Ice cream $\ldots \ldots \ldots \ldots$ & .70 & .39 & & & \\
\hline \multicolumn{6}{|l|}{ Hams: } \\
\hline Cured $\ldots \ldots \ldots \ldots$ & .67 & .37 & & & \\
\hline Fresh $\ldots \ldots \ldots \ldots \ldots$ & .53 & .31 & & & \\
\hline
\end{tabular}

seals.

$\mathrm{H}_{1}=\mathrm{Ua} \times \mathrm{TD} \times$ time (hours) $=\mathrm{Btu}$ 


\begin{tabular}{|c|c|c|c|c|c|}
\hline \multirow[t]{2}{*}{ Commodity } & \multicolumn{5}{|c|}{ Btu per ton per 24 hours } \\
\hline & $32^{\circ} \mathrm{F}$ & $40^{\circ} \mathrm{F}$ & $60^{\circ} \mathrm{F}$ & $7^{\circ} \mathrm{F}$ & $80^{\circ} \mathrm{F}$ \\
\hline Apples . & 700 & 1,350 & 4,900 & 5,700 & - \\
\hline Apricots $\ldots \ldots \ldots$. & - & 5,050 & 11,700 & 20,350 & - \\
\hline Artichokes $\ldots \ldots \ldots$ & 7,700 & 10,450 & 26,400 & 40,700 & 50,050 \\
\hline Asparagus . . . . . . . . . . & 9,700 & 18,050 & 38,500 & 48,750 & 93,250 \\
\hline Avocados $\ldots \ldots \ldots$ & - & 5,500 & 24,050 & 46,250 & 60,050 \\
\hline Bananas (green) ..... & - & - & 4,850 & 7,400 & - \\
\hline \multicolumn{6}{|l|}{ Beans: } \\
\hline Green snap & 7,250 & 10,300 & 38,100 & 49,200 & - \\
\hline Lima (in pod) ..... & 4,450 & 6,100 & 24,700 & 34,300 & - \\
\hline$\ldots \ldots \ldots$ & 2,700 & 4,100 & 7,200 & - & - \\
\hline Blackberries ........ & 4,100 & 7,950 & - & 38,350 & - \\
\hline Blueberries .......... & 1,400 & 2,350 & 10,550 & 15,300 & 22,250 \\
\hline Broccoli $\ldots . . . \ldots \ldots$ & 4,400 & 21,400 & 56,500 & 68,100 & 158,400 \\
\hline Brussels sprouts ..... & 4,400 & 7,700 & 22,000 & 28,350 & - \\
\hline Cabbage $\ldots . . . . .$. & 1,200 & 2,200 & 4,900 & 8,450 & 12,350 \\
\hline$\ldots \ldots$ & 3,300 & 4,300 & 8,750 & 15,500 & - \\
\hline Cauliflower (trimmed) & 3,900 & 4,500 & 10,100 & 17,700 & 24,650 \\
\hline Celery . . . . . . . . & 1,600 & 2,400 & 8,200 & 14,200 & - \\
\hline \multicolumn{6}{|l|}{ Cherries: } \\
\hline Sour . . . . . . . . . . & 2,100 & 2,850 & 8,500 & 9,800 & 13,650 \\
\hline Sweet $\ldots \ldots \ldots \ldots$ & 1,050 & 2,600 & 7,700 & - & - \\
\hline Corn (sweet) . . . . . . & 8,950 & 13,850 & 35,850 & 63,700 & 78,900 \\
\hline Cranberries ......... & 650 & 950 & - & 3,200 & - \\
\hline Cucumbers & - & - & 5,300 & 6,850 & 8,050 \\
\hline \multicolumn{6}{|l|}{$\begin{array}{l}\text { Endive and Escarole } \\
\text { (see Leaf lettuce) }\end{array}$} \\
\hline Figs (fresh) $\ldots \ldots \ldots$ & - & 2,650 & 12,350 & 16,700 & 21,000 \\
\hline Gooseberries ........ & 1,700 & 2,850 & 5,950 & - & - \\
\hline Grapefruit . ......... & - & 1,000 & 3,100 & 4,250 & - \\
\hline \multicolumn{6}{|l|}{ Grapes: } \\
\hline American .......... & 600 & 1,200 & 3,500 & 7,200 & 8,500 \\
\hline European ......... & 400 & 1,000 & 2,400 & - & 6,050 \\
\hline Kale (whole leaves) .. & 4,700 & 8,900 & 30,250 & 46,900 & - \\
\hline Leeks $\ldots \ldots \ldots \ldots$ & 2,900 & 5,350 & 21,950 & - & 24,850 \\
\hline Lemons . . . . . . . . & 700 & 1,250 & 3,650 & 4,850 & 5,350 \\
\hline \multicolumn{6}{|l|}{ Lettuce: } \\
\hline Head. & 2,500 & 3,650 & 8,450 & 12,200 & 18,100 \\
\hline Leaf. ... & 5,100 & 6,450 & 13,800 & 22,100 & 32,200 \\
\hline Limes $\ldots \ldots \ldots \ldots \ldots$ & - & 800 & 1,800 & 2,800 & 6,650 \\
\hline Mangoes ............ & - & 3,500 & 9,900 & 24,900 & 26,400 \\
\hline
\end{tabular}


Btu per ton per 24 hours

\begin{tabular}{|c|c|c|c|c|c|}
\hline & $32^{\circ} \mathrm{F}$ & $40^{\circ} \mathrm{F}$ & $60^{\circ} \mathrm{F}$ & $7^{\circ} \mathrm{F}$ & $80^{\circ} \mathrm{F}$ \\
\hline \multicolumn{6}{|l|}{ Melons: } \\
\hline Cantaloupes ....... & 1,200 & 2,050 & 7,950 & 12,000 & 14,700 \\
\hline Honeydew . . . . . . & - & 900 & 3,050 & 5,150 & 6,700 \\
\hline Watermelons ..... & - & 800 & - & 4,650 & - \\
\hline Mushrooms ........ & 7,900 & 15,600 & 46,000 & 63,800 & - \\
\hline \multicolumn{6}{|l|}{ Nectarines (see } \\
\hline Okra $\ldots \ldots \ldots \ldots$ & - & 12,250 & 32,050 & 57,400 & 75,900 \\
\hline \multicolumn{6}{|l|}{ Onions: } \\
\hline Dry & 650 & 750 & 2,400 & 3,650 & 6,200 \\
\hline Green . . . . . . . & 3,600 & 9,400 & 17,950 & 25,800 & 33,800 \\
\hline Oranges .......... & 750 & 1,200 & 4,000 & 6,200 & 7,150 \\
\hline Parsnips $\ldots \ldots \ldots \ldots$ & 3,000 & 2,900 & 8,250 & - & - \\
\hline Peaches .......... & 1,150 & 1,700 & 8,300 & 17,750 & 22,350 \\
\hline \multicolumn{6}{|l|}{ Pears: } \\
\hline Bartlett . . . . . . . & 1,100 & 1,650 & 8,250 & 11,000 & - \\
\hline Kieffer . . . . . . . & 450 & - & 3,850 & 4,750 & 5,300 \\
\hline \multicolumn{6}{|l|}{ Peas: } \\
\hline (green, in the pod) .. & 8,500 & 14,450 & 41,900 & 66,750 & 79,200 \\
\hline Peppers (sweet) .... & - & 2,900 & 8,500 & 9,650 & 12,100 \\
\hline Pineapples . . . . . . . . & - & 400 & 3,450 & 7,050 & 10,800 \\
\hline \multicolumn{6}{|l|}{ Plums (including } \\
\hline fresh Prunes) $\ldots$. & 550 & 1,450 & 2,700 & 4,700 & 10,900 \\
\hline \multicolumn{6}{|l|}{ Potatoes: } \\
\hline Uncured . . . . . . . & - & 2,600 & 4,850 & 6,950 & - \\
\hline Cured $\ldots \ldots \ldots$ & - & 1,250 & 1,950 & 2,650 & - \\
\hline \multicolumn{6}{|l|}{ Prunes (see Plums) } \\
\hline Radishes (topped) . . . . & 1,400 & 2,100 & 7,100 & 11,250 & 16,400 \\
\hline Raspberries ........ & 4,700 & 7,650 & 20,200 & - & - \\
\hline \multicolumn{6}{|l|}{ Rhubarb (without } \\
\hline leaves) ....... & 2,350 & 3,200 & 8,700 & 10,650 & - \\
\hline Romaine ......... & - & 4,550 & 9,750 & 15,100 & 23,850 \\
\hline Spinach . . . . . . . . & 4,550 & 10,150 & 39,350 & 50,550 & - \\
\hline \multicolumn{6}{|l|}{ Squash: } \\
\hline Butternut $\ldots \ldots \ldots$ & - & - & - & - & 20,650 \\
\hline \multicolumn{6}{|l|}{ Yellow straight- } \\
\hline Strawberries $\ldots \ldots \ldots$ & $\begin{array}{l}2,100 \\
3,300\end{array}$ & $\begin{array}{l}3,600 \\
5,450\end{array}$ & $\begin{array}{l}18,250 \\
17,950\end{array}$ & $\begin{array}{l}20,050 \\
32,800\end{array}$ & $41 . \overline{800}$ \\
\hline \multicolumn{6}{|l|}{ Sweet potatoes: } \\
\hline Cured .......... & - & - & 4,800 & - & - \\
\hline Uncured . . . . . . . & - & - & 6,300 & - & 14,000 \\
\hline
\end{tabular}




\begin{tabular}{|c|c|c|c|c|c|}
\hline \multirow[t]{2}{*}{ Commodity } & \multicolumn{5}{|c|}{ Btu per ton per 24 hours } \\
\hline & $32^{\circ} \mathrm{F}$ & $40^{\circ} \mathrm{F}$ & $60^{\circ} \mathrm{F}$ & ${70^{\circ}}^{\circ} \mathrm{F}$ & $80^{\circ} \mathrm{F}$ \\
\hline \multicolumn{6}{|l|}{ Tomatoes: } \\
\hline Mature-green ...... & - & 1,450 & 4,900 & 7,650 & 9,400 \\
\hline Pink . . . . . . . . & - & 1,300 & 5,850 & 7,500 & 9,050 \\
\hline Turnips . . . . . . . . & 1,900 & 2,150 & 5,000 & 5,400 & 一 \\
\hline Watercress $\ldots . . \ldots$. & 5,050 & 10,150 & 40,700 & - & 一 \\
\hline
\end{tabular}

*Source: USDA Handbook No. 66, 1968

\section{Sample Refrigeration Requirement Calculation ${ }^{1}$}

Assume that a trailer is loaded with plums in 30-pound fiberboard boxes:

$\operatorname{Load}=$

Net wt. of fruit $=$

Total pounds $=$

Net wt. of boxes $=$

Total pounds $=$

Sp. ht. of the fruit $=$

Sp. ht. box $=$

\section{1,200 boxes}

30 pounds per box

36,000 pounds total (18 tons)

2 pounds each

2,400 pounds total

$0.88 \mathrm{Btu} / \mathrm{lb} /{ }^{\circ} \mathrm{F}$ (table I-1)

$0.44 \mathrm{Btu} / \mathrm{lb} /{ }^{\circ} \mathrm{F} 2$

1. Refrigeration needed to remove the remaining field heat in load:

Assumptions:

Loading temperature $=\mathrm{T}_{1}=52^{\circ} \mathrm{F}$

Desired transit temperature $=\mathrm{T}_{2}=32^{\circ} \mathrm{F}$

Temperature differential $=\mathrm{T}_{1}-\mathrm{T}_{2}=\mathrm{TD}=52^{\circ}-32^{\circ}=20^{\circ}$

then,

Field heat $\left(\mathrm{H}_{\mathrm{f}}\right)=$ WT. X Sp. ht. X TD

$\mathrm{H}_{\mathrm{f}}$ product $=36,000 \mathrm{lb} \times 0.88 \times 20^{\circ}=633,600 \mathrm{Btu}$

$\mathrm{H}_{\mathrm{f}}$ boxes $=2,400 \mathrm{lb} \times 0.40 \times 20^{\circ}=19,200 \mathrm{Btu}$

Total field heat $=633,600+19,200=652,800 \mathrm{Btu}$ 


\section{Transit refrigeration requirement for the heat of respiration:}

Assumptions:

If loading temperature $=52^{\circ}$ and arrival temperature $=32^{\circ} \mathrm{F}$.

then,

Average temperature of product during transit $=40^{\circ} \mathrm{F}$.

Transit time $=3$ days

then,

Heat of respiration $\left(\mathrm{H}_{\mathrm{r}}\right)=$ Respiration rate at average transit temperature ${ }^{2}$

$\mathrm{X}$ time (days) $\mathrm{X}$ wt. (tons)

$\mathrm{H}_{\mathrm{r}}=1,450 \times 3 \times 18=78,300 \mathrm{Btu}$

\section{Refrigeration needed for heat leakage through the trailer body:}

Assumptions:

A 48 -foot trailer with a Ua factor $=140 \mathrm{Btu} /{ }^{\circ} \mathrm{F} / \mathrm{hr}$.

Average outside air temperature $=\mathrm{T}_{1}=75^{\circ} \mathrm{F}$

Thermostat setting $=\mathrm{T}_{2}=34^{\circ} \mathrm{F}^{4}$

Temperature differential $=\mathrm{TD}=\mathrm{T}_{1}-\mathrm{T}_{2}=75^{\circ} \mathrm{F}-34^{\circ} \mathrm{F}=41^{\circ} \mathrm{F}$

thus,

Heat leakage $\left(\mathrm{H}_{1}\right)=$ Ua X TD (avg. outside air - thermostat setting) X time (hours) = Btu $\mathrm{H}_{1}=140 \times 41 \times 72=413,280 \mathrm{Btu}$

4. To get the total number of Btu's the refrigeration must remove in 3 days:

$\mathrm{H}_{\mathrm{f}}+\mathrm{H}_{\mathrm{r}}+\mathrm{H}_{1}=652,800+78,300+413,280=1,144,380 \mathrm{Btu}$

\section{To determine the amount of refrigeration or refrigerant needed:}

Mechanical capacity needed $=1,144,380$ Btu $/ 72$ hrs. = 15,894 Btu hr.

Ice $=$ total pounds needed for 3-day trip $=1,144,380 \mathrm{Btu} / 144^{5}=7,947 \mathrm{lb}$

Liquid nitrogen $\left(\mathrm{N}_{2}\right)=$ total pounds needed for 3-day trip $=1,144,380 \mathrm{Btu} / 175^{6}=6,539 \mathrm{lb}$

\footnotetext{
1 This calculation does not take into account the following factors: (1) the amount of refrigeration needed to precool the vehicle body; (2) air inside the vehicle; and (3) refrigeration needed to counteract air leakage around doors and other places in the body.

2 This figure approximates the specific heat of most wood and fiberboard containers.

3 See table I-2, plums at $40^{\circ} \mathrm{F}$

${ }^{4}$ For products with a desired transport temperature near $32^{\circ} \mathrm{F}$, the thermostat should be set several degrees higher to decrease the chance of freezing damage.

${ }^{5}$ One pound of ice will absorb 144 Btu's of heat.

${ }^{6}$ One pound of liquid nitrogen will absorb approximately $175 \mathrm{Btu}$ 's of heat at temperatures above $32^{\circ} \mathrm{F}$.
} 


\section{Appendix II}

\section{Load Compatibility Groups ${ }^{1}$}

\section{Group 1}

- Apples

- Apricots

- Berries (except cranberries)

- Cherries

- Figs (not with apples, danger of odor transfer to figs; also see group 6a)

- Grapes $^{2}$ (see groups 2 and 6a)

- Peaches

- Pears

- Persimmons

- Plums and prunes

- Pomegranates

- Quinces

\section{Recommended Transit Conditions:}

- Temperature:

$32^{\circ}$ to $34^{\circ} \mathrm{F}\left(0^{\circ}\right.$ to $\left.1.5^{\circ} \mathrm{C}\right)$

- Relative humidity:

90 to 95 percent

- Atmosphere:

Normally used on berries and cherries only-10 to 20 percent $\mathrm{CO}_{2}$

- Ice:

Never in contact with commodity.

Note: Most members of this group are not compatible with group $6 \mathrm{a}$ or $6 \mathrm{~b}$ because ethylene production by group 1 can be high, and thus harmful to members of group $6 \mathrm{a}$ or $6 \mathrm{~b}$.

${ }^{1}$ Taken from USDA Marketing Research Report No. 1070, "Compatibility of Fruits and Vegetables During Transport in Mixed Loads," by W. J. Lipton and J. M. Harvey, 1977.

${ }^{2}$ Grapes: Compatible with other commodities only if the grapes are not fumigated with sulfur dioxide $\left(\mathrm{SO}_{2}\right)$ in vehicle and if no chemicals that release $\mathrm{SO}_{2}$ are included in packages.

\section{Group 2}

- Avocados

- Bananas 
- Eggplants (also see group 5)

- Grapefruit ${ }^{3}$

- Guava

- Limes

- Mangoes

- Muskmelons, other than cantaloupes

Casaba

Crenshaw

Honey Dew

Persian

- Olives, fresh

- Papayas

- Pineapples (not with avocados, danger of avocados' odor absorption)

- Tomatoes, green

- Tomatoes, pink (also see group 4)

- Watermelons (also see groups 4 and 5)

\section{Recommended Transit Conditions:}

- Temperature:

$55^{\circ}$ to $65^{\circ} \mathrm{F}\left(13^{\circ}\right.$ to $\left.18^{\circ} \mathrm{C}\right)$

- Relative humidity:

85 to 95 percent

- Ice:

Never in contact with commodity

${ }^{3}$ Citrus Fruits : Oranges and tangerines-compatibility depends on source. Florida- or Texas-grown oranges are shipped at $32^{\circ}$ to $34^{\circ} \mathrm{F}\left(0.0^{\circ}\right.$ to $\left.1.1^{\circ} \mathrm{C}\right)$, but oranges grown in California and Arizona are shipped at $38^{\circ}$ to $48^{\circ} \mathrm{F}\left(3.3^{\circ}\right.$ to $\left.8.8^{\circ} \mathrm{C}\right)$.

\section{Group 3}

- Cantaloupes

- Cranberries

- Lemons (adjust temperature to other commodity)

- Lychees (also see group 4)

- Oranges

- Tangerines

\section{Recommended Transit Conditions:}

- Temperature:

$36^{\circ}$ to $41^{\circ} \mathrm{F}\left(2.5^{\circ}\right.$ to $\left.5.0^{\circ} \mathrm{C}\right)$

- Relative humidity:

90 to 95 percent; cantaloupes about 95 percent

- Ice:

In contact only with cantaloupes 


\section{Group 4}

- Beans, snap

- Lychees (also see group 3)

- Okra

- Peppers, green (not with beans)

- Peppers, red (if with green peppers, temperature adjusted toward top of range)

- Squash, summer

- Tomatoes, pink (also see group 2)

- Watermelons (also see groups 2 and 5)

\section{Recommended Transit Conditions:}

- Temperature:

$40^{\circ}$ to $45^{\circ} \mathrm{F}\left(4.5^{\circ}\right.$ to $\left.7.5^{\circ} \mathrm{C}\right)$

- Relative humidity:

About 95 percent

- Ice:

Never in contact with commodity

\section{Group 5}

- Cucumbers

- Eggplants (also see group 2)

- Ginger (not with eggplants, also see group 7)

- Grapefruit, Florida (after January 1), and Texas

- Potatoes (late crop)

- Pumpkin and squashes, winter

- Watermelons (temperature adjusted for other members of groups; also see groups 2 and 4)

\section{Recommended Transit Conditions:}

- Temperature:

$40^{\circ}$ to $55^{\circ} \mathrm{F}\left(4.4^{\circ}\right.$ to $\left.13^{\circ} \mathrm{C}\right)$; ginger not below $55^{\circ} \mathrm{F}$

- Relative humidity:

85 to 90 percent

- Ice:

Never in contact with commodity 


\section{Group 6a}

- Artichokes

- Asparagus

- Beets, red

- Carrots

- Endive and escarole

- Figs (also see group 1)

- Grapes (also see group 1)

- Greens

- Leeks (not with figs or grapes)

- Lettuce

- Mushrooms

- Parsley

- Parsnips

- Peas

- Rhubarb

- Salsify

- Spinach

- Sweet corn

- Watercress

This group, except for figs, grapes, and mushrooms, is compatible with group $6 \mathrm{~b}$.

\section{Recommended Transit Conditions:}

- Temperature:

$32^{\circ}$ to $34^{\circ} \mathrm{F}\left(0^{\circ}\right.$ to $\left.1.1^{\circ} \mathrm{C}\right)$

- Relative humidity:

95 to 100 percent

- Ice:

Never in contact with asparagus, figs, grapes, or mushrooms

\section{Group 6b}

- Broccoli

- Brussels sprouts

- Cabbage

- Cauliflower

- Celeriac

- Horseradish

- Kohlrabi

- Onions, green (not with rhubarb, figs, grapes, mushrooms, or sweet corn)

- Radishes

- Rutabagas

- Turnips

This group is compatible with group 6a, except for figs, grapes, and mushrooms. 


\section{Recommended Transit Conditions:}

- Temperature:

$32^{\circ}$ to $34^{\circ} \mathrm{F}\left(0^{\circ}\right.$ to $\left.1.1^{\circ} \mathrm{C}\right)$

- Relative humidity:

95 to 100 percent

- Ice:

Contact acceptable for all

\section{Group 7}

- Ginger (also see group 5)

- Potatoes, early crop (temperatures adjusted for others)

- Sweet potatoes

\section{Recommended Transit Conditions:}

- Temperature:

$55^{\circ}$ to $65^{\circ} \mathrm{F}\left(13^{\circ}\right.$ to $\left.18^{\circ} \mathrm{C}\right)$

- Relative humidity:

85 to 90 percent

- Ice:

Never in contact with commodity

\section{Group 8}

- Garlic

- Onions, dry

Recommended Transit Conditions:

- Temperature:

$32^{\circ}$ to $34^{\circ} \mathrm{F}\left(0^{\circ}\right.$ to $\left.1.5^{\circ} \mathrm{C}\right)$

- Relative humidity:

65 to 75 percent

- Ice:

Never in contact with commodity 
Table III-1.-Recommended Protective Services for Perishable Foods During Transit

\begin{tabular}{ccccc}
\hline Recommended & Transit \\
Temperature & $\begin{array}{c}\text { Desired } \\
\text { Relative } \\
\text { Humidity }\end{array}$ & $\begin{array}{c}\text { Highest } \\
\text { Freezing } \\
\text { Point }\end{array}$ & $\begin{array}{c}\text { Top-ice } \\
\text { and/or } \\
\text { Package-ice } \\
\text { OK }\end{array}$ \\
\hline & & &
\end{tabular}

Fresh fruits and

Percent $\quad{ }^{\circ} \mathrm{F} \quad{ }^{\circ} \mathrm{C}$

vegetables:

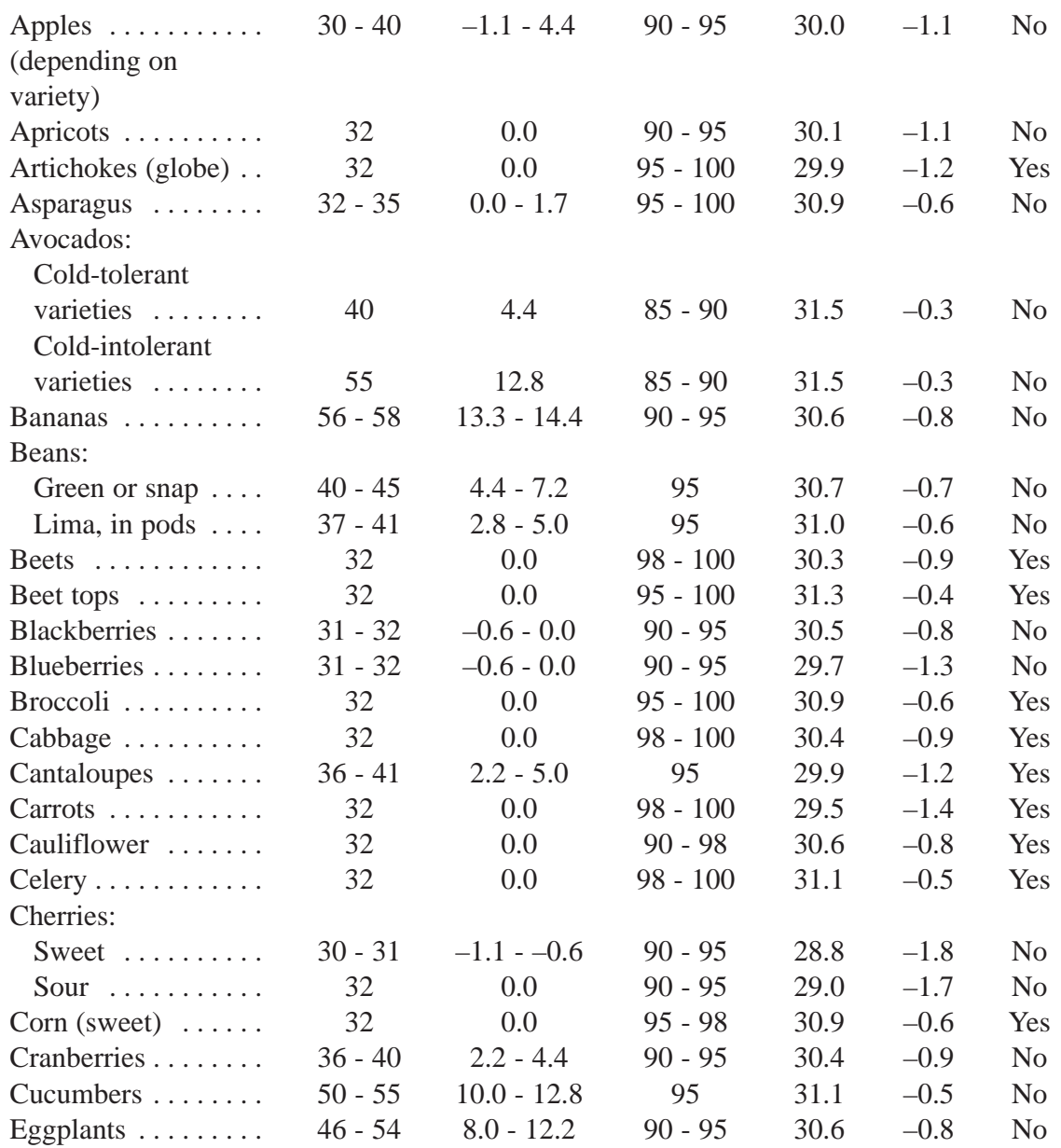




\begin{tabular}{|c|c|c|c|c|}
\hline Product & $\begin{array}{c}\text { Recommended } \\
\text { Transit } \\
\text { Temperature }\end{array}$ & $\begin{array}{l}\text { Desired } \\
\text { Relative } \\
\text { Humidity }\end{array}$ & $\begin{array}{c}\text { Highest } \\
\text { Freezing } \\
\text { Point }\end{array}$ & $\begin{array}{c}\text { Top-ice } \\
\text { and/or }{ }^{1} \\
\text { Package-ice } \\
\text { OK }\end{array}$ \\
\hline
\end{tabular}

Fresh fruits and

vegetables: - Continued

\begin{tabular}{|c|c|c|c|c|c|c|}
\hline Endive (escarole) ... & 32 & 0.0 & $90-95$ & 31.9 & -0.1 & Yes \\
\hline Garlic (dry) . . . . . & $32-34$ & $0.0-1.1$ & $65-75$ & 30.5 & -0.8 & No \\
\hline \multicolumn{7}{|l|}{ Grapefruit: } \\
\hline \multicolumn{7}{|l|}{ Arizona and } \\
\hline California & $58-60$ & $14.0-15.6$ & $85-90$ & 30.0 & -1.1 & No \\
\hline Florida and Texas & $50-60$ & $10.0-15.6$ & $85-90$ & 30.0 & -1.1 & Jo \\
\hline \multicolumn{7}{|l|}{ Grapes: } \\
\hline American type ... & 32 & 0.0 & 85 & 29.7 & -1.3 & No \\
\hline \multicolumn{7}{|l|}{ European type } \\
\hline (Vinifera) ..... & $30-31$ & $-1.1--0.6$ & $90-95$ & 28.1 & -2.2 & No \\
\hline Kale ........... & 32 & 0.0 & $95-100$ & 31.1 & -0.5 & Co \\
\hline Kiwi Fruit & 32 & 0.0 & $90-95$ & 29.0 & -1.7 & $\sqrt{0}$ \\
\hline Lemons .. & $45-55$ & $7.2-12.8$ & $85-90$ & 29.4 & -1.4 & No \\
\hline Lettuce . & 32 & 0.0 & $98-100$ & 31.7 & -0.2 & 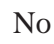 \\
\hline Limes . . . . . . . . . & $48-50$ & $8.9-10.0$ & $85-90$ & 29.1 & -1.6 & No \\
\hline Mangoes & 55 & 12.8 & $85-90$ & 30.3 & -0.9 & \\
\hline
\end{tabular}

Melons:

Honeydew, Casaba,

Crenshaw, and

Persian ........

\begin{tabular}{|c|c|c|c|c|}
\hline $45-50$ & $7.2-10.0$ & $90-95$ & 30.5 & -0.8 \\
\hline 32 & 0.0 & 95 & 30.4 & -0.9 \\
\hline $45-50$ & $7.2-10.0$ & $90-95$ & 28.7 & -1.8 \\
\hline 32 & 0.0 & $65-70$ & 30.6 & -0.8 \\
\hline 32 & 0.0 & $95-100$ & 30.4 & -0.9 \\
\hline 32 & 0.0 & $95-100$ & 31.6 & -0.2 \\
\hline 32 & 0.0 & $95-100$ & 30.7 & -0.7 \\
\hline \multirow[t]{4}{*}{$32-48$} & $0.0-8.8$ & $85-90$ & 30.6 & -0.8 \\
\hline & & & \multicolumn{2}{|c|}{ (flesh) } \\
\hline & & & 29.7 & -1.3 \\
\hline & & & & \\
\hline
\end{tabular}

Parsley ........ 32

Parsnips ........ 32

0.0

$95-100$

$30.0 \quad-1.1 \quad$ Yes

0.0

$98-100$

30.4

-0.9 Yes

Peaches and

Nectarines ......

Pears $^{3}$

$\begin{array}{ll}-0.9 & \text { No } \\ -1.6 & \text { No }\end{array}$




\begin{tabular}{lcccc}
\hline Recommended & Desired \\
Transit & Temperature & $\begin{array}{c}\text { Highest } \\
\text { Relative } \\
\text { Humidity }\end{array}$ & $\begin{array}{c}\text { Top-ice } \\
\text { and/or } 1 \\
\text { Freezing } \\
\text { Point }\end{array}$ & $\begin{array}{c}\text { Package-ice } \\
\text { OK }\end{array}$ \\
\hline
\end{tabular}

Fresh fruits and

${ }^{\circ} \mathrm{F} \quad \quad{ }^{\circ} \mathrm{C} \quad$ Percent $\quad{ }^{\circ} \mathrm{F} \quad{ }^{\circ} \mathrm{C}$

vegetables: - Continued

Peas:

(green, in pods) . . $\quad 32$

0.0

$95-98$

$30.9 \quad-0.6 \quad$ Yes
(pods)

...............

$29.9-1.2$

(shelled)

Peppers (sweet) $45-55 \quad 7.2-12.8$

$90-95$

$30.7-0.7$

No

Pineapples:

Mature-green ....

$50-55$

45

$10.0-13.0$

$85-90$

7.2

$85-90$

30.

Ripe Fruit ........

Plums and Fresh

Prunes .........

0.0

$90-95$

30.5

$-1.1 \quad$ No

$30.0 \quad-1.1 \quad$ No

Potatoes:

Early crop for table ....... $50-60 \quad 10.0-15.6$

90

$30.9 \quad-0.6 \quad$ No

Early crop for chipping ......

$65-70 \quad 18.3-21.1$

90

$30.9-0.6 \quad$ No

Late crop for table .........

$40-50 \quad 4.4-10.0$

90

30.

Late crop for chipping ......

$$
50-60
$$

$10.0-15.6$

32

32

0.0

Radishes .
Raspberries

0.0

90
$95-100$
$90-95$

30.9

30.7

$-0$

$-0.7$

30.

(black)

30.9 (red) $^{-0.6}$

Rhubarb ........ 32

Romaine ........ $\quad 32$

0.0

Salad mixes ...... 33

Spinach ........ 32

0.0

0.6

0.0

$95-100$

95

$90-95$

$95-100$

$30.3-0.9$

$31.7-0.2$

(varies)

$31.5-0.3$

No

Squash and

Pumpkins:

Winter

Summer ......

$$
50-55
$$

$41-50$

$10.0-12.8$

$50-70$

30.5

95

31.1

$-0.8$

$-0.5$

No

$\begin{array}{lc}\text { Strawberries ....... } & 32 \\ \text { Sweet potatoes ..... } & 55-60\end{array}$

0.0

40

$12.8-15.6$

4.4

$90-95$

30.

29.

Tangerines ........

$85-90$

$-0.8 \quad$ No

$90-95$

30.

$-1.3 \quad$ No




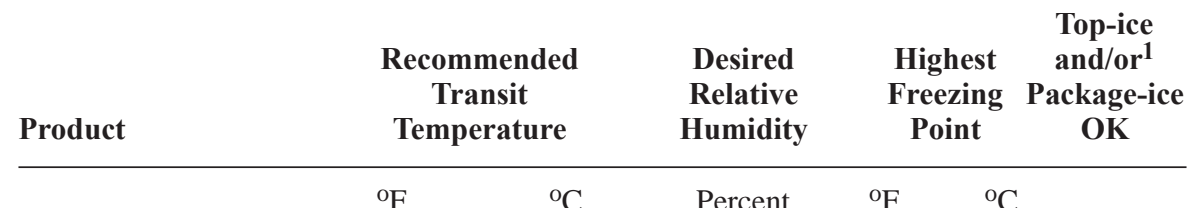

Fresh fruits and

vegetables: - Continued

Tomatoes:

$\begin{array}{rcccccc}\text { Mature-green } \ldots \ldots & 55-70 & 12.8-21.1 & 90-95 & 31.0 & -0.6 & \text { No } \\ \text { Pink .......... } & 46-50 & 7.2-10.0 & 90-95 & 31.1 & -0.5 & \text { No } \\ \text { Watermelons } \ldots \ldots & 50-60 & 10.0-15.6 & 90 & 31.3 & -0.4 & \text { No } \\ \text { Canned Foods }^{4} \ldots & - & - & - & - & - & -\end{array}$

Dairy Products:

Butter:

\begin{tabular}{|c|c|c|c|c|c|}
\hline$\ldots \ldots$ & 39 & 3.9 & $75-85$ & & \\
\hline Frozen ........ & -10 & -23.3 & & & \\
\hline Iargarine & 35 & 1.7 & $60-70$ & & \\
\hline Filk (whole) & $32-34$ & $0.0-1.1$ & & 31.0 & -0.6 \\
\hline heese $^{5} \ldots$ & $34-40$ & $1.0-4.0$ & $65-70$ & & \\
\hline e Cream & $-20--15$ & $-29--26$ & 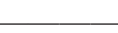 & 21.0 & -6.0 \\
\hline
\end{tabular}

Fresh and Cured Meat and

Seafood $^{6} \ldots . .$.

Frozen Foods ${ }^{7} \ldots$. .

Poultry and Eggs:

$\begin{array}{lcccccc}\text { Fresh } \ldots \ldots \ldots \ldots & 26-34 & -3.0-1.1 & 90-95 & 27.0 & -2.8 & \text { Yes } \\ \text { Hard, chilled .... } & 0-26 & -18--3 & 90-95 & 27.0 & -2.8 & \text { No } \\ \text { Eggs } \ldots \ldots \ldots \ldots & 40-45 & 4.4-7.2 & 80-85 & 28.0 & -2.2 & \text { No }\end{array}$

\footnotetext{
${ }^{1}$ Make sure products are packed in moisture resistant containers before applying top- or package-ice.

${ }^{2}$ Florida and Texas oranges shipped from cold storage or those that will be in transit for more than 5 days should be held at $32-34^{\circ} \mathrm{F}\left(0.0^{\circ}\right.$ to $\left.1.1^{\circ} \mathrm{C}\right)$. Arizona and California oranges should be shipped at $38^{\circ}$ to $48^{\circ} \mathrm{F}$.

${ }^{3}$ Early Bartlett pears that are ripened in transit should be shipped at $55-60^{\circ} \mathrm{F}$.

${ }^{4}$ See text page 57 and table 4.

5 See text page 60 and table 5 .

${ }^{6}$ See text page 62 and table 6 .

${ }^{7}$ All frozen foods should be shipped at $0^{\circ} \mathrm{F}\left(-18^{\circ} \mathrm{C}\right)$ or below.
} 


\section{Selected Bibliography}

American Society of Heating, Refrigerating, and Air-Conditioning Engineers, ASHRAE Handbook-Refrigeration Systems and Applications, Atlanta, GA, various editions.

Ashby, et al., User's Guide to the RTF Truck Trailer Classification, Transportation Tips No. 8, AMS-TMD, U.S. Department of Agriculture, Washington, DC, March 1989.

Frozen Food Roundtable, Frozen Food Handling and Merchandising-A Code of Recommended Practices, Washington, DC, 1992.

Hardenburg, R.E., et al. The Commercial Storage of Fruits, Vegetables, and Florist and Nursery Stocks, Agricultural Handbook No. 66, ARS, U.S. Department of Agriculture, Washington, DC, 1986.

Kasmire, R.F. and R. Tom Hinsch, Maintaining Optimum Transit Temperatures in Refrigerated Truck Shipments, University of California Perishables Handling Supplement No. 2, University of California, Davis, CA 95616, and ARS, U.S. Department of Agriculture, Fresno, CA, April 1987.

Lipton, W.J. and John M. Harvey, Compatibility of Fruits and Vegetables During Transport in Mixed Loads, MRR-1070, ARS, U.S. Department of Agriculture, Washington DC, May 1977.

McGregor, Brian M., Tropical Products Transport Handbook, Agricultural Handbook No. 668, U.S. Department of Agriculture, Washington, DC, 1987.

Nicholas, C.J., Export Handbook for U.S. Agriculture Products, Agricultural Handbook No. 593, U.S. Department of Agriculture, Washington, DC, March 1985.

The Packer, Produce Availability \& Merchandising Guide, Vance Publishing Corp., Overland Park, KS, 1993.

The Refrigeration Research Foundation, Commodity Storage Manual, International Association of Refrigerated Warehouses, Bethesda, MD.

Transfresh, Fresh Produce Mixer \& Loading Guide, Transfresh Corp., Salinas, CA, 1988. 


\section{Other Resources}

Contact the Refrigerated Transportation Library, Department of Pomology, Wickson Hall, University of California, Davis, CA 95616, for a catalog of videos, slide sets, and printed material that may be either purchased or obtained free. The items in the catalog are of interest to those involved in the transportation of perishable foods. It comprises the library of the Refrigerated Transportation Foundation and other resources available from the University of California, Davis, Cooperative Extension and the U.S. Department of Agriculture.

\section{Preferred Citation}

Ashby, B. Hunt. Protecting Perishable Foods During Transport by Truck.

U.S. Department of Agriculture, Agricultural Marketing Service, September 1995, reprinted July 2006. Web. <http://dx.doi.org/10.9752/TS024.07-2006> 